- Prepared in cooperation with the National Park Service

Etfects of Glmate and land Use Change on Thermal Springs

Becharge $\rightarrow$ Sy stem Based Coupled Surface-Waterand Goundwater Fi ow Morte for HotSpings National Palk

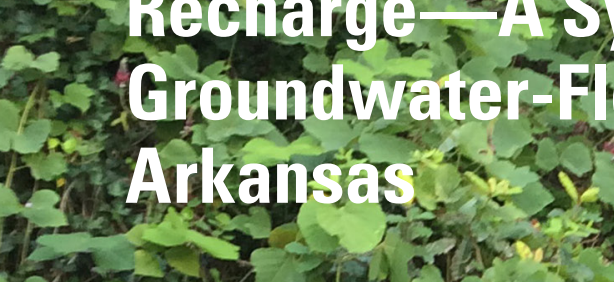

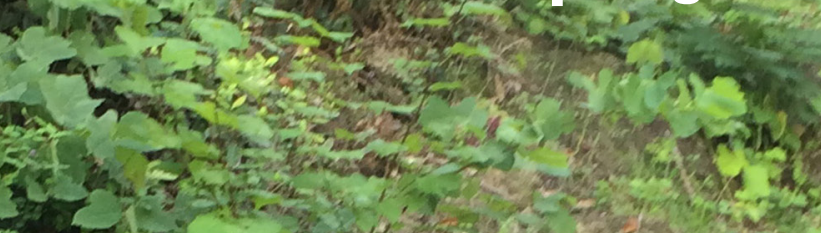

and
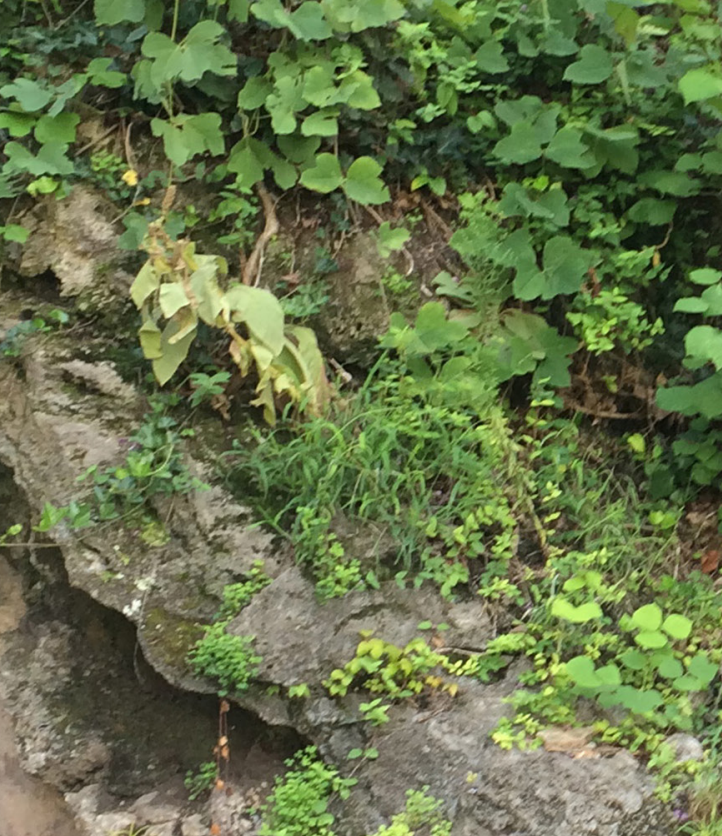

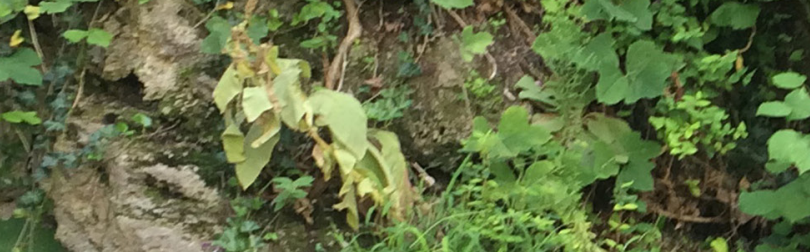
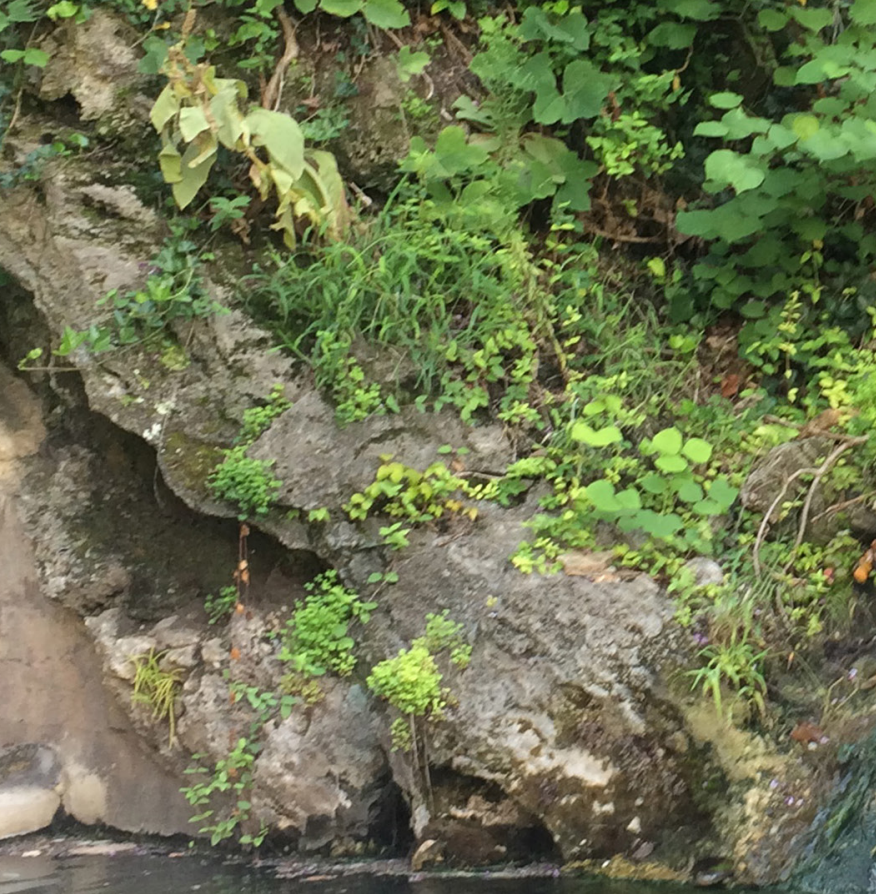

$$
\text { vith }
$$

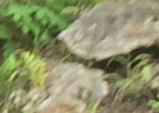

Scientific Investigations Report 2021-5045

U.S. Department of the Interior U.S. Geological Survey 
Cover. Photograph showing a spring at Hot Springs, Arkansas. 


\section{Effects of Climate and Land-Use Change on Thermal Springs Recharge-A System-Based Coupled Surface-Water and Groundwater-Flow Model for Hot Springs National Park, Arkansas}

By Rheannon M. Hart, Scott J. Ikard, Phillip D. Hays, and Brian R. Clark

Prepared in cooperation with the National Park Service

Scientific Investigations Report 2021-5045 


\section{U.S. Geological Survey, Reston, Virginia: 2021}

For more information on the USGS - the Federal source for science about the Earth, its natural and living resources, natural hazards, and the environment—visit https://www.usgs.gov or call 1-888-ASK-USGS.

For an overview of USGS information products, including maps, imagery, and publications, visit https://store.usgs.gov/.

Any use of trade, firm, or product names is for descriptive purposes only and does not imply endorsement by the U.S. Government.

Although this information product, for the most part, is in the public domain, it also may contain copyrighted materials as noted in the text. Permission to reproduce copyrighted items must be secured from the copyright owner.

Suggested citation:

Hart, R.M., Ikard, S.J., Hays, P.D., and Clark, B.R., 2021, Effects of climate and land-use change on thermal springs recharge-A system-based coupled surface-water and groundwater-flow model for Hot Springs National Park, Arkansas: U.S. Geological Survey Scientific Investigations Report 2021-5045, 38 p., https://doi.org/10.3133/ sir20215045.

Associated data for this publication:

Hart, R.M., and Ikard, S.J., 2021, Model inputs and outputs for simulating and predicting the effects of climate and land-use changes on thermal springs recharge — A system-based coupled surface-water and groundwater-flow model for Hot Springs National Park, Arkansas: U.S. Geological Survey data release, https://doi.org/10.5066/P9SBJVVL.

ISSN 2328-0328 (online) 


\section{Acknowledgments}

The authors would like to thank the National Park Service for their support in conducting this research. Without their concern and desire to protect and preserve the springs at Hot Springs National Park, this research would have been inessential. The authors would also like to gratefully and sincerely thank Dr. Jeff Connelly, Professor of Structure, Tectonics, and Engineering Geology at the University of Arkansas at Little Rock, for his help with the hydrogeologic framework beneath Hot Springs National Park. Without his generous help, the hydrogeologic framework depicted herein would not have been nearly as detailed or representative. Work on this project was conducted when R.M. Hart was employed by the U.S. Geological Survey. 



\section{Contents}

Acknowledgments ……...................................................................................................................

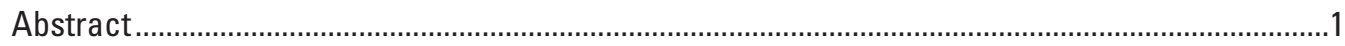

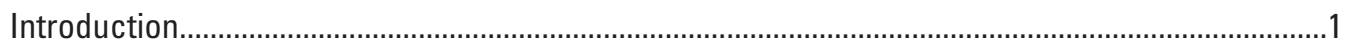

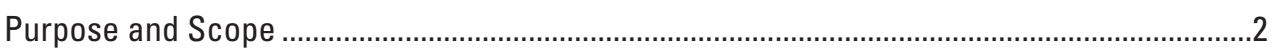

Previous Investigations..........................................................................................................

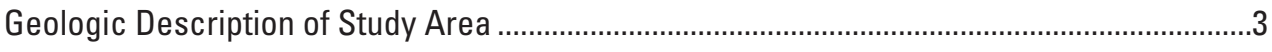

Hydrogeologic Description of Study Area ...........................................................................

Delineation of the Recharge Area .....................................................................................

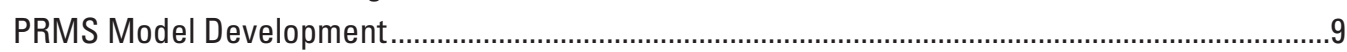

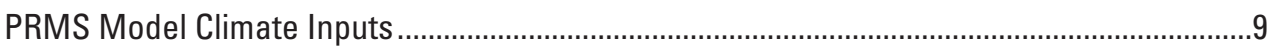

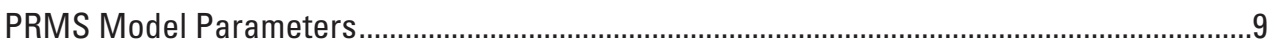

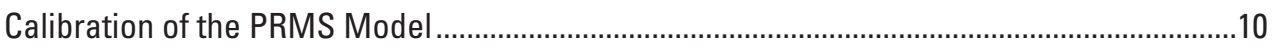

PRMS Model Results ............................................................................................................. 10

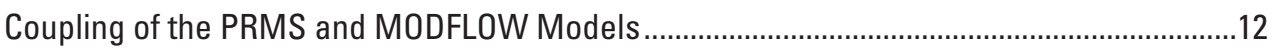

MODFLOW Groundwater-Flow Model Development................................................................13

MODFLOW Model Discretization and Framework …….......................................................13

Boundary Conditions in the MODFLOW Model .....................................................................14

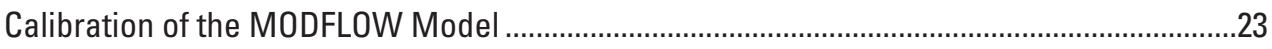

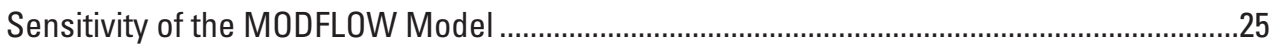

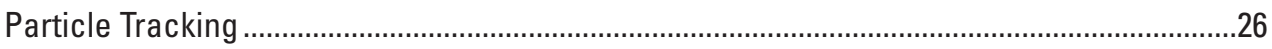

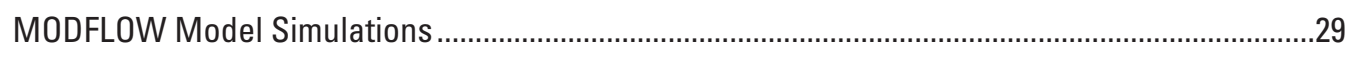

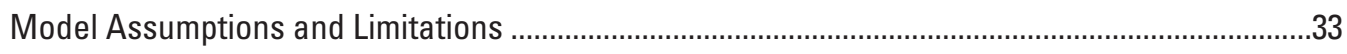

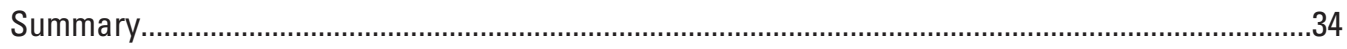

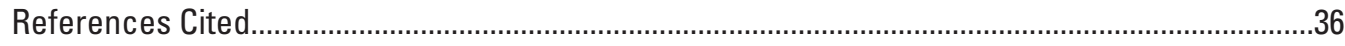

\section{Figures}

1. Map showing the locations of the Gulpha Creek streamgage, Hot Springs thermal springs, Hot Springs watershed and surrounding area streams, hydrologic response units delineating the Precipitation-Runoff Modeling System model boundaries, approximate recharge area, well heads $\mathrm{H} 1-\mathrm{H} 9$, MODFLOW groundwater-flow model boundary, the city of Hot Springs, and the Hot Springs National Park boundary, Arkansas.

2. Map showing the regional surficial geology controlling hydrogeologic processes in Hot Springs National Park with decimated MODFLOW groundwater-flow model grid

3. Map showing locations of formations contributing to the estimated recharge area for the Hot Springs thermal springs and elevations of the recharge area near Hot Springs National Park, Arkansas..

4. Graph showing simulated and measured daily mean streamflow at U.S. Geological Survey streamgage 07358550, Gulpha Creek at Hot Springs, Arkansas, August 14, 2009-December 31, 2014

5. Graph showing annual mean precipitation time series used as

Precipitation-Runoff Modeling System (PRMS) model input, and 
PRMS-simulated annual mean runoff and recharge for the simulation period 1980-2014 for the Hot Springs National Park and surrounding area, Arkansas

6. Map showing Precipitation-Runoff Modeling System-simulated annual mean recharge in individual hydrologic response units for use in the groundwater-flow model of the Hot Springs National Park and surrounding area, Arkansas

7. Map showing recharge simulated by the Hydrologic Evaluation of Landfill Performance v. 3 model for the Hot Springs National Park and surrounding area, Arkansas

8. Map showing annual mean recharge simulated by the Soil-Water-Balance model for the Hot Springs National Park and surrounding area, Arkansas . .18

9. Three-dimensional hydrogeologic framework and model grid of the MODFLOW groundwater-flow model: MODFLOW groundwater-flow model framework showing surficial and subsurface geology, and MODFLOW groundwater-flow model framework showing subsurface geology

10. River network showing cells of the top layer of the model grid used as nonlinear head-dependent flux boundaries for the Hot Springs National Park study area, Arkansas

11. Examples of Precipitation-Runoff Modeling System-simulated recharge applied to the top layer of the MODFLOW model grid for the Hot Springs National Park study area, Arkansas

12. Simplified diagram of the conceptual groundwater-flow path between the recharge location and the thermal springs in the MODFLOW groundwater-flow model, from which the starting heads in each cell of the model grid and the reference heads in the general head boundary cells were computed....

13. Distribution of starting heads in the model grid calculated from equation 12 and derived from the simplified conceptual model of the groundwater-flow system shown in figure 12 for the Hot Springs National Park and surrounding area, Arkansas

14. Sensitivity matrices showing the sensitivity of simulated equivalents to parameter values for the Hot Springs National Park and surrounding area, Arkansas

15. Forward and backward particle-tracking simulations produced from the calibrated MODFLOW groundwater-flow model

16. Simulated heads in the model grid corresponding to the calibration solution for the Hot Springs National Park and surrounding area, Arkansas

17. Graph showing linear relation between recharge supplied to the groundwater-flow system and spring flows simulated by the calibrated model for the Hot Springs National Park study area, Arkansas

\section{Tables}

1. Summary of calibrated values for selected hydrology parameters for the Precipitation-Runoff Modeling System.

2. Summary of model-fit statistics for calibration of the Precipitation-Runoff Modeling System model.

3. Simulated recharge values, obtained by using the Rorabaugh code, for U.S. Geological Survey streamgages near the Hot Springs National Park and surrounding area, Arkansas 
4. Summary of calibrated model parameters by geologic formation in the Hot Springs National Park and surrounding area, Arkansas

5. Summary of hydraulic heads in wells in the Hot Springs National Park and surrounding area, Arkansas

6. Comparison of median values of starting heads and simulated heads by formation in the Hot Springs National Park and surrounding area, Arkansas.

7. Summary of inputs and outputs of water and associated mass balances for Hot Springs National Park MODFLOW groundwater-flow model simulations using PRMS-simulated recharge grids as stresses to the groundwater-flow system

\section{Conversion Factors}

U.S. customary units to International System of Units

\begin{tabular}{|c|c|c|}
\hline Multiply & By & To obtain \\
\hline \multicolumn{3}{|c|}{ Length } \\
\hline inch (in.) & 2.54 & centimeter $(\mathrm{cm})$ \\
\hline inch (in.) & 25.4 & millimeter (mm) \\
\hline foot $(\mathrm{ft})$ & 0.3048 & meter $(\mathrm{m})$ \\
\hline mile (mi) & 1.609 & kilometer (km) \\
\hline yard (yd) & 0.9144 & meter $(\mathrm{m})$ \\
\hline \multicolumn{3}{|c|}{ Area } \\
\hline square mile $\left(\mathrm{mi}^{2}\right)$ & 2.590 & square kilometer $\left(\mathrm{km}^{2}\right)$ \\
\hline \multicolumn{3}{|c|}{ Volume } \\
\hline acre-foot (acre-ft) & 1,233 & cubic meter $\left(\mathrm{m}^{3}\right)$ \\
\hline \multicolumn{3}{|c|}{ Flow rate } \\
\hline foot per second (ft/s) & 0.3048 & meter per second $(\mathrm{m} / \mathrm{s})$ \\
\hline foot per year (ft/yr) & 0.3048 & meter per year (m/yr) \\
\hline cubic foot per second $\left(\mathrm{ft}^{3} / \mathrm{s}\right)$ & 0.02832 & cubic meter per second $\left(\mathrm{m}^{3} / \mathrm{s}\right)$ \\
\hline cubic foot per day $\left(\mathrm{ft}^{3} / \mathrm{d}\right)$ & 0.02832 & cubic meter per day $\left(\mathrm{m}^{3} / \mathrm{d}\right)$ \\
\hline inch per year (in/yr) & 25.4 & millimeter per year (mm/yr) \\
\hline \multicolumn{3}{|c|}{ Pressure } \\
\hline pound per square foot $\left(\mathrm{lb} / \mathrm{ft}^{2}\right)$ & 0.04788 & kilopascal $(\mathrm{kPa})$ \\
\hline \multicolumn{3}{|c|}{ Density } \\
\hline pound per cubic foot $\left(\mathrm{lb} / \mathrm{ft}^{3}\right)$ & 16.02 & kilogram per cubic meter $\left(\mathrm{kg} / \mathrm{m}^{3}\right)$ \\
\hline pound per cubic foot $\left(\mathrm{lb} / \mathrm{ft}^{3}\right)$ & 0.01602 & gram per cubic centimeter $\left(\mathrm{g} / \mathrm{cm}^{3}\right)$ \\
\hline \multicolumn{3}{|c|}{ Transmissivity } \\
\hline foot squared per day $\left(\mathrm{ft}^{2} / \mathrm{d}\right)$ & 0.09290 & meter squared per day $\left(\mathrm{m}^{2} / \mathrm{d}\right)$ \\
\hline
\end{tabular}

Temperature in degrees Celsius $\left({ }^{\circ} \mathrm{C}\right)$ may be converted to degrees Fahrenheit $\left({ }^{\circ} \mathrm{F}\right)$ as follows: ${ }^{\circ} \mathrm{F}=\left(1.8 \times{ }^{\circ} \mathrm{C}\right)+32$. 


\title{
Datum
}

Vertical coordinate information is referenced to the North American Vertical Datum of 1988 (NAVD 88).

Horizontal coordinate information is referenced to the North American Datum of 1983 (NAD 83).

Elevation, as used in this report, refers to distance above the vertical datum.

\section{Supplemental Information}

Concentrations of chemical constituents in water are given in milligrams per liter (mg/L).

\section{Abbreviations}

\author{
CMIP5 Phase 5 Coupled Model Intercomparison Project \\ GCM global climate model \\ GHB general head boundary \\ HELP3 Hydrologic Evaluation of Landfill Performance v. 3 \\ hk horizontal hydraulic conductivity \\ HRU hydrologic response unit \\ PRMS Precipitation-Runoff Modeling System \\ $\mathrm{O}_{\mathrm{s}} \quad$ simulated equivalent spring flows \\ RCP Representative Concentration Pathway \\ $\mathrm{R}^{2} \quad$ coefficient of determination \\ RMSE root mean square error \\ RORA Rorabaugh (model) \\ SSURGO Soil Survey Geographic database (U.S. Department of Agriculture) \\ SWB Soil-Water-Balance (model) \\ TDS total dissolved solids \\ USGS U.S. Geological Survey \\ vka vertical hydraulic conductivity
}




\title{
Effects of Climate and Land-Use Change on Thermal Springs Recharge-A System-Based Coupled Surface-Water and Groundwater-Flow Model for Hot Springs National Park, Arkansas
}

\author{
By Rheannon M. Hart, Scott J. Ikard, Phillip D. Hays, and Brian R. Clark
}

\section{Abstract}

A three-dimensional hydrogeologic framework of the Hot Springs anticlinorium beneath Hot Springs National Park, Arkansas, was constructed to represent the complex hydrogeology of the park and surrounding areas to depths exceeding 9,000 feet below ground surface. The framework, composed of 6 rock formations and 1 vertical fault emplaced beneath the thermal springs, was discretized into 19 layers, 429 rows, and 576 columns and incorporated into a 3-dimensional steady-state groundwater-flow model constructed in MODFLOW-2005. Historical daily mean thermal spring flows were simulated for one stress period of approximately 34 years (1980-2014), chosen to represent the period of record for historical climate data used in the quantification of the boundary conditions. The groundwater-flow model was manually calibrated to historical daily mean thermal spring flows of 88,000 cubic feet per day observed over a 12-year period of record (1990-1995 and 1998-2005) at the thermal springs collection system. Calibration was achieved by calculating starting heads and general head boundary conditions from the Bernoulli equation and then adjusting the horizontal and vertical hydraulic conductivities of the rock formations and vertical fault and the hydraulic conductance of head-dependent flux boundaries. The groundwater-flow model was coupled to a surface-water model developed in the Precipitation-Runoff Modeling System (PRMS) by using PRMS-simulated gravity drainage as a specified flux recharge boundary condition in the groundwater-flow model. Together, the coupled models were used to (1) locate the areas of groundwater recharge to the thermal springs in the discretized hydrogeologic framework by using forward and reverse particle-tracking capabilities of MODPATH, (2) simulate the effects of variable recharge rates on the spring flows at the thermal springs, and (3) assess possible effects of climate and land-use change on the long-term variability of spring flows at the thermal springs.

Forward and backward particle-tracking maps indicated that the most prevalent areas of recharge in the discretized hydrogeologic framework used in this study were within about
0.6-0.9 mile of the thermal springs. Forward particle tracking indicated a recharge area southwest of the thermal springs that corresponded to a location where the predominant lithologies are the Arkansas Novaculite, Hot Springs Sandstone, and Bigfork Chert. Backward particle tracking indicated a second localized area of recharge to the northeast of the thermal springs that corresponded to a location where the dominant lithology is the Bigfork Chert. The groundwater-flow model indicated that the most probable recharge formations are the Arkansas Novaculite, Bigfork Chert, and Hot Springs Sandstone.

The simulated effects of climate and land-use changes on the variability of the spring-flow rates at the thermal springs generally resulted in reductions of thermal spring flow attributed to urban development and more extreme climates characterized by elevated mean surface air temperatures. The groundwater-flow model predicted a linear relation between the thermal spring discharge and the cumulative recharge volume applied to the hydrogeologic framework, and the positive slope of the predicted relation between recharge and simulated thermal spring flow indicates that more extreme precipitation events that supply more recharge may in fact increase the thermal spring-flow rates.

\section{Introduction}

Hot Springs Reservation was established by the U.S. Congress in 1832 and was designated as Hot Springs National Park in 1921 to protect the artesian thermal springs that discharge from the southwestern slope of Hot Springs Mountain (Petersen and Mott, 2002). Hot Springs National Park, located in Hot Springs, Arkansas, features 47 artesian thermal springs that have been designated as significant geothermal features by the Geothermal Steam Act Amendments of 1988 (Petersen and Mott, 2002), in addition to several cold-water springs and a National Historic Landmark known as "Bathhouse Row" that provides facilities for recreational use of the thermal springwater. The springwater is channeled through a single gage into 
a collection system (Yeatts, 2006), and most is conveyed to the bathhouses that line Bathhouse Row, in addition to a few select hotels. A smaller portion of the springwater is diverted to three separate public-use fountains. The thermal springs are therefore a source of public recreation and are the primary features upon which the park, the unique cultural setting, and the local tourism-based economy of the city of Hot Springs, Arkansas, depend.

The thermal springs are also a source of scientific intrigue. Scientific interests in the thermal springs were first documented in 1804 when the first documented measurement of the springwater temperature, measured at 67.8 degrees Celsius $\left({ }^{\circ} \mathrm{C}\right.$; Weed, 1902), was reported. Since 1804 , geologists and geochemists have shown through their research that the springs emerge from the plunging crest line of the large overturned Hot Springs anticlinorium (Bedinger and others, 1979), and they are sustained entirely by local recharge areas whose locations are currently (2021) based on indirect evidence and thought to lie within about 10 miles of the thermal springs. Geochemical data have further indicated that the groundwater that recharges the thermal springs is differentiated into two separate flow constituents that each travel separate flow paths through the subsurface from the recharge location to the thermal springs. Groundwater is differentiated into a shallow, "cold-water" constituent (hereinafter referred to as the "cold-water" or "cold" constituent) and a deep, thermal constituent and each constituent is characterized by a remarkably different residence time and flow depth. The residence times of the cold and thermal constituents, as quantified from geochemical data, are less than 20 years and greater than 4,400 years, respectively (Bell and Hays, 2007; Kresse and Hays, 2009). The estimated flow depth of the thermal constituent is 7,500 feet (ft) or more (Bedinger and others, 1979).

Despite substantial advances in scientific understanding of the origins of the thermal springs since 1804, many aspects regarding the long-term variability of the spring-flow rates remain uncertain. Uncertainty is, in part, attributed to the limited understanding of the structurally complex hydrogeologic framework of the groundwater-flow system and its exerted influence upon the flow paths and residence times of the cold and thermal constituents of groundwater flow. Consequently, additional scientific questions remain unanswered. This investigation addresses two outstanding questions pertaining to the natural groundwater-flow system. First, what is the origin of the recharge to the thermal springs? Second, what are the potential effects of climate and land-use changes on the long-term variability of the thermal spring-flow rates? Previous scientific investigations have provided meaningful, yet predominantly inconclusive insight into both aspects of the groundwater-flow system; however, answers to the first question depend upon factors that need to be more definitively constrained and characterized, and answering the second question is a difficult task because of the unknown aspects of groundwater-flow and heat-transport processes occurring within the hydrogeologic framework of Hot Springs National Park. The need for better answers to these questions requires development of a coupled surface-water and groundwater-flow model to serve as an investigative tool to support continued research.

This report addresses these identified gaps in the scientific apperception of the thermal springs at Hot Springs National Park by using coupled surface-water and groundwater-flow models, constructed by the U.S. Geological Survey (USGS) in cooperation with the National Park Service. A surface-water model was constructed in version 4 of the Precipitation-Runoff Modeling System (hereinafter referred to as the "PRMS model") (Markstrom and others, 2015) and used to simulate aerially distributed recharge in Hot Springs National Park and the surrounding region that was dependent upon anticipated climate and land-use change within the vicinity of Hot Springs, Arkansas. A groundwater-flow model was constructed in MODFLOW-2005 (Harbaugh and others, 2000) (hereinafter referred to as the "MODFLOW model") and coupled to the PRMS model by incorporating the PRMSsimulated recharge as a specified-flux boundary condition in the numerical solution of the steady-state groundwater-flow equation (Wang and Anderson, 1982; Anderson and Woessner, 2002). Numerical solutions to the groundwater-flow equation were performed in steady state to simulate spring-flow rates at the thermal springs established by the groundwater-flow system in response to stresses attributed to recharge variability.

\section{Purpose and Scope}

The purpose of this report is to describe the development, calibration, and use of the PRMS and MODFLOW models, with an emphasis on generating a conceptual model of groundwater flow through the deep flow system at Hot Springs National Park more so than developing a true calibration dataset. This report specifically describes (1) the PRMS model used to quantify aerially distributed recharge applied to the MODFLOW model as a boundary condition, (2) the hydrogeologic framework developed and used in the MODFLOW model, (3) the manual calibration of the MODFLOW model to historical daily mean thermal spring flow, (4) particle-tracking simulations to estimate a plausible recharge area in the MODFLOW model framework, and (5) the results of the PRMS and MODFLOW model simulations including predictive forecasting of thermal spring-flow variability attributed to climate and land-use changes.

\section{Previous Investigations}

The thermal springs of Hot Springs National Park have been the focus of several scientific studies completed between the early 19th century and present (2021). Many of these studies have emphasized some specific aspect of the thermal springs and their relation to the interconnected hydrogeologic framework in the subsurface. Collectively, the previous studies have culminated in the currently accepted conceptual model of recharge and groundwater flow to the thermal springs. 
Early researchers such as Purdue (1910) and Bryan $(1922,1924)$ provided descriptions of the local and regional geology, as well as discussions of the postulated origins of the thermal springs and their source(s) of heat. Following in the footsteps of these researchers and others, Albin (1965) outlined the regional tectonic setting and described the geologic processes that formed the present-day geologic structure and aquifers encountered within the Ouachita Province and the effects of those processes on the present-day surface-water and groundwater resources in the region. Building upon these investigations, Bedinger and others (1979) conducted the first in-depth water-quality analyses of the thermal springs and developed the first published "hydrothermal" mathematical models of the flow system to test the debated theories on the recharge formations and locations and the hydraulics of the groundwater-flow system that sustain the thermal spring flows. Bedinger and others (1979) constructed two models. The first model tested the hypothesis that the Bigfork Chert is the primary recharging formation, whereas the second model tested the hypothesis that the Arkansas Novaculite is the primary recharging formation. Bedinger and others (1979) noted critical constraints in both models that limited their conclusions regarding the recharge formation(s) and the source(s) of heat. In their first model, an abnormally high uniform heat flux was required as a boundary condition at the base of the model. Although the required heat flux exceeded the maximum known value of crustal heat flow in the eastern United States (Bedinger and others, 1979), the model was able to adequately simulate the observed temperature of the thermal springs and supplied enough hydraulic head at the theorized recharge location to recharge the thermal springs. This was not the case in their second model, in which the available head was the critical constraint. In their second model, the hydraulic head required to recharge the thermal springs through the Arkansas Novaculite exceeded the available head supplied by the recharge by a factor of three.

More recently, Yeatts (2006) focused on defining the recharge area for the shallow, cold groundwater constituent by continuously monitoring discharge and temperature at eight thermal springs and at the collection system reservoir. In this study, dye tracing with fluorescent dyes was used to develop a conceptual model of the groundwater-flow system and to delineate recharge locations for the thermal and cold groundwater constituents. In a related study, Bell and Hays (2007) sampled water-quality at nine hot-water springs and two cold-water springs and performed continuous temperature monitoring at four of the hot-water springs for a duration of 2 years to better understand the contributions of the cold groundwater constituent to the thermal springs. Their data indicated that the water quality of the thermal springs was influenced to some degree by the cold groundwater constituent. Their conclusions were supported by observations of substantial differences in water quality of the thermal springs during base-flow and stormflow events, in addition to observations of short time-scale temperature reductions at the thermal springs in response to mixing with the locally derived cold groundwater constituent after storm events. However, their water-quality data indicated that little water-quality change has occurred with respect to base-flow conditions at the springs when compared to data from studies dating back to the 1800 s. The continuously monitored temperature data did not support the idea that long-term temperature changes have occurred through time at the thermal springs.

Following Yeatts (2006) and Bell and Hays (2007), Kresse and Hays (2009) studied the coincidence of two distal thermal wells outside of Hot Springs National Park boundaries by a comparative analysis of the geochemical characteristics of cold-water springs and wells, distal thermal wells outside of the park, and the thermal springs in the park. Their study evaluated the degree of hydraulic connectivity between the distal thermal wells and the thermal springs in Hot Springs National Park. They concluded that the two very different isotopic and geochemical signatures observed for the distal thermal wells did not provide evidence of any direct hydraulic connection between the water in the distal wells and the thermal springs in Hot Springs National Park. Furthermore, they concluded that the deep flow systems for thermal waters encountered within the region were likely unique to localized hydrogeologic settings.

\section{Geologic Description of Study Area}

Hot Springs National Park is in central Arkansas and encompasses the city of Hot Springs, Arkansas (fig. 1). The park lies entirely within the Ouachita Physiographic Province (Fenneman and Johnson, 1946). The structural fabric of the Ouachita Province is a direct result of the tectonic events described by Albin (1965), which began in the Paleozoic Era with the formation of a long, narrow geosynclinal trough, followed by the subsequent infilling of the trough by deposition of a great thickness of clastic sediments. Sediment deposition was interrupted by continental collision and the ensuing deformation of the sediment wedge into a complex folded, thrust-faulted arch. Periods of collision and deformation were followed by a long period of uplift and erosion, which has led to the present-day expressions of the geologic formations observed in outcrop and their subsurface stratigraphic relations.

Continental collision induced intricate folding at regional and local scales and led to overturning of complete and partial geologic sequences (Arkansas Geological Survey, 2016). At present (2021), the Hot Springs anticlinorium is intensely folded and overturned to the south and dips to the north at 15-60 degrees. The major folds consist of numerous smaller folds that are tight and compressed, strike northeast, and overlap one another laterally in a discontinuous manner over long distances (Purdue, 1910; Bryan, 1922). Thrust faults occur parallel to the strikes of the fold axes. The thermal springs discharge from the ground near a mapped thrust fault, along a belt that is approximately $1,300 \mathrm{ft}$ long and a few dozen feet wide at the southwestern base of Hot Springs Mountain 


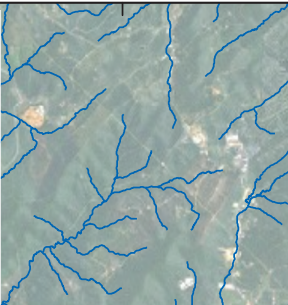

$$
\text { boundary }
$$

PRMS hydrologic response units (HRUs) for the Gulpha Creek watershe

PRMS HRUs for the rest of

rest of the modeling domain

Approximate recharge area

MODFLOW model boundary

$\triangle$ USGS streamgage

$34^{\circ} 35^{\prime}$

on Hot Springs thermal spring

- Hot Springs surficial well
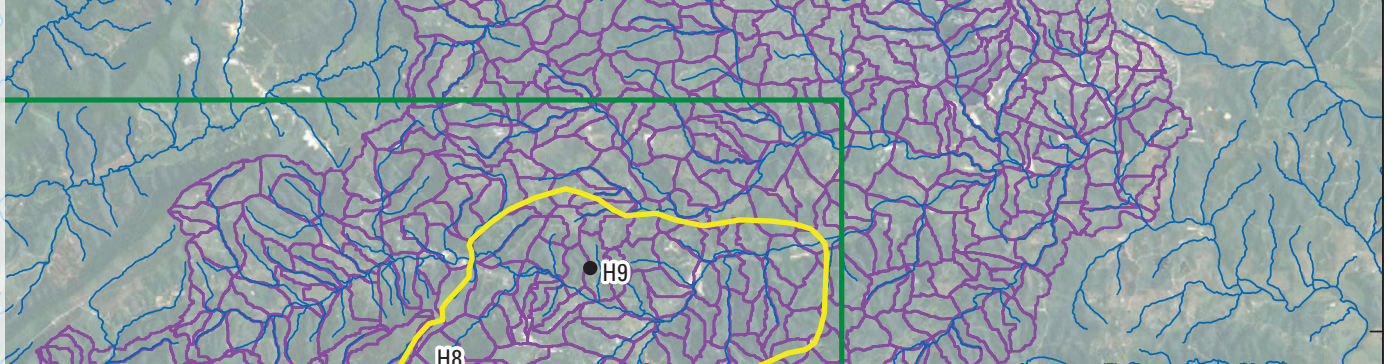

$34^{\circ} 30^{\prime}$

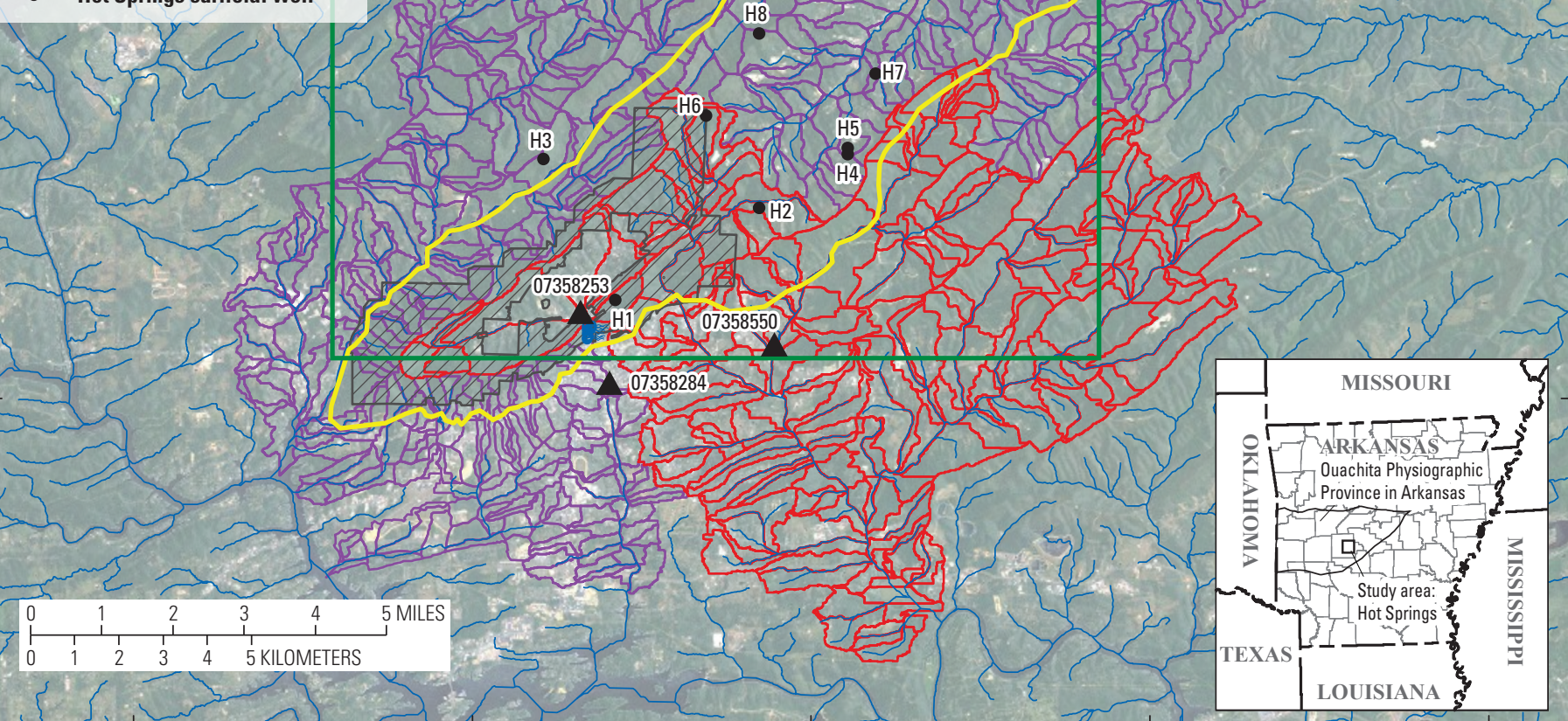

Map image is the intellectual property of Esri and is used herein under license.

Copyright (c) 2013 Esri, i-cubed, GeoEye. All rights reserved.

Figure 1. Locations of the Gulpha Creek streamgage (U.S. Geological Survey [USGS] station 07358550), Hot Springs thermal springs, Hot Springs watershed and surrounding area streams, hydrologic response units delineating the Precipitation-Runoff Modeling System (PRMS) model boundaries, approximate recharge area, well heads H1-H9, MODFLOW groundwater-flow model boundary, the city of Hot Springs, and the Hot Springs National Park boundary, Arkansas. 
(fig. 2, Bryan, 1922; Bedinger and others, 1979). The thermal springs are located on the nose of a southwestern-plunging anticline that is part of the larger anticlinorium. This general structural configuration-wherein thermal springs tend to be found at the noses of plunging anticlines and closely aligned with mapped thrust faults - is observed for all documented occurrences of thermal springs across the Ouachita Province (Kresse and Hays, 2009).

\section{Hydrogeologic Description of Study Area}

The regional surficial geology controlling hydrogeologic processes in Hot Springs National Park is shown in figure 2. The folding, faulting, and extreme dips of the geologic formations plunge the formations to great depths. Groundwater travels vertically downward through these highly fractured formations to estimated depths of 4,500-7,500 ft at an estimated flow velocity of $1-10$ feet per year (ft/yr; Bedinger and others, 1979). The groundwater is heated along the deep flow path by the local geothermal gradient of 0.006-0.01 degrees Celsius per foot $\left({ }^{\circ} \mathrm{C} / \mathrm{ft}\right.$; Bedinger and others, 1979) and attains a maximum estimated temperature of $63-68{ }^{\circ} \mathrm{C}$ along the flow path (Bedinger and others, 1979; Bell and Hays, 2007). The geothermal heat source is generally agreed upon as being the most probable heat source, although past researchers have debated if the origin of the heat is magmatic (Weed, 1902; Purdue, 1910; Bryan, 1922), or a result of the convective upwelling of heated juvenile water (Arndt and Stroud, 1953). Researchers now consider that the thermal effects on the buoyancy and kinematic viscosity of the groundwater at these temperatures and depths, combined with the presence of the permeable conveyance conduits created by joints, fractures, and faults, cause the heated groundwater to travel vertically upwards under artesian pressure. The travel time from depth to the surface is rapid (on the order of a few years) in comparison to the travel time required for the groundwater to reach the maximum flow depth (on the order of several thousand years). This concept is supported by observations of silica concentrations in the thermal groundwater constituent, which indicated that the maximum temperature achieved at depth is only a few degrees greater than the average temperature of the thermal springs. Silica data collected by Bell and Hays (2007) were used with the methods of Fournier and Rowe (1966) to calculate the maximum temperature of the groundwater conveyed along the deep flow path. Bell and Hays (2007) estimated a maximum groundwater temperature of about $66.6^{\circ} \mathrm{C}$ based on the maximum silica concentration from thermal spring baseflow data - an estimate that is $3.4^{\circ} \mathrm{C}$ higher than the source temperature of $63.2^{\circ} \mathrm{C}$ previously reported by Bedinger and others (1979).

Although the spring flows are thought to be sustained exclusively by recharge occurring over the eroded anticlinal complex, some speculation regarding the presence or absence of a component of interbasin flows has occurred. Through base-flow analysis, Bedinger and others (1979) concluded that interbasin transfers of groundwater from several adjacent stream basins likely contribute to the thermal groundwater constituent and therefore the thermal springs. Kresse and Hays (2009), however, found no evidence of interbasin transfers of the cold groundwater constituent. 


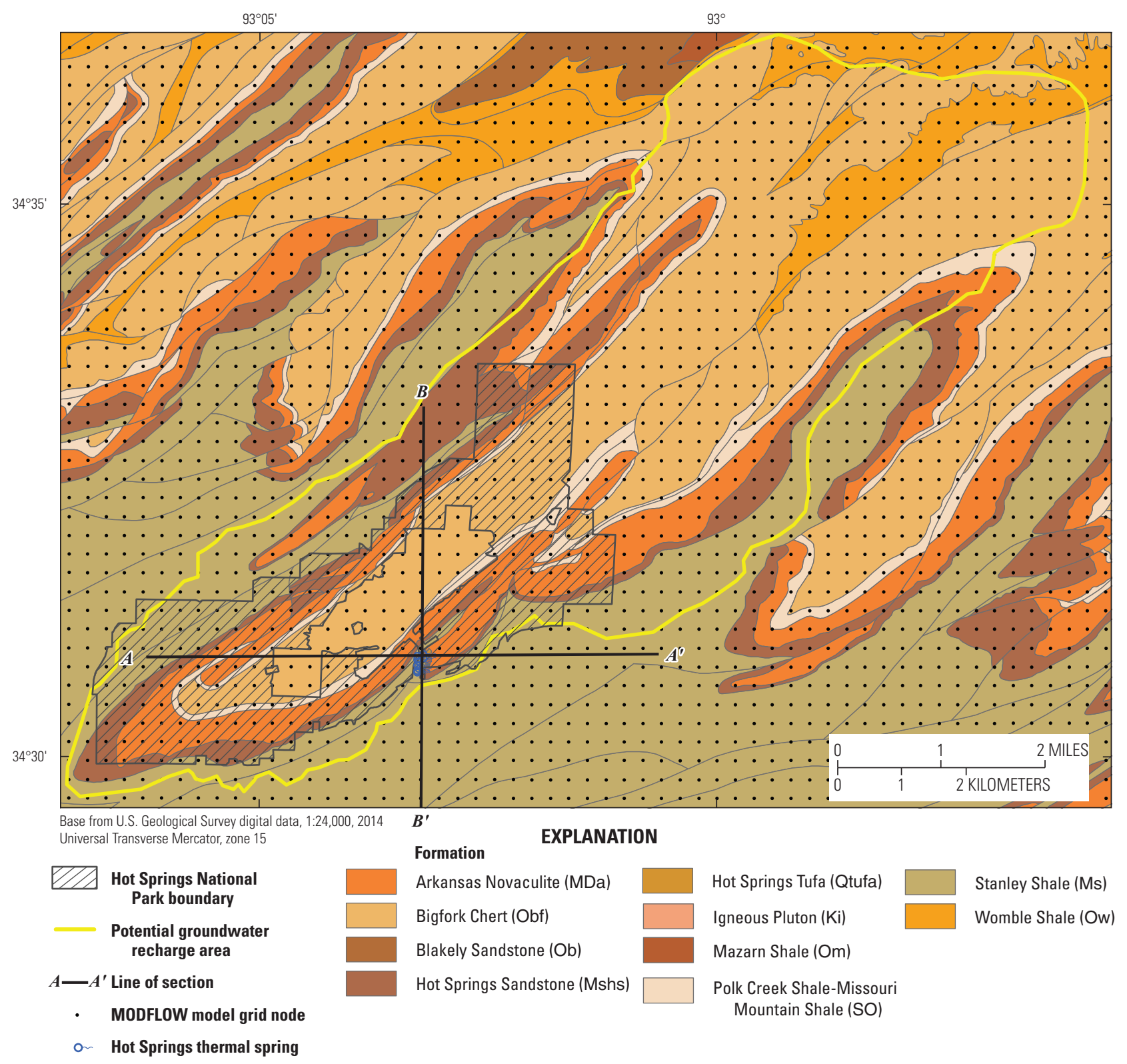

Figure 2. The regional surficial geology controlling hydrogeologic processes in Hot Springs National Park with decimated MODFLOW groundwater-flow model grid. Each grid node is separated from surrounding grid nodes by 984.25 feet corresponding to a model-grid decimation of 10 (the full model grid has 10 times the number of nodes shown in both the $\mathrm{x}$ and $\mathrm{y}$ directions). 


\section{Delineation of the Recharge Area}

The thermal springs in Hot Springs National Park exist because the formations that recharge them exhibit the following general characteristics: (1) the formations are permeable, and their outcrop areas are large enough to accrue enough recharge to yield thermal spring discharge of about 88,000 cubic feet per day $\left(\mathrm{ft}^{3} / \mathrm{d}\right)$, or about 1 cubic foot per second $\left(\mathrm{ft}^{3} / \mathrm{s}\right)$, (2) water-level elevations within the recharging formations provide sufficient hydraulic head for the thermal springs to emerge from the ground at elevations between 576 and $683 \mathrm{ft}$ (Bedinger and others, 1979), and (3) the recharge area is hydraulically connected to the thermal springs and capable of supplying a recharge of at least 2-6 inches per year (in/yr; Bedinger and others, 1979). Based on these characteristics, three formations are considered plausible for supplying the majority of recharge to the thermal springs. Recharge to the thermal springs is theorized to occur primarily through the secondary porosity of the Bigfork Chert and the Arkansas Novaculite Formations (fig. 2), and to a lesser degree, through the less extensive outcrop of the Hot Springs Sandstone Member - a member of the Stanley Shale (hereinafter referred to as the Hot Springs Sandstone following usage from the Arkansas Geological Survey [Johnson and Hanson, 2011; McFarland, 2004]). These formations are characterized by relatively high permeability because of abundant faulting and fracturing, and water levels in some areas of their outcrops exceed $850 \mathrm{ft}$ elevation (Nottmeier and Hays, 2019). The formations are part of the eroded, thrust-faulted anticline from which the thermal springs emerge at the nose, and therefore represent the most structurally, topographically, and stratigraphically suitable area meeting the recharge criteria listed above.

The hydraulic head in the recharge area that is required to recharge the thermal springs is affected by groundwater temperature, total dissolved solids (TDS), the flow path length, and frictional head losses that occur along the flow path between the recharge area and the thermal springs (Zhang and Nemcik, 2013). Temperature increases that occur along the flow path reduce the groundwater density and the hydraulic head that is required in the recharge area. In contrast, an increase of TDS along the flow path increases the groundwater density and the hydraulic head that is required in the recharge area. For example, groundwater with 200 milligrams per liter $(\mathrm{mg} / \mathrm{L}) \mathrm{TDS}$ and a temperature of $66.6^{\circ} \mathrm{C}$ at the thermal springs (the approximate temperature of the hot-water column) is about 98.9 percent as dense as the groundwater contained within the upstream segments of the flow path where lower TDS of about $110 \mathrm{mg} / \mathrm{L}$ and reduced temperature of about $42{ }^{\circ} \mathrm{C}$ are common (these values are representative of the conceptual model of the thermal springs considered by Bedinger and others [1979]). A 5,000-ft column of groundwater at an average temperature of about $42{ }^{\circ} \mathrm{C}$ is therefore roughly equivalent to a $5,055-\mathrm{ft}$ column of groundwater at a temperature of $66.6^{\circ} \mathrm{C}$. The implication is that the recharge area could be lower in elevation than the discharge elevation of the thermal springs (Bedinger and others, 1979).

Consideration of the previously listed characteristics enabled an estimate of the recharge area and its elevation, which are depicted in figure 3. Simple Darcy calculations that incorporated hydraulic conductivity constraints based on available local data indicated that hydraulic head in the recharge area must be sufficiently high relative to the elevation of the thermal springs in order to produce the discharge rates measured at the thermal springs. Based on the elevation of the thermal springs, and in consideration of water-density effects attributed to groundwater temperature increases along the flow path, the outcrop areas of the Bigfork Chert, Arkansas Novaculite, and Hot Springs Sandstone that lie above an elevation of $660 \mathrm{ft}$ on the Hot Springs anticlinorium were considered the most likely recharge areas because they exhibit the aforementioned criteria in the delineated recharge area (fig. 3). Throughout the delineated recharge area (fig. 3), the rocks of these formations are permeable enough to convey water into the deep subsurface, and the hydraulic head is sufficient to convey groundwater flow through the subsurface to the thermal springs. Geologic maps of the anticlinorium (Johnson and Hanson, 2011) show that about 8 square miles $\left(\mathrm{mi}^{2}\right)$ of Bigfork Chert, about $5 \mathrm{mi}^{2}$ of Arkansas Novaculite, and about $3 \mathrm{mi}^{2}$ of Hot Springs Sandstone outcrop at elevations above $660 \mathrm{ft}$. The recharge area delineated in figure 3 therefore totals approximately $16 \mathrm{mi}^{2}$; however, this estimate is conservative because the shales and siltstones of the Stanley Shale, Polk CreekMissouri Mountain Shale, and Womble Shale formations are not considered. The shales of these formations do outcrop at elevations that are high enough to provide recharge to the thermal springs, and these formations are highly fractured and capable of transmitting groundwater at shallow depths where overburden pressure has not effectively closed the fractures. Furthermore, thousands of shallow domestic wells produce water from these formations, and the shallow groundwater levels within these formations show notable and rapid responses to recharge events. However, these wells rarely produce water at depths below about $180 \mathrm{ft}$ (Kresse and Hays, 2009), indicating that the overburden stress is great enough to close fractures in the deeper regions of these more labile formations and prevent groundwater flow to the depths necessary to recharge the thermal springs. The Arkansas Novaculite, Bigfork Chert, and Hot Springs Sandstone are therefore regarded herein as the formations that serve as the principal recharge source of the thermal springs, and the estimated recharge area is delineated in figure 3. 


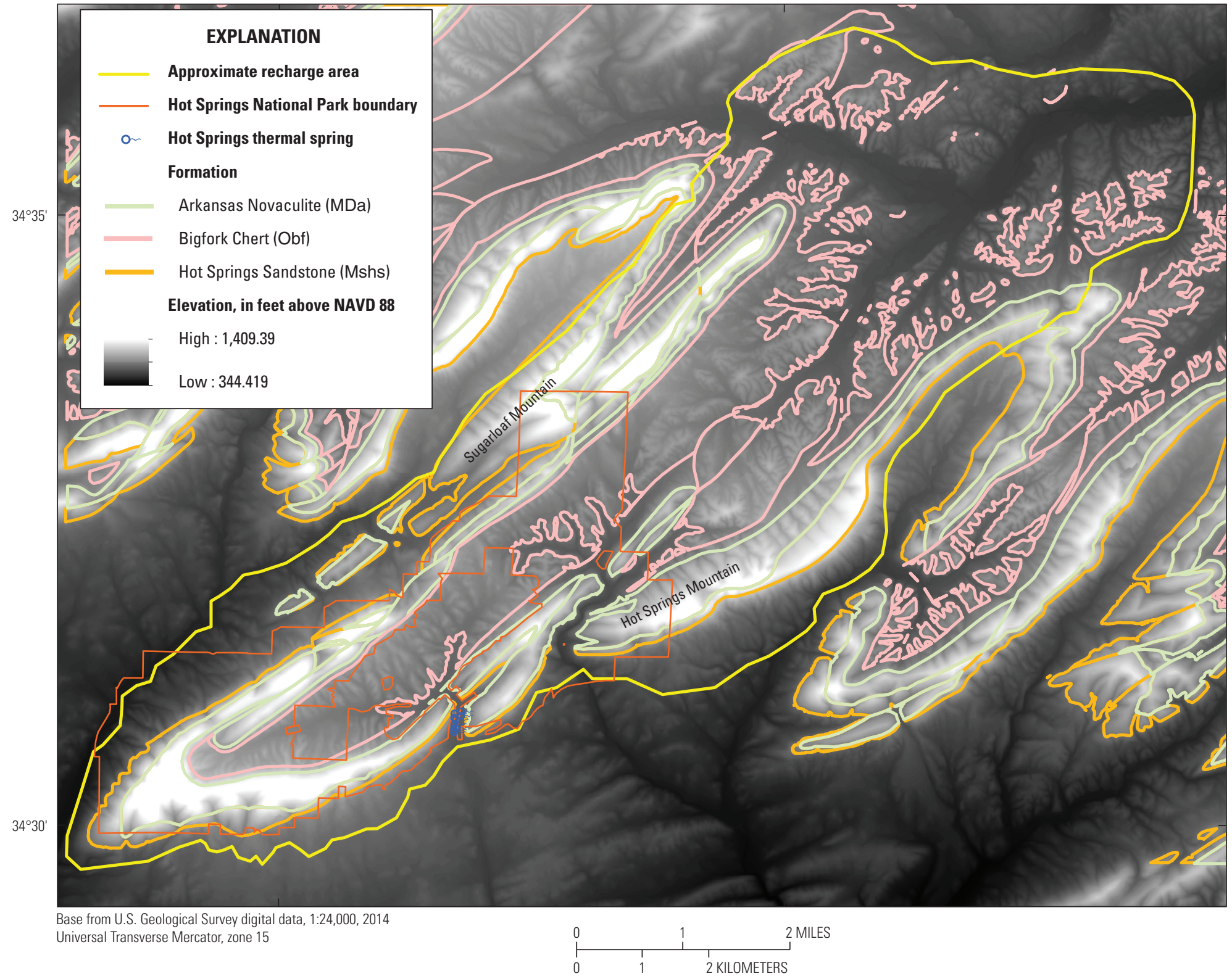

Figure 3. Locations of formations contributing to the estimated recharge area for the Hot Springs thermal springs and elevations of the recharge area near Hot Springs National Park, Arkansas. [NAVD 88, North American Vertical Datum of 1988] 


\section{PRMS Model Development}

The following sections of this report describe the development of the PRMS model used to simulate the hydrologic cycle and quantify recharge at the watershed scale. PRMS is a modular, deterministic, distributed-parameter model that has been used in many hydrologic applications to evaluate the effects of climate and land use on general watershed hydrology (Markstrom and others, 2015). All input and output files for the PRMS watershed model described herein are provided in a related data release (Hart and Ikard, 2021).

The PRMS model domain included all of the hydrologically similar units shown in figure 1 , referred to as hydrologic response units (HRUs), and overlapped the MODFLOW groundwater-flow model domain. Stream segments are the smallest geographic features that can be simulated by the PRMS model, and they are simulated in the PRMS model as channelized flow (Markstrom and others, 2015).

The PRMS model maintains a daily water balance of the entire watershed and simulates all processes of the hydrologic cycle by using daily time-series of precipitation, incident solar radiation, and maximum and minimum air temperatures as inputs. Precipitation in the form of rain, snow, or a mixture of rain and snow is either intercepted by the vegetative canopy or converted to throughfall onto the watershed surface. At the watershed surface, precipitation that either runs off into stream segments, lakes, or adjacent HRUs or infiltrates into the soil is subjected to evapotranspiration controlled by daily temperature and incident solar radiation. The impervious portions of the watershed surface have no infiltration capacity, and maximum storage capacity in the soil must be met before surface runoff can occur (Markstrom and others, 2015).

Three conceptual soil reservoirs are represented within the PRMS model, and groundwater flow is simulated between each of these soil reservoirs based on antecedent conditions in adjacent soil reservoirs and the soil properties distributed within them (Markstrom and others, 2015). The reservoirs, from top to bottom) are (1) the preferential-flow reservoir, which enables simulation of fast lateral interflow, (2) the capillary reservoir, which accounts for volumetric soil moisture between the wilting point and field-capacity extremes, and (3) the gravity reservoir, which enables simulation of slow, lateral interflow and gravity drainage out of the soil column. Gravity drainage accounts for base flow to the stream network and serves as a groundwater sink to represent drainage out of the soil column (Markstrom and others, 2015). Gravity drainage simulated by the PRMS model was incorporated into the MODFLOW model as recharge.

\section{PRMS Model Climate Inputs}

Historical and future climate data were input into the PRMS model to simulate the water cycle at the watershed scale. Historical data included daily precipitation, minimum and maximum surface air temperatures, and incident solar radiation from 1980 to 2014, each produced by the University of Idaho's Gridded Surface Meteorological Dataset (gridMET Climatology Lab) (Abatzoglou, 2013). The historical climate data were downloaded from the USGS Geo Data Portal (Blodgett and others, 2011, 2012) and were used to derive a spatially and temporally continuous high-resolution gridded climate dataset, which ultimately was used to produce a baseline recharge condition for use as a boundary condition during calibration of the MODFLOW model.

The future climate data consisted of predicted daily precipitation and minimum and maximum surface air temperatures for the conterminous United States for the period 2015-2099. These data were produced by several global climate models (GCMs) of the Phase 5 Coupled Model Intercomparison Project (CMIP5) (World Climate Research Programme, 2020). Future climate data were used as inputs to the PRMS model to simulate potential future climate conditions and the corresponding recharge fluxes that were used as boundary conditions in predictive simulations using the MODFLOW model. The future climate data were downscaled by the Multivariate Adaptive Constructed Analogs method (Abatzoglou and Brown, 2012) by using the gridMET data (Abatzoglou, 2013) as a training dataset. The downscaling was based on the 365-day outputs from different GCMs that used historical (1950-2005) and future (2006-2099) Representative Concentration Pathway (RCP) scenarios of 4.5 and 8.5, respectively (Pachauri and Meyer, 2014). GCMs corresponding to the two RCPs were selected to examine moderate and extreme greenhouse gas emission scenarios for the Hot Springs National Park area, which are characterized by RCPs of 4.5 and 8.5 , respectively. The global mean surface air temperature was projected to rise for the period 2016-2035 under both of the greenhouse emissions scenarios considered. After 2035, the global mean surface air temperature changes through 2099 were dependent upon the specific greenhouse gas emissions scenario. An RCP of 4.5 resulted in a moderate surface air temperature change corresponding to a global mean surface air temperature increase of $1.8^{\circ} \mathrm{C}$, whereas an RCP of 8.5 resulted in the most extreme surface air temperature change corresponding to a global mean surface air temperature increase of $3.7^{\circ} \mathrm{C}$ (Pachauri and Meyer, 2014). In all cases, an increase in mean surface air temperature was predicted for the Hot Springs National Park area by the end of the century. Precipitation predictions were more uncertain than temperature predictions for this region; however, the general consensus is that intense rainfall events will likely increase in frequency in the future (Carter and others, 2014).

\section{PRMS Model Parameters}

Numerous datasets were required to define the static parameters of the PRMS model. The required datasets were part of the Geospatial Fabric (Viger, 2014; Viger and Bock, 2014) and included (1) the National Elevation Dataset (USGS, 
2019a) for delineating HRUs in the PRMS model domain (fig. 1), (2) the National Hydrography Dataset (USGS, 2019b) for delineating the stream reaches within the Gulpha Creek watershed (fig. 1), (3) the 2001 National Land Cover Database (Homer and others, 2007) to quantify the static PRMS parameters related to land cover, and (4) the Soil Survey Geographic database (SSURGO; U.S. Department of Agriculture, 2019a, b) to quantify the PRMS parameters related to the soils in the Gulpha Creek watershed. Other important parameters that control the recharge processes in the PRMS model are listed in table 1.

\section{Calibration of the PRMS Model}

The PRMS model was calibrated to historical daily mean streamflow data measured at the Gulpha Creek streamgage (USGS station 07358550, Gulpha Creek at Hot Springs, Arkansas [figs. 1 and 4]) between August 14, 2009, and December 31, 2014 (USGS, 2019c). The PRMS model was calibrated in a two-step sequence to produce a long-term mean recharge for use in calibrating the MODFLOW model. First, a baseline PRMS simulation was performed by using historical climate data representing the period January 1, 1980, to August 14, 2009, to allow the simulated water balance to converge on a stable antecedent soil moisture condition. The antecedent soil moisture condition was then used in the second step, and the PRMS model was calibrated to historical daily mean streamflow from August 14, 2009, to December 31, 2014, by using historical climate data.

The time-series of PRMS-simulated daily mean streamflow compared reasonably well with the daily mean streamflow data measured at the Gulpha Creek streamgage (fig. 4). The mean absolute error and the root mean square error (RMSE) between the calibrated and measured daily mean streamflow were $3.63 \mathrm{ft}^{3} / \mathrm{s}$ and $7.58 \mathrm{ft}^{3} / \mathrm{s}$, respectively (table 2). The means of the simulated and measured streamflow data compared well also; the mean of the simulated streamflow data was $6.20 \mathrm{ft}^{3} / \mathrm{s}$, and the mean of the measured streamflow data at the Gulpha Creek gage was $7.20 \mathrm{ft}^{3} / \mathrm{s}$, corresponding to an error of about 14 percent (table 2). Based on the modelfit statistics (table 2), the corresponding performance ratings given by Moriasi and others (2007) indicate that the calibration of the PRMS model falls within the category of "acceptable" to "very good."

\section{PRMS Model Results}

The PRMS model results are shown graphically in figure 5 and in map view in figure 6 . The annual mean precipitation supplied to the PRMS model (fig. 5) was approximately $47 \mathrm{in} / \mathrm{yr}$ for the calibration period 1980-2014. The minimum of $34.0 \mathrm{in} / \mathrm{yr}$ occurred in 2005, and the maximum of $69.6 \mathrm{in} /$ yr occurred in 2009. Using the annual mean precipitation time series as a PRMS model input, the PRMS-simulated annual mean surface runoff (fig. 5) was about $4.1 \mathrm{in} / \mathrm{yr}$ and varied between the minimum of $2.4 \mathrm{in} / \mathrm{yr}$ in 1981 and 2005 and the maximum of $8.1 \mathrm{in} / \mathrm{yr}$ in 2009. The PRMS-simulated annual mean recharge over the entire PRMS-model domain was approximately $7.9 \mathrm{in} / \mathrm{yr}$ and varied between the minimum of $1.4 \mathrm{in} / \mathrm{yr}$ in 1981 and the maximum of $18.7 \mathrm{in} / \mathrm{yr}$ in 2009. The annual mean recharge simulated by PRMS within any individual HRU (fig. 6) varied between the minimum of $3.3 \mathrm{in} / \mathrm{yr}$ and the maximum of $12.1 \mathrm{in} / \mathrm{yr}$ depending on the soil and land cover properties.

The PRMS-simulated annual mean recharge (7.9 in/yr) compared reasonably well to the independent recharge estimate of 2-6 in/yr published by Bedinger and others (1979). To further evaluate the validity of the PRMS-simulated recharge, the PRMS-simulated values were compared to estimates simulated by three additional models. The first of these models was the Hydrologic Evaluation of Landfill Performance v. 3 (HELP3) model (https://www.epa.gov/land-research/ hydrologic-evaluation-landfill-performance-help-model; U.S. Environmental Protection Agency, 2017), which uses a combination of climate, soil, and land-use data to estimate recharge (Jyrkama and others, 2002; Lacombe and others, 2017). The HELP3 model simulation (fig. 7) returned recharge estimates that varied between a minimum of about $0 \mathrm{in} / \mathrm{yr}$ to a maximum of $29.2 \mathrm{in} / \mathrm{yr}$; the annual mean recharge estimated with the HELP3 model was $6.5 \mathrm{in} / \mathrm{yr}$ which compared favorably to the annual mean recharge returned by the PRMS simulation. The second model used the Rorabaugh (RORA) code (Rutledge, 1998, 2000), which is based on recession curve displacement and estimates recharge to the water table based on daily streamflow in a watershed. This model incorporated all streamgages near the Hot Springs National Park study area (table 3) and produced recharge estimates that varied between a minimum of $9.0 \mathrm{in} / \mathrm{yr}$ and a maximum of $24.5 \mathrm{in} /$ $\mathrm{yr}$; the annual mean recharge estimated from the RORA model was $14.9 \mathrm{in} / \mathrm{yr}$ (table 3 ). This estimate was notably larger than the PRMS-simulation but still compared reasonably well. The third model was the Soil-Water-Balance (SWB) model (Westenbroek and others, 2010). The SWB model calculates spatial and temporal variations in groundwater recharge by using a modified Thornthwaite-Mather soil-water balance (Thornthwaite and Mather, 1955, 1957), which is based on daily values of precipitation and temperature, in addition to land-use classification, hydrologic soil groupings, and soilwater retention properties. The SWB model produced recharge that varied between a minimum of $0 \mathrm{in} / \mathrm{yr}$ and a maximum of $74.9 \mathrm{in} / \mathrm{yr}$ (fig. 8); the annual mean recharge estimated with the SWB model was $10.8 \mathrm{in} / \mathrm{yr}$, which was also slightly greater than the PRMS simulation but comparable. The PRMSsimulated annual mean recharge ( $7.9 \mathrm{in} / \mathrm{yr})$ was encapsulated by the mean values obtained from the HELP3, RORA, and SWB models (6.5-14.9 in/yr) and was therefore considered an adequate representation of the actual recharge in the Hot Springs National Park study area and suitable for use as a boundary condition in the MODFLOW model. 
Table 1. Summary of calibrated values for selected hydrology parameters for the Precipitation-Runoff Modeling System (PRMS).

[HRU, hydrologic response unit; ET, evapotranspiration]

\begin{tabular}{|c|c|c|c|}
\hline Parameter name & Description & Units & $\begin{array}{l}\text { Parameter } \\
\text { range or } \\
\text { value }\end{array}$ \\
\hline rain_cbh_adj & $\begin{array}{l}\text { Monthly factor to adjust measured precipitation on each HRU to account } \\
\text { for differences in elevation }\end{array}$ & decimal fraction & $0.60-1.38$ \\
\hline sat_threshold & $\begin{array}{l}\text { Water-holding capacity of the gravity and preferential flow reservoirs; dif- } \\
\text { ference between field capacity and total soil saturation for each HRU }\end{array}$ & inches & 40 \\
\hline slowcoef_lin & $\begin{array}{l}\text { Linear coefficient in equation to route gravity-reservoir storage downslope } \\
\text { for each HRU }\end{array}$ & fraction/day & 0.059 \\
\hline slowcoef_sq & $\begin{array}{l}\text { Nonlinear coefficient to route gravity reservoir storage downslope for each } \\
\text { HRU }\end{array}$ & none & 0.177 \\
\hline soil_moist_max & $\begin{array}{l}\text { Maximum available water-holding capacity of capillary reservoir from } \\
\text { land surface to rooting depth of the major vegetation type of each HRU; } \\
\text { affects Hortonian surface runoff, ET, direct recharge, and flow to gravity } \\
\text { reservoir }\end{array}$ & inches & $5.02-8.35$ \\
\hline soil_rechr_max & $\begin{array}{l}\text { Maximum storage for soil recharge (upper portion of capillary reservoir } \\
\text { where losses occur as evaporation and transpiration); must be less than } \\
\text { or equal to soil_moist_max; affects Hortonian surface runoff and ET }\end{array}$ & inches & $0.21-2.82$ \\
\hline soil2gw_max & $\begin{array}{l}\text { Maximum amount of the capillary reservoir excess that is routed directly to } \\
\text { the groundwater reservoir for each HRU }\end{array}$ & inches & 0.121 \\
\hline ssr2gw_exp & $\begin{array}{l}\text { Nonlinear coefficient used in the equation used to route water from the } \\
\text { gravity reservoirs to the groundwater reservoir for each HRU }\end{array}$ & none & $5.1 \times 10^{-4}$ \\
\hline ssr2gw_rate & $\begin{array}{l}\text { Linear coefficient used in the equation used to route water from the gravity } \\
\text { reservoir to the groundwater reservoir for each HRU }\end{array}$ & fraction/day & 0.753 \\
\hline gwflow_coef & $\begin{array}{l}\text { Linear coefficient in the equation used to compute groundwater discharge } \\
\text { from each groundwater reservoir }\end{array}$ & fraction/day & $0.099-0.145$ \\
\hline gwsink_coef & $\begin{array}{l}\text { Linear coefficient in the equation to compute outflow to the groundwater } \\
\text { sink for each groundwater reservoir }\end{array}$ & fraction/day & 0 \\
\hline gwstor_min & $\begin{array}{l}\text { Minimum storage in each groundwater reservoir to ensure storage is greater } \\
\text { than a specified value to account for inflow from deep aquifers or injec- } \\
\text { tion wells with the water source outside the basin }\end{array}$ & inches & 0.077 \\
\hline cov_type & $\begin{array}{l}\text { Integer specifying vegetation cover type for each HRU }(0=\text { bare soil; } \\
\quad 1=\text { grasses; } 2=\text { shrubs; } 3=\text { trees; } 4=\text { coniferous })\end{array}$ & none & $0-4$ \\
\hline covden_sum & $\begin{array}{l}\text { Summer vegetation cover density for the major vegetation type in each } \\
\text { HRU }\end{array}$ & decimal fraction & $0.000-0.887$ \\
\hline covden_win & Winter vegetation cover density for the major vegetation type in each HRU & decimal fraction & $0.000-0.800$ \\
\hline srain_intcp & $\begin{array}{l}\text { Summer rain interception storage capacity for the major vegetation type in } \\
\text { each HRU }\end{array}$ & inches & $0.00-0.05$ \\
\hline wrain_intep & $\begin{array}{l}\text { Winter rain interception storage capacity for the major vegetation type in } \\
\text { each HRU }\end{array}$ & inches & $0.000-0.046$ \\
\hline carea_max & $\begin{array}{l}\text { Maximum possible area contributing to surface runoff expressed as a por- } \\
\text { tion of the HRU area }\end{array}$ & decimal fraction & 0.6 \\
\hline $\begin{array}{l}\text { hru_percent_im- } \\
\text { perv }\end{array}$ & Fraction of each HRU area that is impervious & decimal fraction & $0.000-0.708$ \\
\hline imperv_stor_max & Maximum impervious area retention storage for each HRU & inches & 0.05 \\
\hline smidx_coef & Coefficient in nonlinear contributing area algorithm for each HRU & decimal fraction & 0.001 \\
\hline smidx_exp & Exponent in nonlinear contributing area algorithm for each HRU & $1 /$ inch & 0.29 \\
\hline
\end{tabular}


Table 2. Summary of model-fit statistics for calibration of the Precipitation-Runoff Modeling System (PRMS) model.

[The PRMS model was calibrated to historical daily mean streamflow at U.S. Geological Survey streamgage 07358550, Gulpha Creek at Hot Springs, Arkansas (U.S. Geological Survey, 2019c) for the period August 14, 1980, to December 31, 2014. RMSE, root mean square error]

\begin{tabular}{lc}
\hline \multicolumn{1}{c}{ Model-fit statistics and unit of measure } & Value \\
\hline Mean absolute error (cubic feet per second) & 3.63 \\
Root mean squared error (cubic feet per second) & 7.58 \\
Mean of simulated streamflow (cubic feet per second) & 6.20 \\
Mean of measured streamflow (cubic feet per second) & 7.20 \\
Pearson's correlation coefficient (unitless) & 0.88 \\
Coefficient of determination (unitless) & 0.78 \\
Nash-Sutcliffe model efficiency coefficient (unitless) & 0.76 \\
RMSE to standard deviation ratio (unitless) & 0.49 \\
Percent bias (PBIAS) (percent) & -13.3 \\
\hline
\end{tabular}

\section{Coupling of the PRMS and MODFLOW Models}

The PRMS model was coupled to the MODFLOW model through the PRMS-simulated recharge, which provided an aerially distributed specified flux boundary condition for the MODFLOW groundwater-flow model. This coupling between the PRMS and MODFLOW models allows for integrated resource management. Changes in recharge rates attributed to future scenarios of climate and land use can be forecasted in the PRMS model and represented in the MODFLOW groundwater-flow model as boundary conditions to simulate the potential effects on the discharge at the thermal springs. 


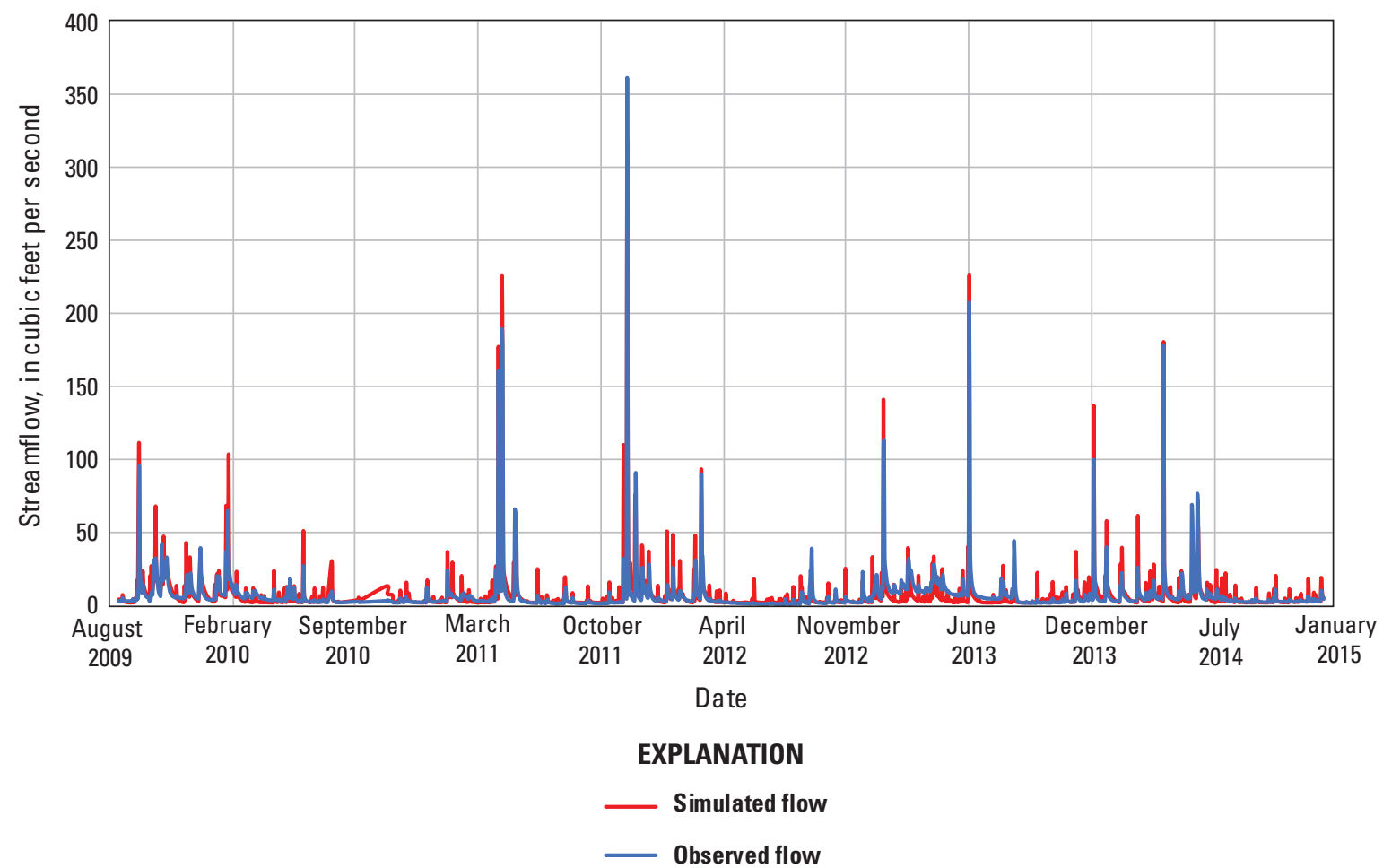

Figure 4. Simulated and measured daily mean streamflow at U.S. Geological Survey streamgage 07358550, Gulpha Creek at Hot Springs, Arkansas, August 14, 2009-December 31, 2014.

\section{MODFLOW Groundwater-Flow Model Development}

The groundwater-flow model of the Hot Springs anticlinorium was developed in MODFLOW-2005 (McDonald and Harbaugh, 1988; Harbaugh, 2005) to evaluate the effects of predicted future climate and land-use changes on thermal spring flow. MODFLOW-2005 simulates groundwater flow in three dimensions (3D) by using the finite-difference method (Wang and Anderson, 1982; Anderson and Woessner, 2002). The following sections describe development of the MODFLOW model framework, spatial and temporal discretization, boundary conditions, parameter values, calibration, sensitivity analysis, and particle-tracking results using MODPATH version 6 (Pollock, 2012), in addition to predictive simulation results. All MODFLOW-2005 and MODPATH version 6 input and output files are available in the related data release (Hart and Ikard, 2021).

\section{MODFLOW Model Discretization and Framework}

The MODFLOW model domain (fig. 1) was bounded by coordinates $\left(93.1179986^{\circ} \mathrm{W} ., 34.610003^{\circ} \mathrm{N}\right.$.), $\left(92.9289994^{\circ}\right.$ W., $34.6099944^{\circ}$ N.), (92.9290047 W., $34.4940003^{\circ}$ N.), and $\left(93.1180072^{\circ} \mathrm{W} ., 34.4939906^{\circ} \mathrm{N}\right.$.), representing the northwest, northeast, southeast, and southwest corner coordinates, respectively. The area encapsulated within these coordinates was spatially discretized into a finite-difference grid (hereinafter referred to as the "model grid") with square cells having equal width of $98.4 \mathrm{ft}$. This discretization resulted in 576 columns and 429 rows in the horizontal dimensions of the model grid and encapsulated a surface area of about $86 \mathrm{mi}^{2}$. The subsurface beneath this area was vertically discretized into 19 confined layers, and the vertical thickness of each model-grid cell varied because of surface topography and the complex subsurface structure of the hydrogeologic units (fig. 9). The model was temporally discretized into one steady-state stress period of 34 years in duration (1980-2014) to represent the calibration period of the PRMS model.

The hydrogeologic framework was represented by six rock formations and one vertical fault placed in every grid layer at the coordinate of the thermal springs. The subsurface expressions of each rock formation are shown in figure 9 in relation to the surficial geology within the subarea of the full model grid delineated by cross sections $A-A^{\prime}$ and $B-B^{\prime}$ (fig. 2). Lithological descriptions of each rock formation are provided by Purdue (1910), Bryan (1922, 1924), Bedinger and others (1979), and Yeatts (2006). The rock formations included in the framework are (from oldest to youngest): (1) the Ordovician Womble Shale, (2) the Ordovician Bigfork Chert, (3) the Ordovician to Silurian Polk Creek-Missouri Mountain Shale, (4) the Mississippian to Devonian Arkansas Novaculite, (5) the Mississippian Hot Springs Sandstone, and 


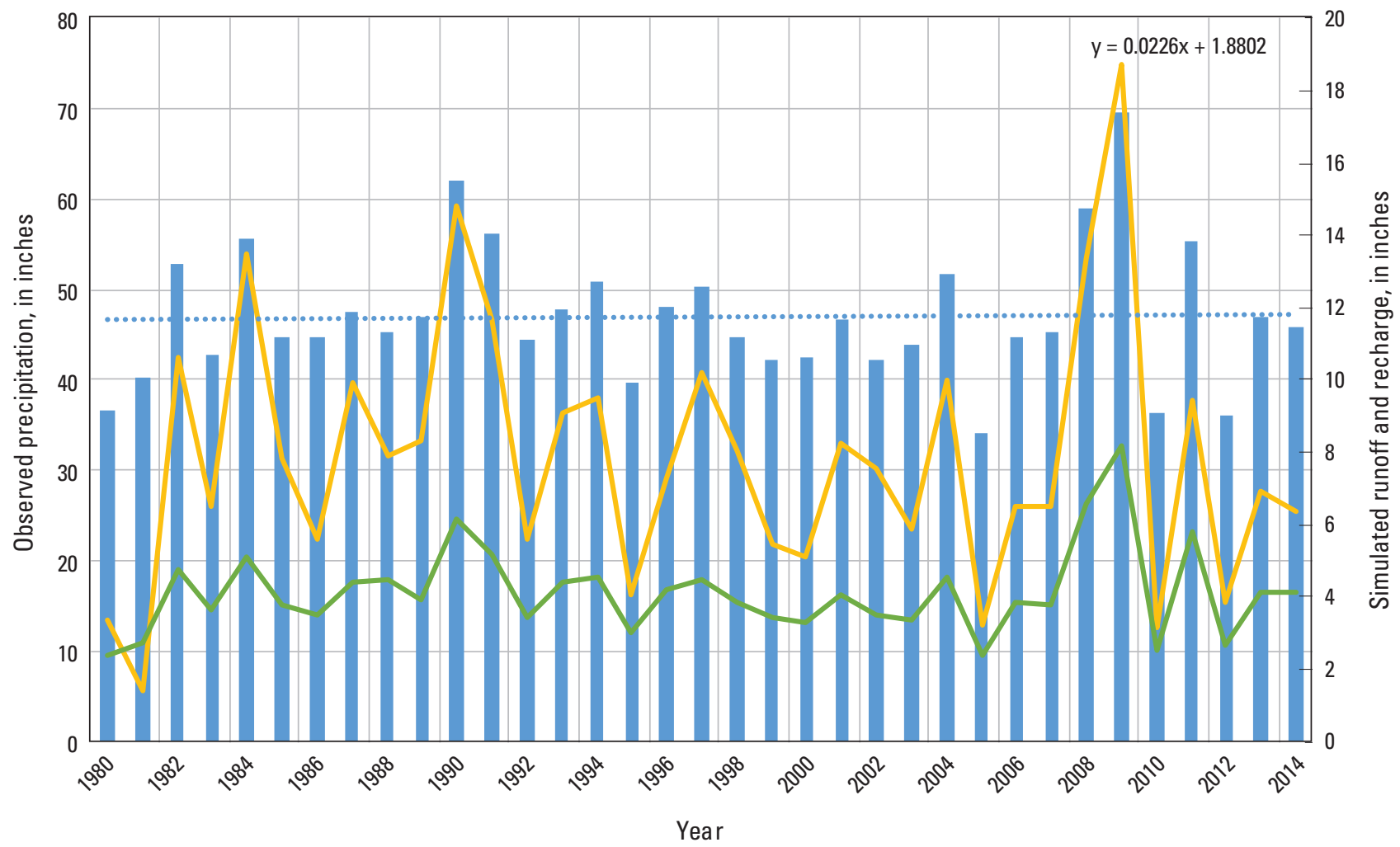

EXPLANATION

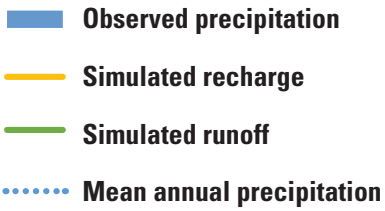

Figure 5. Annual mean precipitation time series used as Precipitation-Runoff Modeling System (PRMS) model input, and PRMS-simulated annual mean runoff and recharge for the simulation period 1980-2014 for the Hot Springs National Park and surrounding area, Arkansas.

(6) the Mississippian Stanley Shale. The Womble Shale is the oldest geologic formation in the framework and underlies all other units (Yeatts, 2006). It is overlain by the Bigfork Chert, which underlies most of the anticlinorium. The Bigfork Chert is highly permeable because of fracturing and is considered one of the likely recharge formations for the thermal springs (Bedinger and others, 1979). The Bigfork Chert is confined by the Polk Creek-Missouri Mountain Shale, which underlies the Arkansas Novaculite. The Arkansas Novaculite is also a potential recharge formation for the thermal springs (Bedinger and others, 1979). It is less permeable than the Bigfork Chert but is fractured and intensely jointed and contains intergranular permeability that could convey groundwater from the theorized recharge locations to the surface at the thermal springs (Bedinger and others, 1979). The Arkansas Novaculite is overlain by the Hot Springs Sandstone, which is the formation from which the thermal springs discharge. The Hot Springs
Sandstone contains large joints and fractures from folding that create high permeability, and it is confined by the Stanley Shale Formation.

\section{Boundary Conditions in the MODFLOW Model}

The MODFLOW groundwater-flow model solves the differential equation for groundwater flow as a boundary value problem. Numerical solutions of boundary value problems require the definition of mathematical boundary conditions to constrain the solution within the model grid. Boundary conditions in the MODFLOW groundwaterflow model represent the locations in the model grid where groundwater flows into or out of the model grid. The boundary conditions incorporated into the MODFLOW groundwater-flow model were a combination of specified 


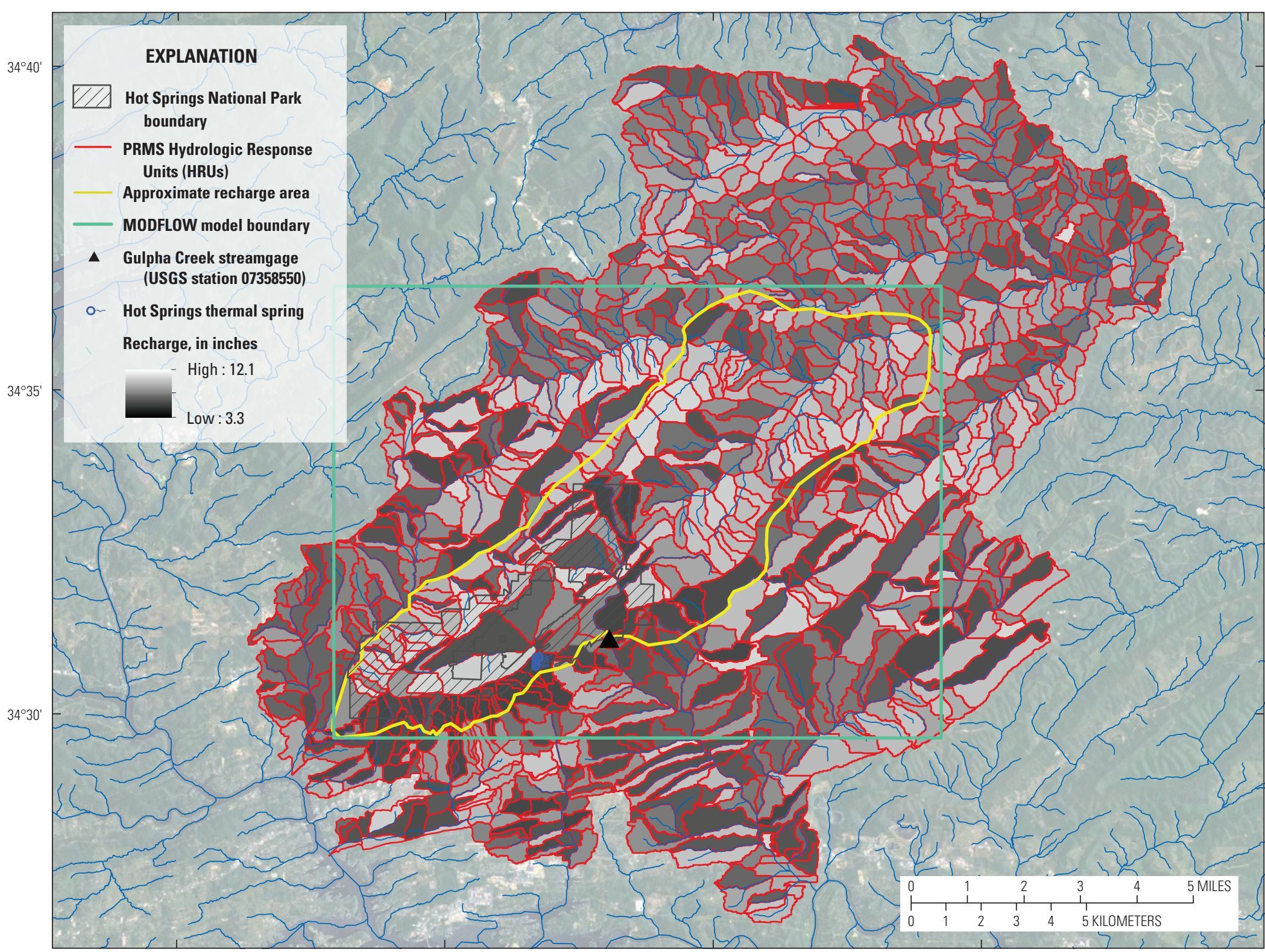

Map image is the intellectual property of Esri and is used herein under license Copyright $@ 2013$ Esri, i-cubed, GeoEye. All rights reserved.

Figure 6. Precipitation-Runoff Modeling System (PRMS)-simulated annual mean recharge in individual hydrologic response units (HRUs) for use in the groundwater-flow model of the Hot Springs National Park and surrounding area, Arkansas. 
Table 3. Simulated recharge values, obtained by using the Rorabaugh (RORA) code (Rutledge, 1998, 2000), for U.S. Geological Survey streamgages near the Hot Springs National Park and surrounding area, Arkansas.

\begin{tabular}{|c|c|c|c|}
\hline Streamgage name and station number ${ }^{1}$ & $\begin{array}{l}\text { Drainage area } \\
\text { (square miles) }\end{array}$ & $\begin{array}{l}\text { Period of } \\
\text { record }\end{array}$ & $\begin{array}{l}\text { Simulated annual mean recharge } \\
\text { (inches per year) }\end{array}$ \\
\hline Brushy Creek near Jessieville, Arkansas (07362656) & 17.8 & 2004-2007 & 14.1 \\
\hline $\begin{array}{l}\text { Whittington Creek at Tunnel Entrance at Hot Springs, Arkansas } \\
\text { (07358253) (see fig. 1) }\end{array}$ & 2.2 & 2009-2014 & 20.6 \\
\hline Alum Fork Saline River near Reform, Arkansas (07362587) & 27.0 & $1990-2014$ & 14.0 \\
\hline $\begin{array}{l}\text { Middle Fork Saline River near Owensville, Arkansas } \\
\quad(07362693)\end{array}$ & 93.9 & 2003-2007 & 9.0 \\
\hline $\begin{array}{l}\text { Hot Springs Creek downstream of Grand Avenue at Hot } \\
\text { Springs, Arkansas (07358284) (see fig. 1) }\end{array}$ & 4.2 & 2009-2014 & 24.5 \\
\hline
\end{tabular}

${ }^{1}$ From U.S. Geological Survey (2019c).

fluxes and head-dependent fluxes. The MODFLOW input files (Hart and Ikard, 2021) that implemented these boundary conditions included the following:

1. The Drain package (DRN), which simulated headdependent fluxes out of the model grid in one drain positioned in layer 1 at the coordinate of the thermal springs (fig. 9);

2. The River (RIV) package, which was used to assign the grid coordinates, riverbed conductance, and stages of river cells in layer 1 of the model grid (fig. 10) and was used to implement nonlinear, head-dependent fluxes into or out of river cells;

3. The Recharge $(\mathrm{RCH})$ package, which was used to define aerially distributed specified fluxes of recharge (fig. 11) into each grid cell in the top layer of the model grid; and

4. The General Head Boundary (GHB) package, which was used to implement head-dependent fluxes in the boundary cells around the perimeter of the model grid in all layers.

Every cell of the model grid was active except for the those in the bottom layer. Cells of the bottom layer were assigned as inactive cells to represent a zero-flux (no-flow) boundary condition.

General head boundary (GHB) conditions were implemented based on the linear relation between the calculated head in an active grid cell and a predefined reference head in an adjacent GHB cell. This relation is given in equation 1 and described in more detail by Harbaugh (2005). In equation 1 $Q$ is the GHB flux (in cubic feet per day), $C$ is the hydraulic conductance of the GHB grid cell (in feet squared per day) defined as the product of hydraulic conductivity and crosssectional area of the GHB cell divided by the flow path length between the active cell and GHB cell, $H$ (in feet) is the head in the active cell, which is calculated as a part of the MODFLOW groundwater-flow model solution, and $H_{o}$ (in feet) is a reference head assigned to the GHB cell and defined explicitly in the GHB package.

$$
Q=-C\left(H-H_{o}\right)
$$

In the groundwater-flow model, the reference heads in GHB cells were calculated separately from the MODFLOW solution (as described below) and were defined explicitly in the GHB package. According to equation 1, GHB flux is proportional to the difference in head between an active cell and an adjacent GHB cell and can be unidirectional or multidirectional. Because the GHB cells line the perimeter of the model grid in all layers, flux into or out of an adjacent active cell, quantified by equation 1, is analogous to groundwater flow into or out of the model grid. When the calculated head in the active cell is greater than the reference head in the GHB cell, GHB flux is directed from the active cell into the GHB cell and is analogous to groundwater flow out of the model grid. On the other hand, if the calculated head in the active cell is less than the reference head in the GHB cell, GHB flux is directed from the GHB cell into the active cell and is analogous to groundwater flow into the model grid. Alternatively, if the head in the active cell is equal to the head in the GHB cell, the GHB flux between the cells is zero and groundwater flow does not occur between the grid cells.

The reference heads in the GHB cells were computed by considering that the groundwater-flow system could be simplified in concept. Figure 12 shows this simplified concept of how recharge enters the groundwater-flow system, flows downgradient beneath a synclinal valley, and is heated along the flow path by the natural geothermal gradient. Deep, heated groundwater rises vertically to discharge at the 


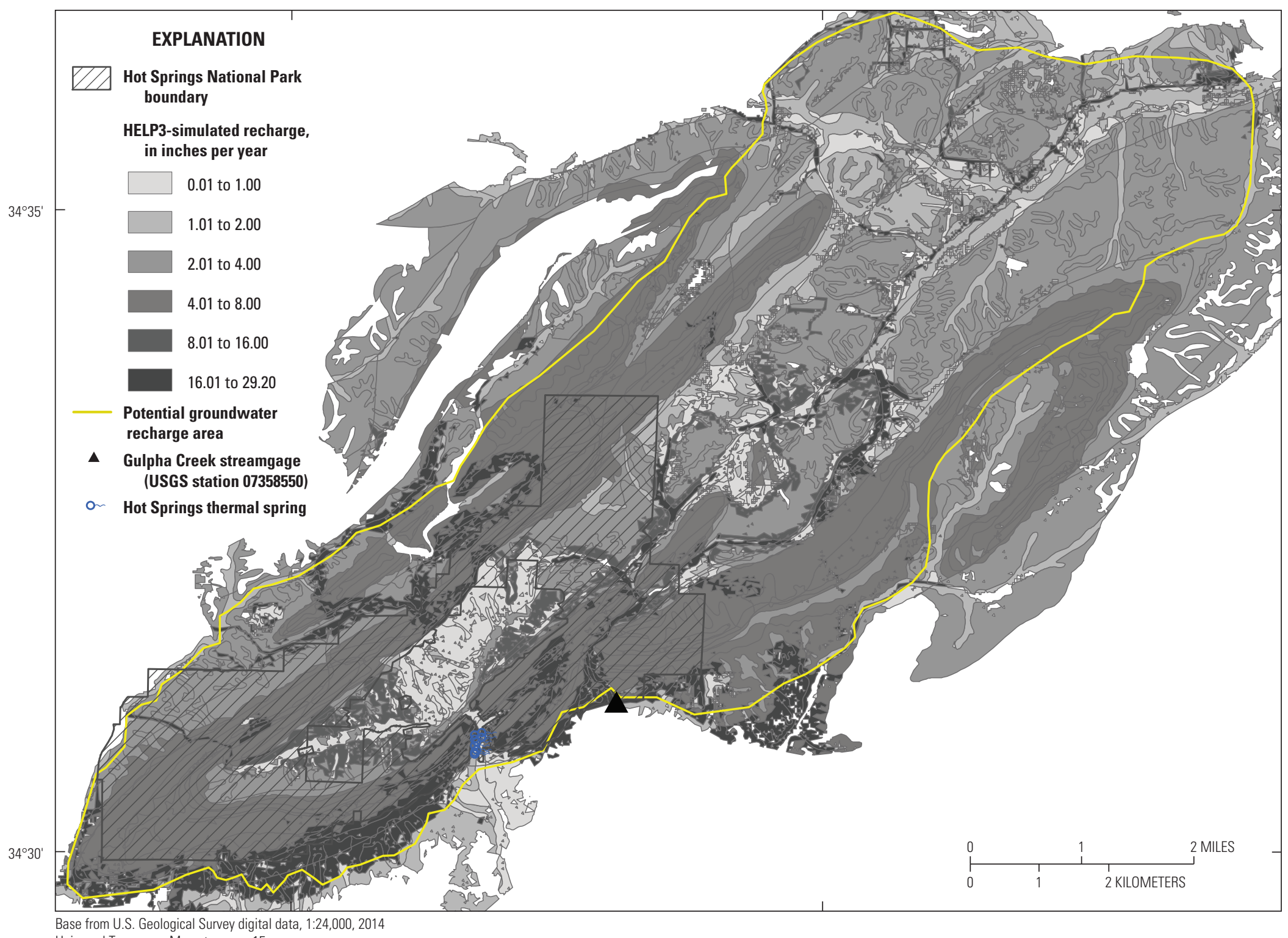

Base from U.S. Geological Survey digital data, 1:24,000, 2014

Figure 7. Recharge simulated by the Hydrologic Evaluation of Landfill Performance v. 3 (HELP3) model for the Hot Springs National Park and surrounding area, Arkansas. 


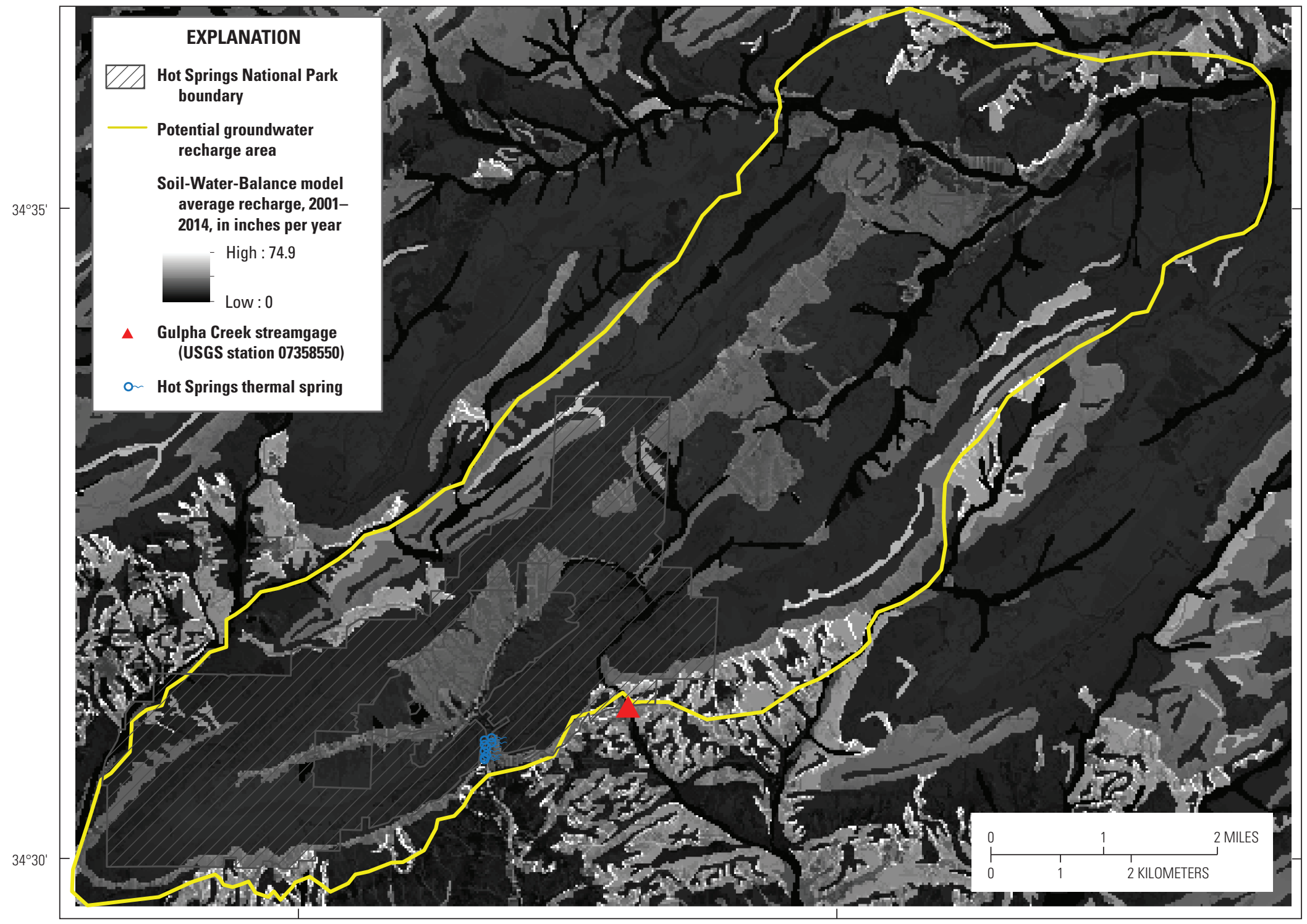

Base from U.S. Geological Survey digital data, 1:24,000, 2014

Universal Transverse Mercator, zone 15

Figure 8. Annual mean recharge simulated by the Soil-Water-Balance model for the Hot Springs National Park and surrounding area, Arkansas. 

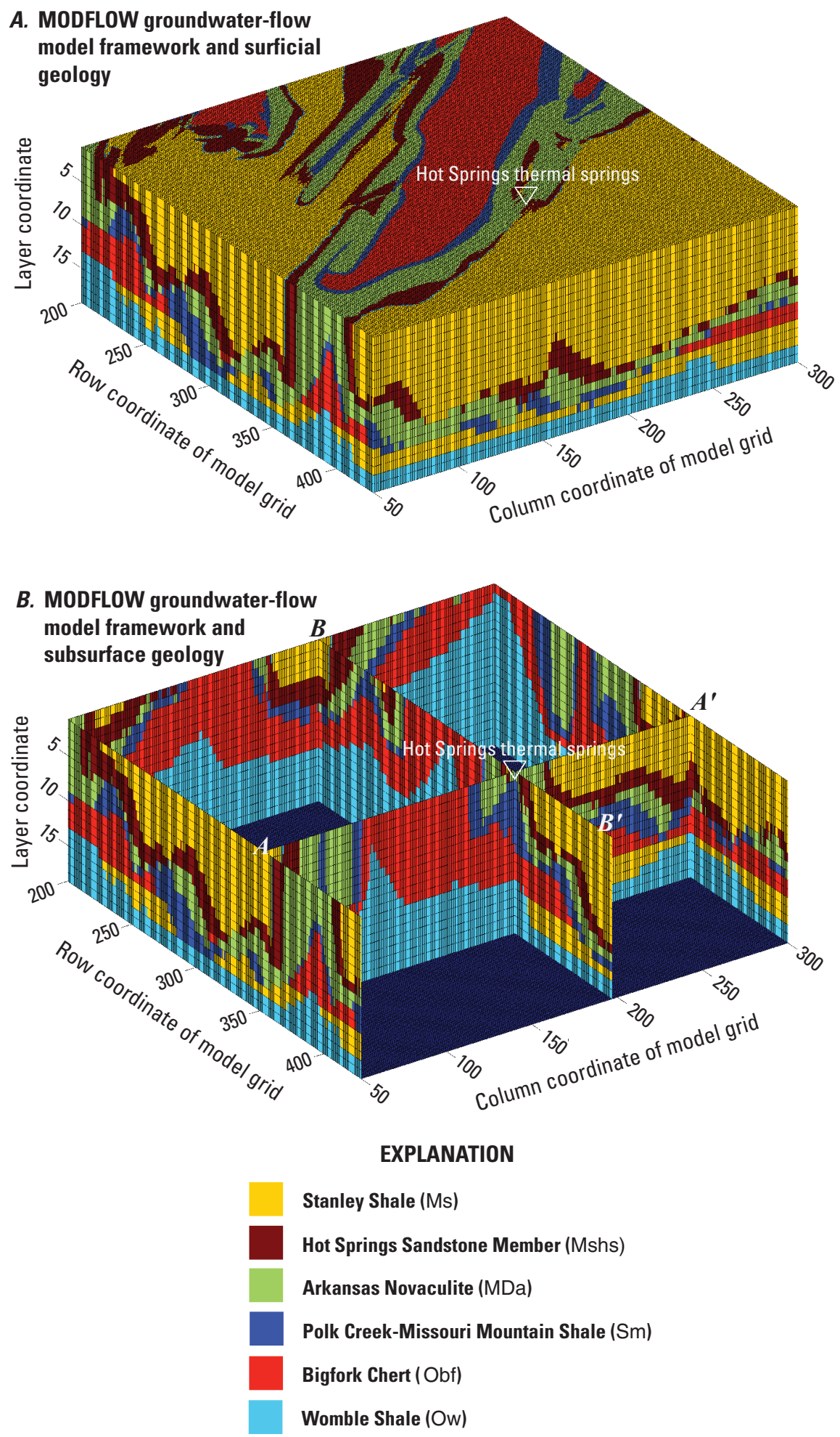

Figure 9. Three-dimensional hydrogeologic framework and model grid of the MODFLOW groundwater-flow model. The framework is shown over a subsection of the full model grid delineated by cross sections $A-A^{\prime}$ and $B-B^{\prime}$ (fig. 2). The location of the thermal springs' collection system is shown at the surface at model-grid coordinate $1,353,197$. A. MODFLOW groundwater-flow model framework showing surficial and subsurface geology. $B$. MODFLOW groundwater-flow model framework showing subsurface geology. 


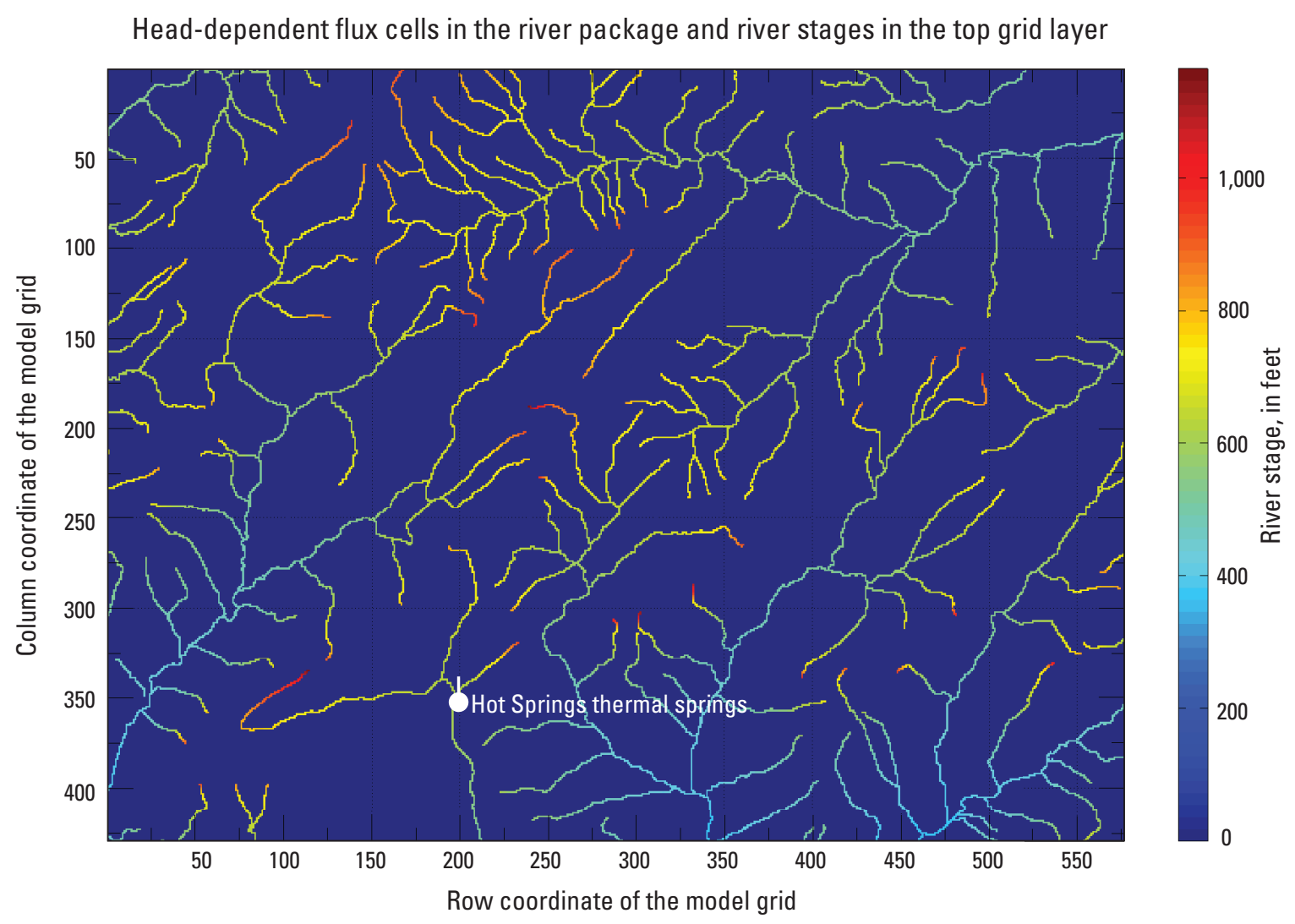

Note: River stage was assumed equal to the elevation of the riverbed.

Figure 10. River network (U.S. Geological Survey, 2019b) showing cells of the top layer of the model grid used as nonlinear head-dependent flux boundaries for the Hot Springs National Park study area, Arkansas. River cells are color-coded in terms of river stage, which was assumed equal to the elevation of the riverbed.

thermal springs (Bedinger and others, 1979). This simplified conceptual model was described mathematically by the principle of energy conservation to arrive at an equation to calculate the distribution of starting hydraulic heads in the model-grid cells and reference heads in GHB cells.

The principle of energy conservation was applied to quantify the total hydraulic head, $H_{T}$ (in feet, eq. 2) between two points at the locations of recharge (point 1, fig. 12) and spring discharge (point 2, fig. 12). Total hydraulic head is equal to the summation of the pressure-head, velocity-head, and elevation-head components. These components are directly related in the Bernoulli equation (eq. 2) (Munson and others, 2006) to the hydrostatic pore-fluid pressure $P$ (in pounds per square foot), the pore-fluid velocity $V$ (in feet per second), and the elevation $z$ (in feet) at a given point in the subsurface, respectively. Total head in equation 2 is in reference to fresh groundwater having a specific gravity given by the product of its density, $\rho$ (in pounds per cubic foot), and gravitational acceleration, $g$ (in feet per square second).

$$
H_{T}=\frac{P}{\rho g}+\frac{V^{2}}{2 g}+z
$$

The hydraulic heads at the locations of recharge (point 1 , fig. 12) and spring discharge (point 2, fig. 12) were related by the principle of energy conservation in equation 3 .

$$
\frac{P_{1}}{\rho g}+\frac{V_{1}^{2}}{2 g}+z_{1}=\frac{P_{2}}{\rho g}+\frac{V_{2}^{2}}{2 g}+z_{2}
$$

The velocity heads were neglected and omitted from both sides of equation 3 . The hydraulic pressure at the thermal springs, $P_{2}$ (in pounds per square foot), was assumed to be atmospheric gage pressure ( 0 pounds per square foot; $1 \mathrm{~b} / \mathrm{ft}^{2}$ ) and was omitted from the right-hand side of equation 3 . These simplifications resulted in equation 4 , which relates the hydrostatic pore pressure at the location of recharge to the specific gravity of the groundwater and the elevation difference, $\Delta z$ (in feet), between the locations of recharge and spring discharge, set equal to $420 \mathrm{ft}$ (Bedinger and others, 1979).

$$
P_{1}=\rho g\left(z_{2}-z_{1}\right)=\rho g \Delta z
$$

The total pressure driving groundwater flow through the system, $P_{T}$ (in pounds per square foot), was assumed to be a combined result of lithostatic overburden pressure, $P_{L}$ (in 

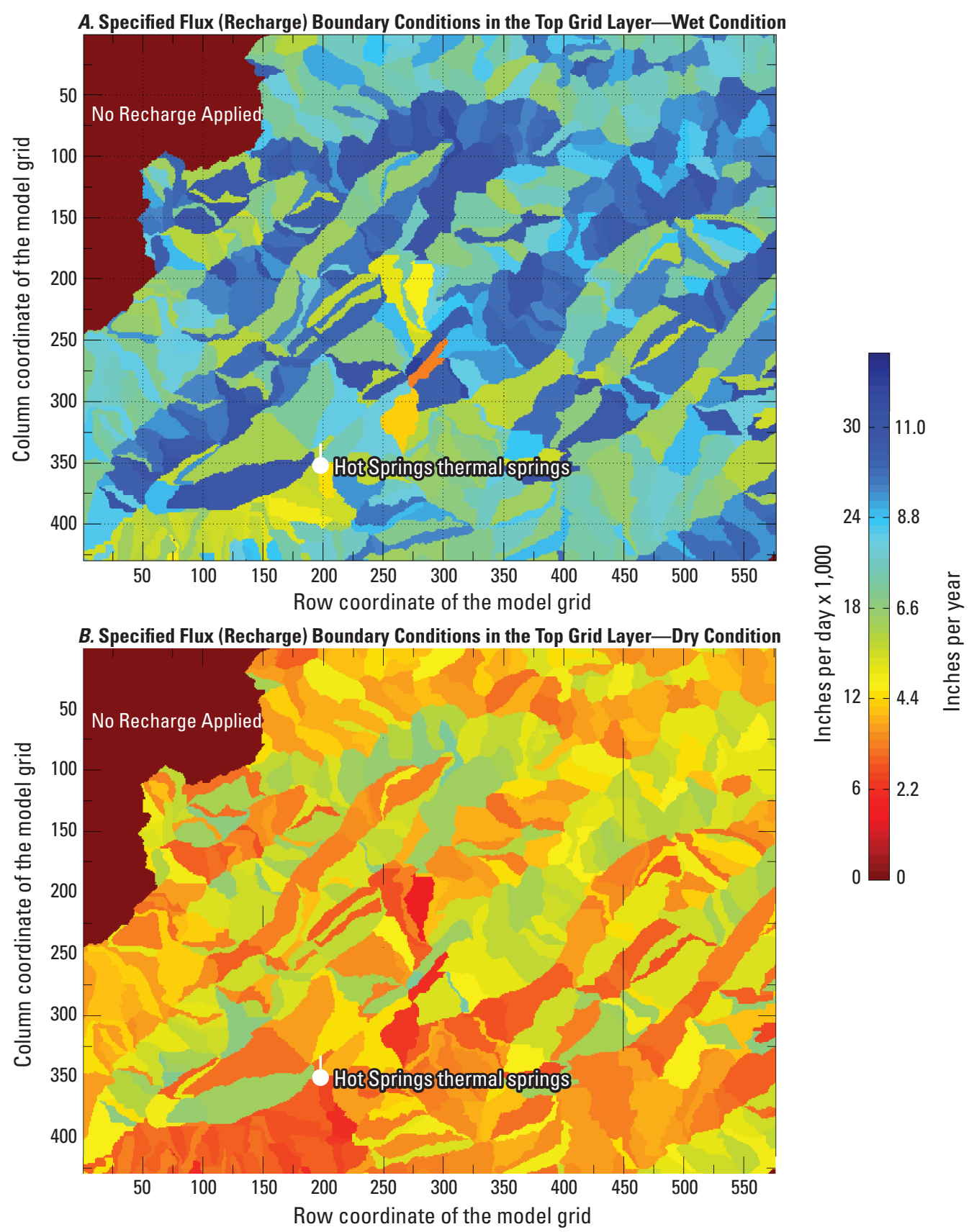

Figure 11. Examples of Precipitation-Runoff Modeling System (PRMS)-simulated recharge applied to the top layer of the MODFLOW model grid for the Hot Springs National Park study area, Arkansas. $A$. PRMS-simulated recharge for a relatively "wet" year when a comparatively large volume of recharge was applied to the MODFLOW groundwater-flow model. This recharge grid was used to manually calibrate the MODFLOW groundwater-flow model. $B$. PRMS-simulated recharge for a relatively "dry" year when a comparatively small volume of recharge was applied to the MODFLOW groundwater-flow model. 


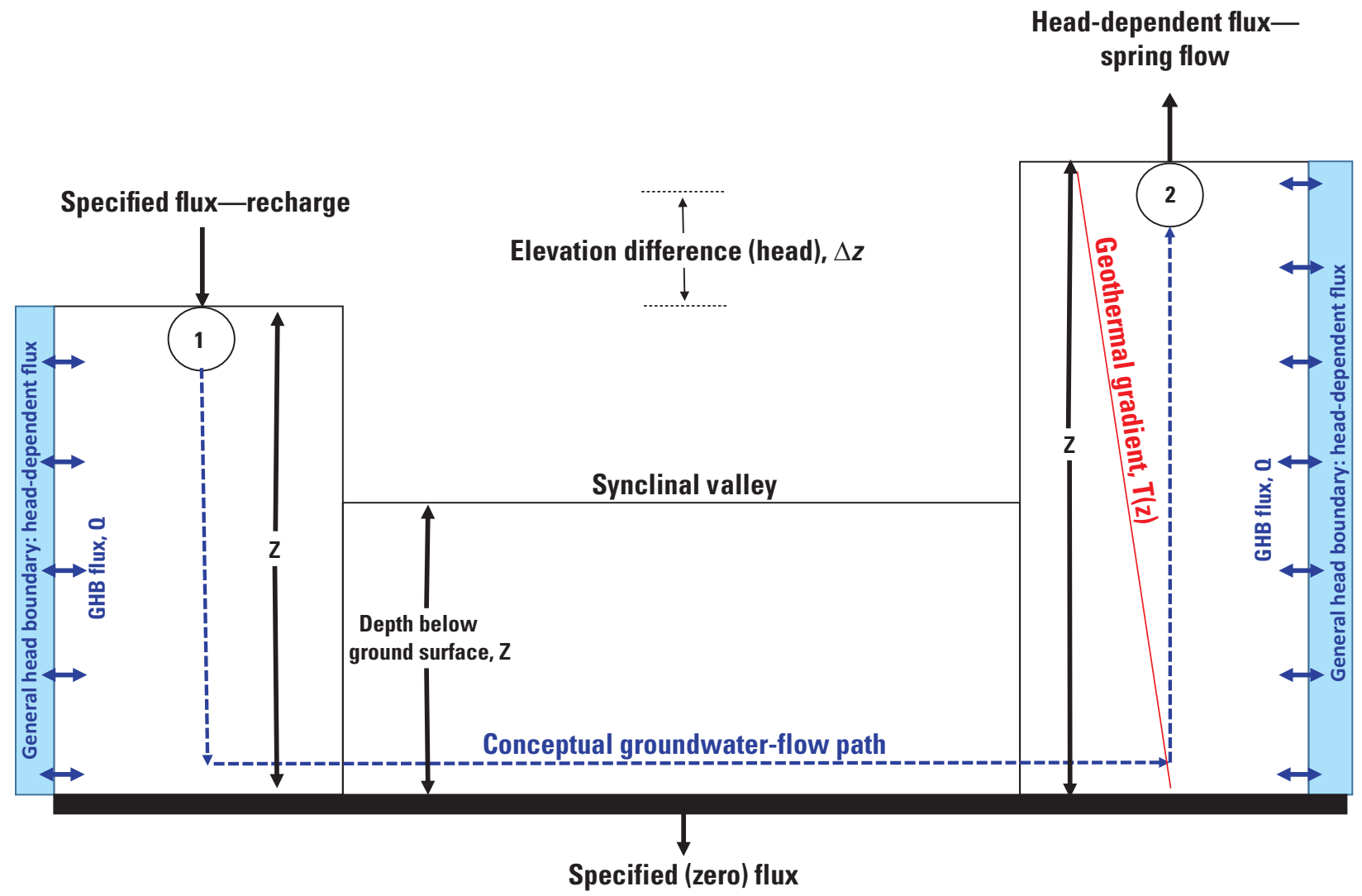

Figure 12. Simplified diagram of the conceptual groundwater-flow path between the recharge location and the thermal springs in the MODFLOW groundwater-flow model, from which the starting heads in each cell of the model grid and the reference heads in the general head boundary cells were computed. This illustration represents the specified-flux (no-flow) boundary condition applied to the base of the model grid and the head-dependent flux boundary conditions applied to the general head boundary cells around the perimeter of the model grid.

pounds per square foot; an analog for the effective stress of the rock exoskeleton), and the hydrostatic pore-fluid pressure, $P_{H}$ (in pounds per square foot), exerted by the groundwater in the pore space, as shown in equation 5 .

$$
P_{T}=\left(P_{L}+P_{H}\right)
$$

Lithostatic pressure variations at depth were assumed to vary linearly in accordance with equation 4 and were calculated by substituting the depth of any given model-grid cell beneath the ground surface, $Z$ (feet), in place of the elevation difference, $\Delta z$, as shown in equation 6 . This component of the total pressure was computed as a function of the bulk density of the rock overburden, $\rho_{B}$ (in pounds per cubic foot), at any given depth, which in turn was computed as $\rho_{B}=\rho_{r}(1-\phi)$, where $\phi$ is the porosity (unitless; table 4), and $\rho_{r}$ (in pounds per cubic foot) is the particle density of rock formations in the framework.

$$
P_{L}=(1-\phi) \rho_{r} g Z=\rho_{B} g Z
$$

The bulk density at each depth was computed with equation 7 as a depth-weighted average of bulk density of every model-grid cell above a given depth in the model grid, where $i$ is a summation index corresponding to the layer.

$$
\rho_{B}=\frac{\sum_{i}^{1}\left[(1-\phi) \rho_{r} Z\right]_{i}}{\sum_{i}^{1} Z_{i}}
$$

The hydrostatic component of total pressure at depth was accounted for by weighting equation 4 by the porosity, and was calculated with equation 8 from the temperaturedependent fluid density, $\rho_{f}\left(T_{z}\right)$ (in pounds per cubic foot), depth beneath the ground surface, and depth-dependent temperature, $T_{z}$ (in degrees Celsius), to represent the effects of the geothermal gradient on the pressure-head distribution.

$$
P_{H}=\phi \rho_{f}\left(T_{z}\right) g Z
$$

The geothermal gradient, $d T_{z} / d z$ (in degrees Celsius per foot), was calculated with equation 9 from the average surface air temperature, $T_{a}=17.4{ }^{\circ} \mathrm{C}$, reported by Kresse and Hays (2009), the maximum groundwater temperature, $T_{\max }=66.6^{\circ} \mathrm{C}$, 
Table 4. Summary of calibrated model parameters by geologic formation in the Hot Springs National Park and surrounding area, Arkansas.

[hk, horizontal hydraulic conductivity; ft/d, foot per day; vka, vertical hydraulic conductivity; lb/ $\mathrm{ft}^{3}$, pound per cubic foot; $\mathrm{ft}^{2} / \mathrm{d}$, foot squared per day; GHB, general head boundary]

\begin{tabular}{|c|c|c|c|c|c|c|c|}
\hline \multirow[b]{2}{*}{ Parameter } & \multicolumn{7}{|c|}{ Formation name (and geologic-map abbreviation) } \\
\hline & $\begin{array}{c}\text { Polk Creek- } \\
\text { Missouri } \\
\text { Mountain Shale } \\
(\mathrm{Sm})\end{array}$ & $\begin{array}{c}\text { Womble } \\
\text { Shale } \\
\text { (Ow) }\end{array}$ & $\begin{array}{c}\text { Arkansas } \\
\text { Novaculite } \\
\text { (MDa) }\end{array}$ & $\begin{array}{l}\text { Stanley } \\
\text { Shale } \\
\text { (Ms) }\end{array}$ & $\begin{array}{c}\text { Bigfork } \\
\text { Chert } \\
\text { (Obf) }\end{array}$ & $\begin{array}{l}\text { Hot Springs } \\
\text { Sandstone } \\
\text { (Mshs) }\end{array}$ & $\begin{array}{c}\text { Vertical } \\
\text { fault }\end{array}$ \\
\hline hk (ft/d) & $1.000 \times 10^{-4}$ & $1.000 \times 10^{-5}$ & 0.115 & $1.000 \times 10^{-4}$ & 2.3 & 3 & 100 \\
\hline vka $(\mathrm{ft} / \mathrm{d})$ & $1.750 \times 10^{-4}$ & $1.750 \times 10^{-5}$ & 0.2013 & $1.750 \times 10^{-4}$ & 4.025 & 5.25 & 175 \\
\hline Bulk density $\left(\mathrm{lb} / \mathrm{ft}^{3}\right)$ & 99.9 & 99.9 & 167.9 & 99.9 & 167.9 & 143.6 & 62.4 \\
\hline $\begin{array}{l}\text { Riverbed conduc- } \\
\text { tance }\left(\mathrm{ft}^{2} / \mathrm{d}\right)\end{array}$ & 4 & 4 & 4 & 4 & 4 & 4 & 4 \\
\hline $\begin{array}{l}\text { Drain conductance } \\
\quad\left(\mathrm{ft}^{2} / \mathrm{d}\right)\end{array}$ & 1,000 & 1,000 & 1,000 & 1,000 & 1,000 & 1,000 & 1,000 \\
\hline
\end{tabular}

and the maximum flow depth, $Z_{\max }=7,500 \mathrm{ft}$, estimated by Bedinger and others (1979). The temperature distribution throughout the model grid was calculated as a function of the geothermal gradient and the depth of any given grid cell by using equation 10 .

$$
\begin{gathered}
\frac{d T_{z}}{d Z}=\frac{T_{\max }-T_{a}}{Z_{\max }} \\
T(Z)=T_{a}+\frac{d T}{d Z} Z
\end{gathered}
$$

The temperature in each cell of the model grid was then used to calculate the fluid density in each cell by using the linear relation between temperature-dependent fluid density and depth-dependent temperature (for $T_{z}$ in degrees Kelvin $[\mathrm{K}]$ ) using equation 11. This relation was approximated from a linear regression of data tabulated by Munson and others (2006) for temperatures in the range of $273.15 \mathrm{~K}\left(0{ }^{\circ} \mathrm{C}\right)$ to $373.15 \mathrm{~K}$ $\left(100^{\circ} \mathrm{C}\right)$ and has a corresponding coefficient of determination $\left(\mathrm{R}^{2}\right)$ of 0.9810 .

$$
\rho_{f}\left(T_{z}\right)=1,148.6-0.5025 T_{z}
$$

Finally, the initial starting head in each model-grid cell was derived by substituting equations 6 and 8 into their respective terms in equation 5 and simplifying the result. This substitution and simplification resulted in equation 12, where $H_{P}$ (feet) is essentially a pressure head. The starting hydraulic heads calculated with equation 12 were computed as a function of the geothermal gradient, lithostatic overburden pressure, and hydrostatic pore-fluid pressure, and varied throughout the model grid between a minimum of $444.6 \mathrm{ft}$ and a maximum of 2,750.8 ft, around a mean value of 2,160.5 ft. For comparison, the maximum elevation of the top layer of the model grid was $1,410.3 \mathrm{ft}$, and the maximum depth of the model grid was $-9,151.6 \mathrm{ft}$, corresponding to a total vertical relief of 10,561.9 ft between the top-most and bottom-most cells of the model grid. The distribution of the starting heads computed from this simplified model are shown in figure 13 beneath cross sections $A-A^{\prime}$ and $B-B^{\prime}$ (fig. 2).

$$
H_{P}=\Delta z\left[\frac{\rho_{B}}{\rho_{f}(T(Z))}+\phi\right]
$$

\section{Calibration of the MODFLOW Model}

The MODFLOW groundwater-flow model was manually calibrated to historical daily mean spring flows of $88,000 \mathrm{ft}^{3} / \mathrm{d}$ measured at the thermal springs collection system over a 12-year period of record from 1990-1995 and 1998-2005 (the collection system was inoperable between 1995 and 1998 and thermal spring flow was not measured). The model was only calibrated to measured spring flows. No attempt was made to calibrate the model to observed well heads because the only available observations were from wells completed in the first layer of the model grid at depths less than $200 \mathrm{ft}$ (fig. 1). Previous studies indicate that these wells are disconnected (in a hydraulic sense) from the deeper groundwater-flow system (Kresse and Hays, 2009). 


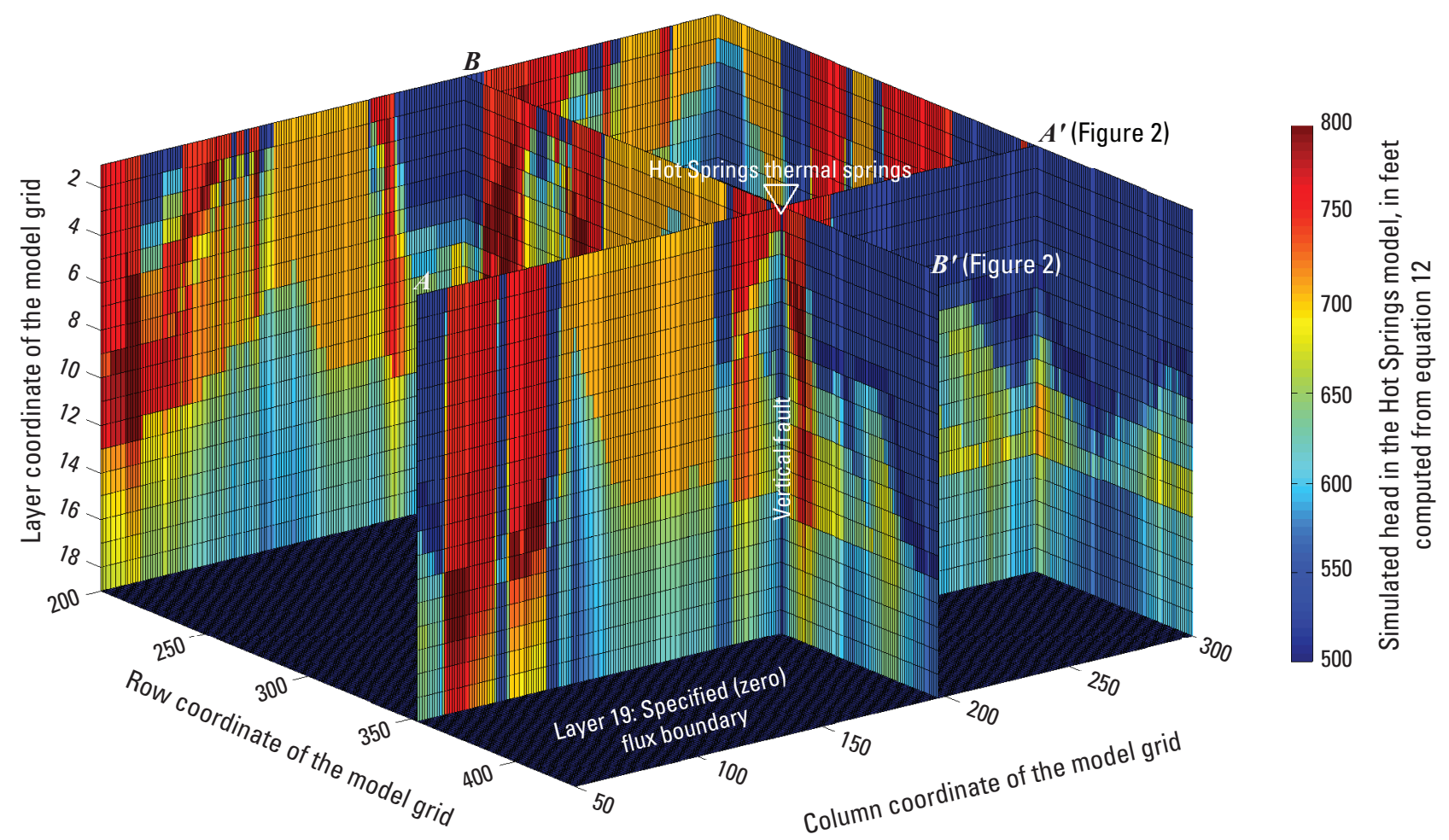

Figure 13. Distribution of starting heads in the model grid calculated from equation 12 and derived from the simplified conceptual model of the groundwater-flow system shown in figure 12 for the Hot Springs National Park and surrounding area, Arkansas.

The initial values of hydraulic properties of each rock formation in the framework were estimated from a combination of literature references cited herein and through use of the database of Saxton and Rawls (2006) to obtain reasonable estimates of bulk density, porosity, and horizontal and vertical hydraulic conductivity (hereinafter referred to as "hk" and "vka," respectively) of each rock formation. Bulk density and porosity estimates were not explicitly used in the MODFLOW model but were used to calculate the starting heads in active cells and the reference heads in GHB cells of the model grid. The manual calibration consisted of defining the starting heads and GHB heads in the model grid using equation 12, and then varying the hk and vka parameters of the rock formations, in addition to the river, drain, and GHB conductance parameters to achieve a close match between the observed and simulated mean daily spring flows at the thermal springs collection system. The vka parameter for each formation was quantified as a scaled multiple of the hk parameter, equal to vka $=1.75(\mathrm{hk})$, to emphasize vertical flow in the model. The final parameter values corresponding to the calibrated model are summarized in table 4.

The final hydraulic conductivity parameters for the Bigfork Chert and Arkansas Novaculite compare well with the ranges reported by Bedinger and others (1979) $(0.5-10$ feet per day $[\mathrm{ft} / \mathrm{d}]$ for the Bigfork Chert and a maximum of $1 \mathrm{ft} / \mathrm{d}$ for the Arkansas Novaculite); however, the parameter values for the Hot Springs Sandstone and shale formations are slightly larger than typical ranges reported in the literature to account for fracturing of the formations $\left(8.5 \times 10^{-5}-1.7 \mathrm{ft} / \mathrm{d}\right.$ for sandstone and $2.8 \times 10^{-8}-6 \times 10^{-4} \mathrm{ft} / \mathrm{d}$ for shales, as reported by Domenico and Schwartz [1990]). The final parameter values of the calibrated model (table 4) were subsequently used for sensitivity analysis, particle tracking using MODPATH, and predictive simulations using the PRMS-simulated recharge.

The calibrated-model solution consisted of the calculated hydraulic heads in the active cells of the model grid, calculated for one steady-state stress period of 34 years (1980-2014), and incorporated the PRMS-simulated recharge grid illustrated in figure $11 \mathrm{~A}$ (see also table 5) as the aerially distributed recharge. The calibrated model yielded simulated spring-flow rates of $85,102.7 \mathrm{ft}^{3} / \mathrm{d}$ (or about $1 \mathrm{ft}^{3} / \mathrm{s}$ ) at the thermal springs, which compared well to the calibration target of $88,000 \mathrm{ft}^{3} / \mathrm{d}$. The spring discharge simulated by the calibrated MODFLOW groundwater-flow model corresponded to a difference of $2,897.3 \mathrm{ft}^{3} / \mathrm{d}$ from the calibration target, and the calibrated model was characterized by a low mass balance of $1.36 \mathrm{ft}^{3} / \mathrm{d}$. The mass balance is an important indicator metric because the MODFLOW model must conserve mass. Mass imbalances will occur if the heads in the active model-grid cells were not stabilized during iterative calculations, which will result in head gradients that produce inconsistent fluxes into and out of the model grid. A poor mass balance is therefore a potential 
indicator of poor formulation of the hydrogeologic framework, large contrasts in physical properties between adjacent grid cells, large differences in discretization intervals between adjacent cells, or problems with definition of time steps and stress period lengths in transient models.

\section{Sensitivity of the MODFLOW Model}

A sensitivity analysis was performed on the calibrated MODFLOW groundwater-flow model. Sensitivity analysis was performed to evaluate the importance of hk and vka parameters, elevation head $(\Delta z)$ assumed in the simplified conceptual model (fig. 12), and the riverbed, drain, and GHB conductance parameters (table 4), for accurately simulating the well heads in modelgrid cells containing shallow wells (table 5) and the historical daily mean spring-flow rates at the thermal springs. The simulated well heads and spring flows are hereinafter referred to collectively as "simulated equivalents." Although the MODFLOW model was not calibrated to well heads (hence the large residuals in table 5), including them in the sensitivity analysis is informative and meaningful for making future improvements to the groundwater-flow model. The well heads are summarized in table 5 in terms of their USGS identification numbers (USGS, 2019c), model-grid coordinates, depths to water, observed and simulated values, and the residuals.

The sensitivities of each simulated equivalent to the parameter values were computed with equation 13. Equation 13 defines sensitivity as the ratio of the change in the $i^{\text {th }}$ simulated equivalent, denoted by the partial derivative $\partial y_{i}$, to a corresponding small incremented change in the $j^{\text {th }}$ parameter value denoted by the partial derivative $\partial P_{j}$. Sensitivity represents the slope of a plot of a simulated equivalent $y_{i}$ relative to one parameter value, $P_{j}$, and indicates approximately how much a simulated equivalent would change if the parameter were to change (Hill and Tiedeman, 2007). Sensitivity therefore represents a quantitative estimation of the importance of a given observation, such as well heads or spring flow, to the estimation of the parameter value using the model, and vice versa. As noted by Reilly and Harbaugh (2004), the most sensitive parameters will be the most important for causing the model to match observed values of the simulated equivalents, assuming parameters are not correlated.

$$
\text { Sensitivity }(S)=\frac{\text { Change in Simulated Observation }}{\text { Change in Parameter Value }}=\frac{\partial y_{i}}{\partial P_{j}}
$$

In the MODFLOW groundwater-flow model, the number of simulated equivalents was $i=10$ (simulated well heads and spring flow), and there were $j=7$ parameters each for hk and vka (for the six rock formations and the vertical fault) and $j=4$ parameters corresponding to the elevation head and the riverbed, drain, and GHB conductance. A forward and backward parameter perturbation process was completed by individually and sequentially perturbing the values of each parameter by 1 percent of the calibration value, and then subsequently performing a model simulation with all other parameter values maintained unaltered

Table 5. Summary of hydraulic heads in wells (fig. 1) in the Hot Springs National Park and surrounding area, Arkansas.

[USGS, U.S. Geological Survey; ft, foot; NAVD 88, North American Vertical Datum of 1988]

\begin{tabular}{lccccccrrr}
\hline $\begin{array}{c}\text { Hydraulic } \\
\text { head }\end{array}$ & $\begin{array}{c}\text { USGS well identifi- } \\
\text { cation number }\end{array}$ & $\begin{array}{c}\text { Model- } \\
\text { grid layer }\end{array}$ & $\begin{array}{c}\text { Model- } \\
\text { grid row }\end{array}$ & $\begin{array}{c}\text { Model- } \\
\text { grid } \\
\text { column }\end{array}$ & $\begin{array}{c}\text { Elevation } \\
\text { (ft, } \\
\text { NAVD 88) }\end{array}$ & $\begin{array}{c}\text { Depth to } \\
\text { water } \\
\text { (ft) }\end{array}$ & $\begin{array}{c}\text { observed } \\
\text { value }\end{array}$ & $\begin{array}{c}\text { Simulated } \\
\text { value }\end{array}$ & Residual \\
\hline H1 & 343048093030401 & 1 & 358 & 205 & 751.2 & 121.6 & 629.5 & 824.5 & 195.0 \\
H2 & 343204093005501 & 1 & 280 & 314 & 881.5 & 122.7 & 758.7 & 848.3 & 89.6 \\
H3 & 343206093044101 & 1 & 278 & 122 & 583.2 & 8.2 & 575.0 & 824.3 & 249.3 \\
H4 & 343255092593601 & 1 & 228 & 381 & 801.3 & 52.0 & 749.3 & $1,757.8$ & $1,008.5$ \\
H5 & 343257092593601 & 1 & 225 & 381 & 759.3 & 27.8 & 731.6 & $2,441.1$ & $1,709.5$ \\
H6 & 343312093013201 & 1 & 210 & 283 & 718.7 & 27.0 & 691.6 & 796.3 & 104.7 \\
H7 & 343330092591101 & 1 & 192 & 403 & 670.2 & 24.2 & 646.0 & 783.9 & 137.9 \\
H8 & 343350093005901 & 1 & 172 & 311 & 787.7 & 76.4 & 711.3 & 793.6 & 82.3 \\
H9 & 343518092591701 & 1 & 181 & 397 & 625.1 & 39.9 & 585.2 & 756.3 & 171.1 \\
Q & 7358280 & 1 & 353 & 197 & 609.9 & 0.0 & $88,000.0$ & $85,102.7$ & $-2,897.3$ \\
\hline
\end{tabular}

${ }^{1}$ From USGS (2019c).

${ }^{2}$ Data represent average depth to water obtained from USGS (2019c) between September 1, 2012, and September 15, 2015. 
from their calibration values. After perturbing all parameter values in this manner, sensitivities were then calculated by centered finite differences using equation 14, where the term $Y_{i}$ $\left(P_{j}+\Delta P\right)$ represents the $i^{\text {th }}$ simulated equivalent obtained from forward perturbation of the $j^{\text {th }}$ parameter value, and the term $Y_{i}$ $\left(P_{j}-\Delta P\right)$ represents the $i^{\text {th }}$ simulated equivalent obtained from backward perturbation. The term $\Delta P$ represents the difference ( \pm 1 percent) between the perturbed and the baseline calibrated value for all forward and backward perturbations, respectively.

$$
S=\frac{Y_{i}\left(P_{j}+\Delta P\right)-Y_{i}\left(P_{j}-\Delta P\right)}{2 \Delta P}
$$

Parameter sensitivity for the MODFLOW model is illustrated by color-shaded sensitivity matrices in figure 14 . Figure $14 A$ is the sensitivity matrix computed for the hk parameter, figure $14 B$ is the sensitivity matrix computed for the vka parameter, and figure $14 C$ is the sensitivity matrix computed for the elevation head and riverbed, drain, and GHB and drain conductance parameters. The simulated equivalents are represented along the vertical axis of each sensitivity matrix, and the parameters are represented along the horizontal axis (by their geologic map abbreviations; see table 4). The colors represent the logarithms of the absolute values of the sensitivity, $\log _{10}|\mathrm{~S}|$, calculated from equation 14 .

For any given rock formation, a high degree of sensitivity of a simulated equivalent to the formation parameter is indicated by shades of yellow-red (for large positive sensitivity, where red indicates greater sensitivity than yellow) and medium-dark blue (for large negative sensitivity, where darker shades indicate greater sensitivity). Large positive or negative $\log _{10}|\mathrm{~S}|$ values indicate that the simulated equivalents respectively increase or decrease substantially for a corresponding small change in the parameter value. In other words, a high degree of sensitivity indicates the parameter is important for accurately simulating the particular observation, and therefore the observation is likely to be important with respect to accurately estimating the value of the parameter. Conversely, parameter insensitivity is indicated by shades of light blue and $\log _{10}|\mathrm{~S}|$ values approximately equal to zero. Low sensitivity implies that the change in a simulated equivalent is small, or possibly even zero, for a corresponding large change in the parameter value. Thus, the observation contributes very little to estimating the parameter, and the parameter is not overly important with respect to adequately simulating the given observation.

The calculated parameter sensitivities ranged from low to high sensitivity. With respect to the hk parameter, the simulated equivalent spring flows were most sensitive to the hk of the Womble Shale (Ow) $\left(\log _{10}|\mathrm{~S}|=7.0\right)$, Polk CreekMissouri Mountain Shale $(\mathrm{Sm})\left(\log _{10}|\mathrm{~S}|=-6.7\right)$, and Arkansas Novaculite (MDa) $\left(\log _{10}|\mathrm{~S}|=6.5\right)$ and were least sensitive to hk of the vertical fault $\left(\log _{10}|S|=-0.5\right)$. In comparison, the simulated equivalent well heads were most sensitive to the hk of the Polk Creek-Missouri Mountain Shale (the mean value of $\log _{10}|\mathrm{~S}|$ for all simulated equivalent well heads H1-H9 was
8.9) and the least sensitive to the vertical fault (the mean value of $\log _{10}|\mathrm{~S}|$ for all simulated equivalent well heads H1-H9 was $-0.9)$. Simulated equivalent well heads $\mathrm{H} 2$ and $\mathrm{H} 3$ showed the greatest sensitivity to hk of the fault $\left(\log _{10}|\mathrm{~S}|=-4.3\right)$.

The simulated equivalent spring flows $\left(\mathrm{Q}_{\mathrm{s}}\right.$, fig. 14) were more sensitive to vka compared to hk, and simulated equivalent well heads were generally less sensitive to vka compared to hk. In particular, the simulated equivalent spring flows were most sensitive to vka of the Polk Creek-Missouri Mountain Shale ( $\left.\log _{10}|\mathrm{~S}|=11.2\right)$, Womble Shale $\left(\log _{10}|\mathrm{~S}|=10.2\right)$, and Arkansas Novaculite $\left(\log _{10}|\mathrm{~S}|=9.9\right)$ and least sensitive to vka of the vertical fault $\left(\log _{10}|\mathrm{~S}|=3.8\right)$. The simulated equivalent well heads were most sensitive to the vka of the Polk CreekMissouri Mountain Shale (the mean value of $\log _{10}|\mathrm{~S}|$ for all simulated equivalents $\mathrm{H} 1-\mathrm{H} 9$ was 8.3 ) and were least sensitive to the vka of the vertical fault (the mean value of $\log _{10}|\mathrm{~S}|$ for all simulated equivalents $\mathrm{H} 1-\mathrm{H} 9$ was 0.1 ).

With respect to the two formations - the Arkansas Novaculite and the Bigfork Chert - theorized to convey groundwater from the recharge location to the thermal springs, the MODFLOW model indicates that simulated equivalent spring flows were more sensitive to the vka and hk parameters of the Arkansas Novaculite $\left(\log _{10}|\mathrm{~S}|=6.5\right.$ and 9.9, respectively) compared to the vka and hk parameters of the Bigfork Chert $\left(\log _{10}|\mathrm{~S}|=3.3\right.$ and 5.8, respectively). Simulated equivalent well heads and spring flows were both relatively insensitive to the emplacement of the fault within the framework. The simulated equivalent well heads were relatively insensitive to the elevation-head parameter as well as the drain and GHB conductance but were moderately sensitive to the riverbed conductance (fig. 14C). Simulated equivalent spring flows were also insensitive to the elevation head $\left(\log _{10}|\mathrm{~S}|=-2.3\right)$, drain conductance $\left(\log _{10}|\mathrm{~S}|=1.5\right)$, and the GHB conductance $\left(\log _{10}|\mathrm{~S}|=0\right)$ but demonstrated higher sensitivity to the riverbed conductance $\left(\log _{10}|\mathrm{~S}|=4.1\right)$.

\section{Particle Tracking}

Particle-tracking simulations were performed on the MODFLOW model by using MODPATH version 6 (Pollock, 2012). Particle tracking was performed in both the forward and backward directions to delineate the thermal springs recharge areas inherent within the model framework. Recharge areas were delineated by introducing a single particle into each cell in layer 1 of the model grid and recording the origin and terminal grid coordinates of the particle path lines. The lateral distances between the terminal grid coordinates of the path lines and the grid coordinate of the thermal springs were computed with equation 15 , where $d$ is the number of grid cells between the terminal row and column coordinates of the path line (given by $y$ and $x$, respectively) and the coordinate of the thermal springs in the model grid $(1,353,197)$.

$$
d=\left[(y-353)^{2}+(x-197)^{2}\right]^{1 / 2}
$$




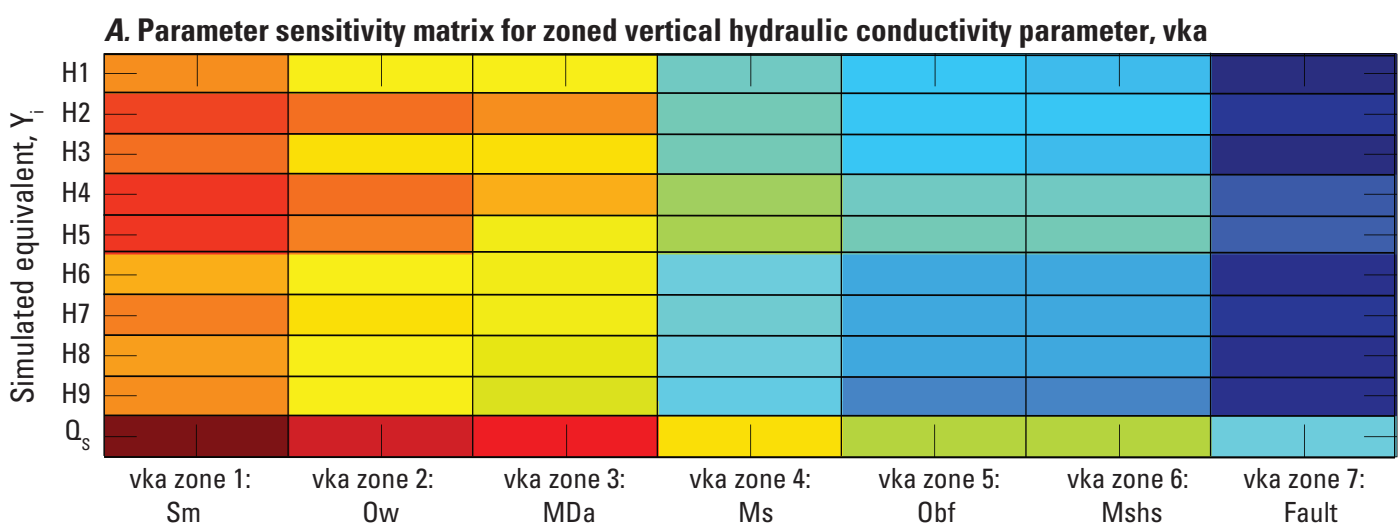

B. Parameter sensitivity matrix for zoned horizontal hydraulic conductivity parameter, hk

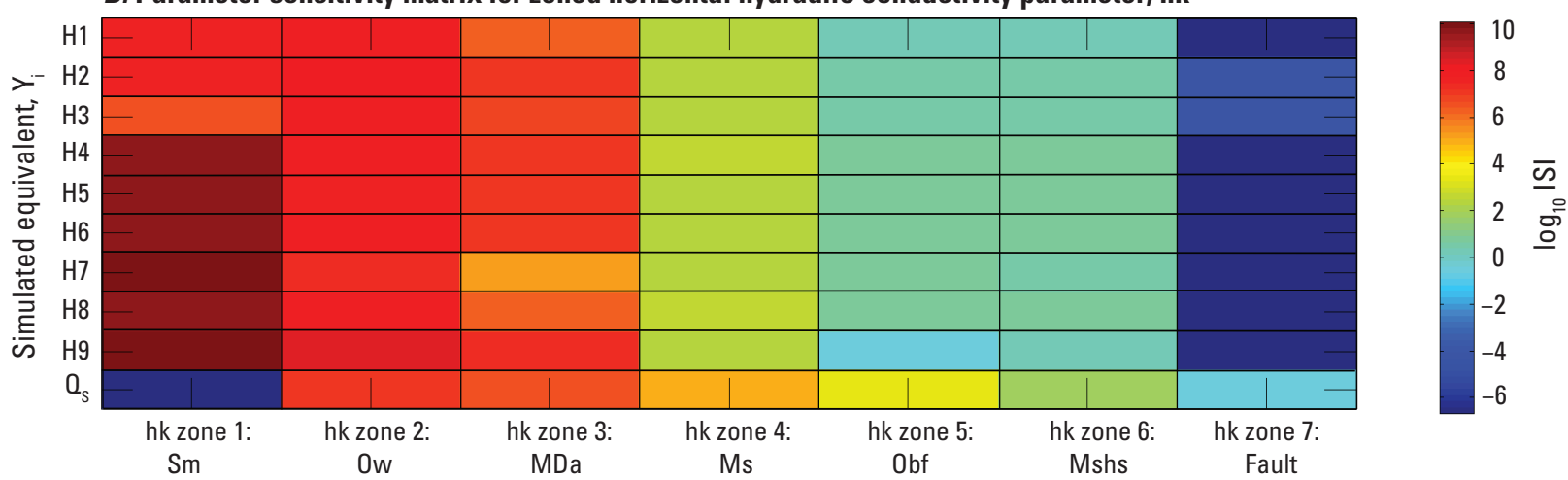

C. Parameter sensitivity matrix for elevation head, and river, ghb, and drain conductance

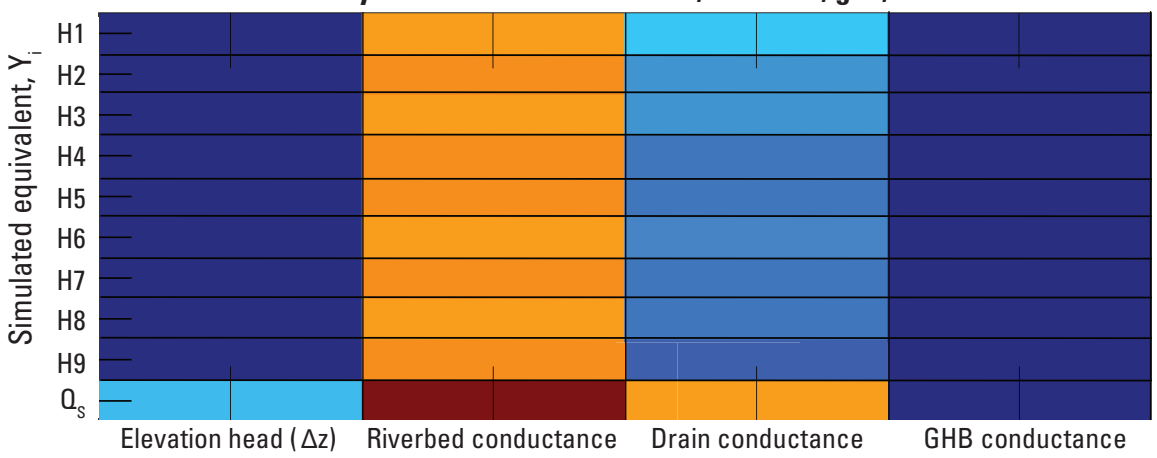

(eq. 12)

Figure 14. Sensitivity matrices showing the sensitivity of simulated equivalents $\left(y_{i}\right)$ to parameter values for the Hot Springs National Park and surrounding area, Arkansas. A. Sensitivity matrix for the horizontal hydraulic conductivity (hk) parameter. B. Sensitivity matrix for the vertical hydraulic conductivity (vka) parameter. $C$. Sensitivity matrix for elevation head (fig. 12 and eq. 12) and riverbed, drain, and general head boundary (GHB) conductance. Geologic map abbreviations are used to represent the following formations: Polk Creek-Missouri Mountain Shale (Sm), Womble Shale (Ow), Arkansas Novaculite (MDa), Stanley Shale (Ms), Bigfork Chert (Obf), and Hot Springs Sandstone (Mshs).

The distances calculated with equation 15 were plotted at the origin coordinate of the path lines, kriged, and then contoured to produce maps showing the number of model-grid cells between the terminal point and the thermal springs. This method does not account for vertical distance traveled by the particle, which could be substantial; however, the lateral distances shown in forward and backward particle-tracking maps in figure 15 enabled the identification of localized areas in the framework that may serve to recharge the thermal springs. The forward particle-tracking map shown in figure $15 \mathrm{~A}$ indicates that one predominant area of recharge (Recharge Area A) is to the southwest of the thermal springs, corresponding to a location where the dominant lithologies are the Arkansas Novaculite, Hot Springs Sandstone, and Bigfork Chert. The backward particle-tracking map shown in figure $15 B$ indicates a localized area of recharge (Recharge Area B) to the northeast 

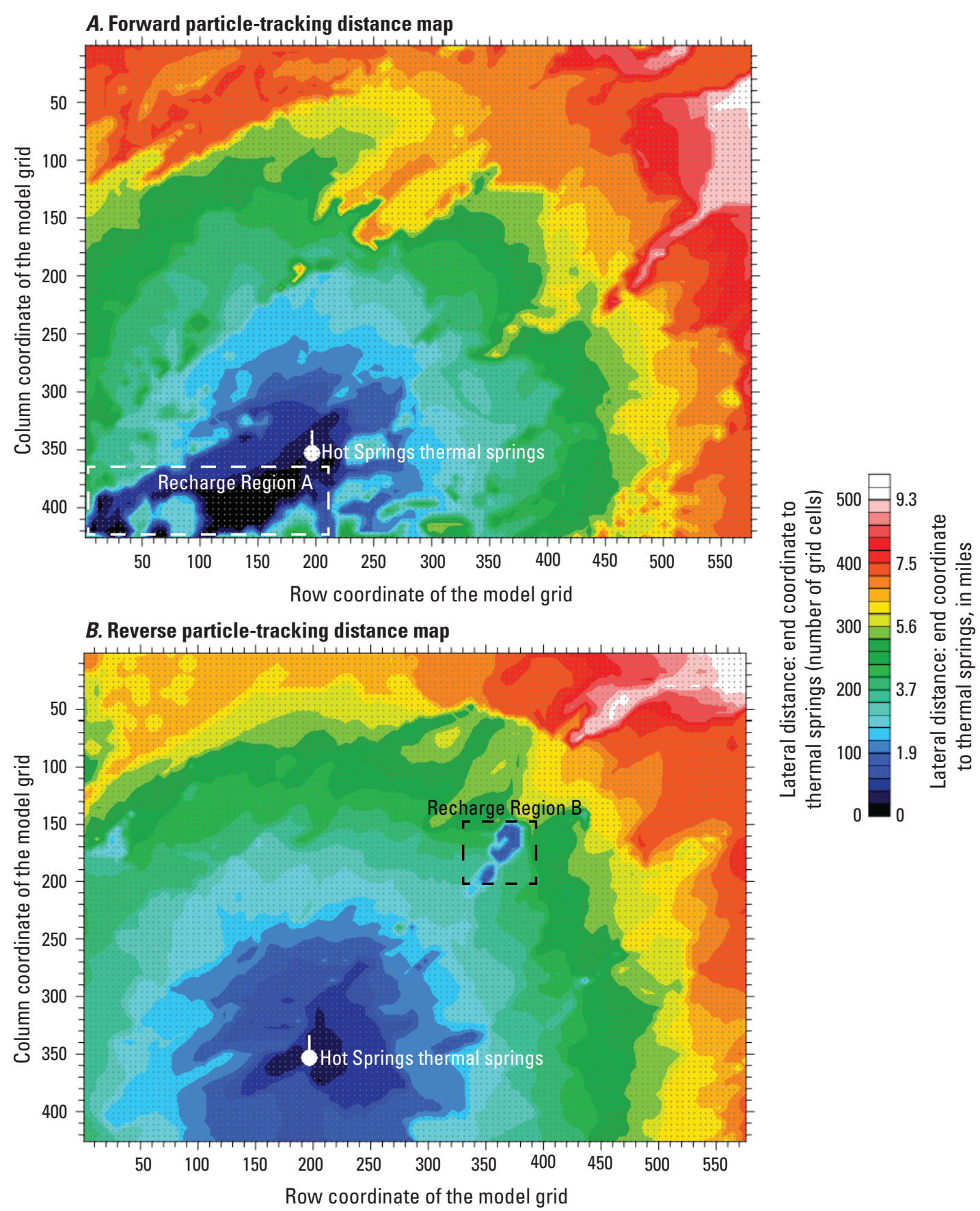

Figure 15. Forward and backward particle-tracking simulations produced from the calibrated MODFLOW groundwater-flow model. $A$. Forward particle-tracking map showing lateral distances between a particle's terminal path-line coordinate and the thermal springs, plotted the particle's origin coordinate. $B$. Backward particle-tracking map showing lateral distances between a particle's terminal path-line coordinate and the thermal springs, plotted at the particle's origin coordinate. The distance scale can be converted to units of feet by multiplying the discretization interval of 98.4 feet.

of the thermal springs corresponding to a location where the dominant lithology is the Bigfork Chert. Both recharge areas identified in figure 15 lie within the approximate recharge area delineated in figure 3 , and particle path lines originating from these areas end within 30-50 model-grid cells (or
0.6-0.9 mile) of the thermal springs. This distance may be somewhat misleading, however, because many of the plotted terminal distances in this area are nearly equal to the origin distance from the thermal springs, which suggests that many of the particles may not have traveled far in a lateral direction. 


\section{MODFLOW Model Simulations}

The starting heads and calibrated heads are summarized in table 6 by their median values in each rock formation and are illustrated in figures 13 and 16, respectively. In table 6, the minimum and maximum values for the median starting heads were in the vertical fault $(420 \mathrm{ft})$ and the Arkansas Novaculite $(763.7 \mathrm{ft})$, respectively, and the median starting heads in the rock formations of the framework were distributed between $523.4 \mathrm{ft}$ in the Stanley Shale and $763.7 \mathrm{ft}$ in the Arkansas Novaculite. The median values of the calibrated-model heads were distributed between the minimum in the Bigfork Chert $(805.2 \mathrm{ft})$ and the maximum in the Stanley Shale $(972.5 \mathrm{ft})$. The smallest median values of calibrated heads were in the Bigfork Chert (805.2 ft), Polk Creek-Missouri Mountain Shale (808.5 ft), and the Hot Springs Sandstone (812.6 ft), and the largest median values were in the Womble Shale $(951.8 \mathrm{ft})$ and the Stanley Shale (972.5 ft).

Predictive model simulations were performed with the calibrated MODFLOW model to investigate the potential effects of climate change and land use on the long-term variability of the daily mean spring flow at the thermal springs. The predictive simulations were implemented in steady state to predict new, steady-state spring-flow rates established by the groundwater-flow system in response to stresses in the form of varied recharge. Forty-three different PRMSsimulated recharge grids (table 7), each representative of the time period 2015-2099, were used in the predictive simulations as aerially distributed specified fluxes applied to layer 1 of the MODFLOW model grid (see Boundary Conditions in the MODFLOW Model). Thirty-four recharge arrays reflected recharge variability attributed to climate change, 3 reflected recharge variability attributed to changes in land use, and 6 reflected recharge variability attributed to a combination of climate and land-use change. Examples of the varied recharge for comparatively "wet" and "dry" conditions are shown in figure 11, and the results of the predictive simulations are summarized for the various recharge inputs in table 7 .

The stress period recharge predicted by the MODFLOW model (table 7) varied between the minimum of $1,977,382.3 \mathrm{ft}^{3} / \mathrm{d}$ (4.0 in/yr) and the maximum of 4,834,327.0 ft $3 / \mathrm{d}(9.7 \mathrm{in} / \mathrm{yr})$, around the mean of $3,937,813.8 \mathrm{ft}^{3} / \mathrm{d}(7.9 \mathrm{in} / \mathrm{yr})$. The recharge volume corresponding to the calibration simulation was $4,098,046.8 \mathrm{ft}^{3} / \mathrm{d}(8.2 \mathrm{in} / \mathrm{yr}$ for recharge applied to an area of $\left.78.4 \mathrm{mi}^{2}\right)$. The corresponding predicted spring flows at the thermal springs varied between the minimum of $47,799.2 \mathrm{ft}^{3} / \mathrm{d}$ (or about $0.5 \mathrm{ft}^{3} / \mathrm{s}$ ) and the maximum of $97,000.3 \mathrm{ft}^{3} / \mathrm{d}$ (or about $1.1 \mathrm{ft}^{3} / \mathrm{s}$ ), around the mean of $82,049.3 \mathrm{ft}^{3} / \mathrm{d}$ (or about $0.9 \mathrm{ft}^{3} / \mathrm{s}$ ). The mean value of all predicted thermal spring flows is about the same as the value of $85,102.7 \mathrm{ft}^{3} / \mathrm{d}$ (or about $1.0 \mathrm{ft}^{3} / \mathrm{s}$; table 5) quantified during the baseline calibration. River outflows varied between $1,929,582.8 \mathrm{ft}^{3} / \mathrm{d}$ and $4,737,327.0 \mathrm{ft}^{3} / \mathrm{d}$, around the mean of $3,855,764.5 \mathrm{ft}^{3} / \mathrm{d}$, and the river inflow was $0 \mathrm{ft}^{3} / \mathrm{d}$ for all simulations because the river stage was equated to the elevation of the riverbed. Mass balances were also computed as the differences between inputs and outputs of cumulative volumes of water for each predictive simulation (table 7). The inputs were in the form of the cumulative volumetric recharge through the top layer of the grid and cumulative fluxes through GHB and river cells. The outputs were in the form of cumulative head-dependent fluxes through river cells (or seepage loss from the aquifer units) and head-dependent fluxes at the thermal springs. The mass balances associated with each simulation varied between the minimum of $-0.9 \mathrm{ft}^{3} / \mathrm{d}$ and the maximum of $0.6 \mathrm{ft}^{3} / \mathrm{d}$, around the mean mass balance of $0 \mathrm{ft}^{3} / \mathrm{d}$.

The predicted relation between cumulative volumetric recharge supplied to the model and simulated daily spring flow at the thermal springs is shown in figure 17. The calibrated model simulated a linear relation between the volumetric recharge and the simulated daily mean spring flow with a corresponding $\mathrm{R}^{2}$ of 0.9987 . The relation is described by equation 16:

Table 6. Comparison of median values of starting heads and simulated heads by formation in the Hot Springs National Park and surrounding area, Arkansas.

[ft, foot]

\begin{tabular}{lcc}
\hline Formation (and geologic-map abbreviation) & Median starting head (ft) & Median calibrated head (ft) \\
\hline Polk Creek-Missouri Mountain Shale (Sm) & 621.1 & 808.5 \\
Womble Shale (Ow) & 584.4 & 951.8 \\
Arkansas Novaculite (MDa) & 763.7 & 814.9 \\
Stanley Shale (Ms) & 523.4 & 972.5 \\
Bigfork Chert (Obf) & 707.0 & 805.2 \\
Hot Springs Sandstone (Mshs) & 621.0 & 812.6 \\
Vertical fault & 420.0 & 840.2 \\
\hline Minimum & 420.0 & 805.2 \\
Maximum & 763.7 & 972.5 \\
\hline
\end{tabular}




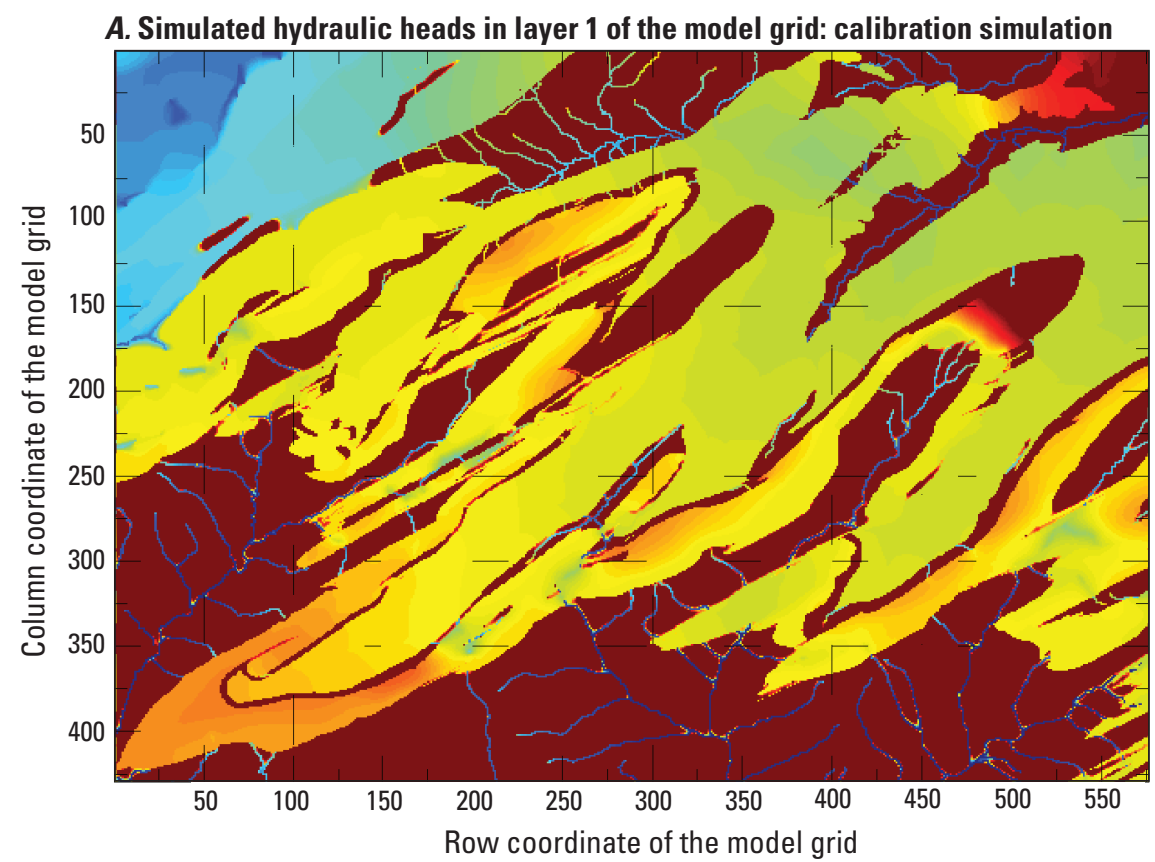

$B$. Simulated hydraulic heads beneath cross sections $A-A^{\prime}$ and $B-B^{\prime}$ (fig. 2):
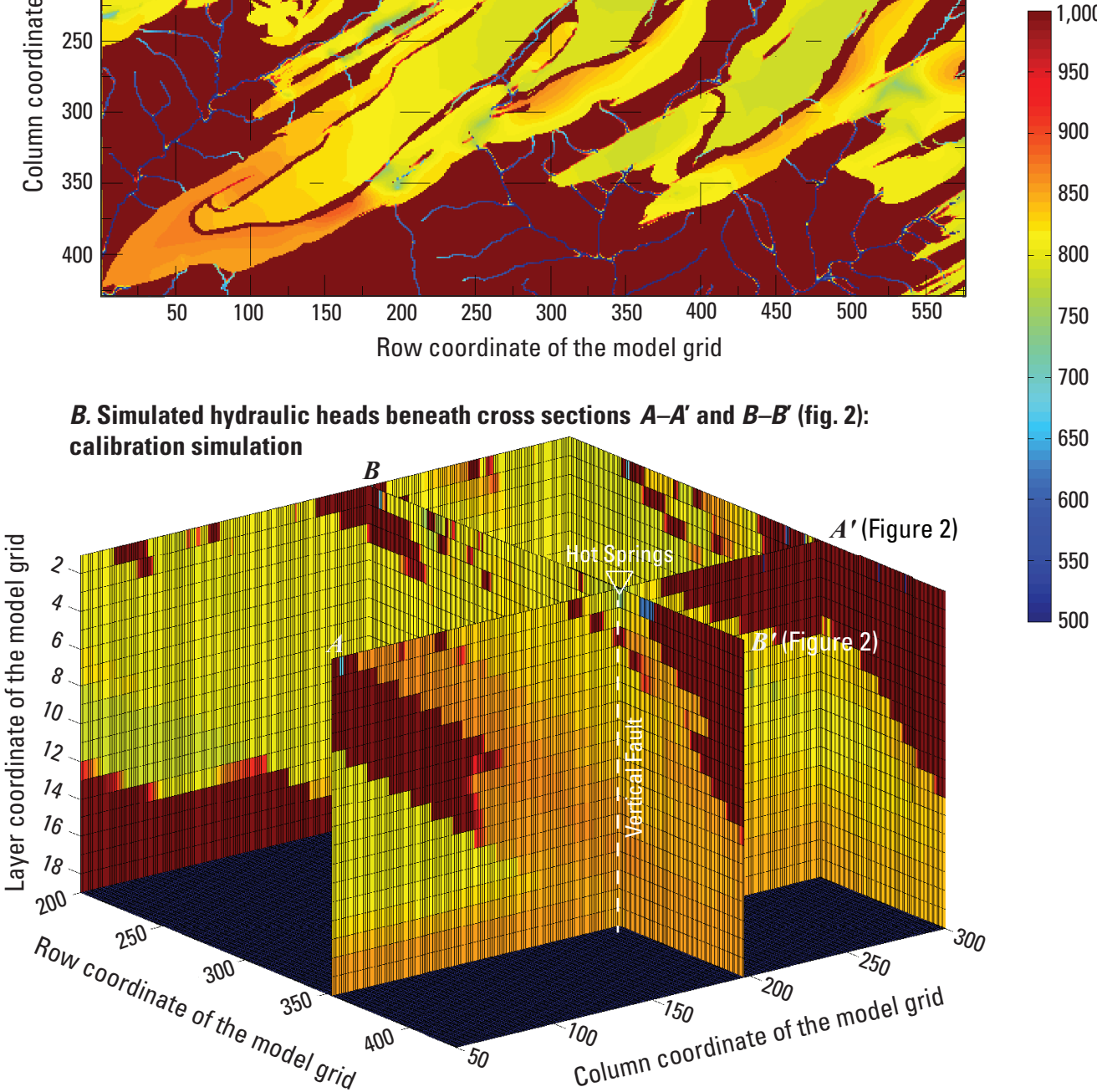

.

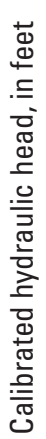

Figure 16. Simulated heads in the model grid corresponding to the calibration solution for the Hot Springs National Park and surrounding area, Arkansas. A. Simulated hydraulic heads in layer 1 of the model grid. $B$. Three-dimensional distribution of simulated hydraulic heads in the subsurface beneath cross sections $A-A^{\prime}$ and $B-B^{\prime}$ (fig. 2).

$$
Q_{s}=8,780.512 w+14,157.598
$$

where

$Q_{s} \quad$ is the simulated daily mean thermal spring flow, in cubic feet per day, and is the recharge rate, in inches per year.
This relation is oversimplified and uncertain because the true complexity of the natural groundwater-flow system cannot be fully accounted for by a mathematical model; however, for this study, it is considered a reasonable proxy for predicting the long-term variability of the daily mean spring flows given the current state of knowledge regarding the hydrogeologic framework and groundwater-flow system. 
Table 7. Summary of inputs and outputs of water and associated mass balances for Hot Springs National Park MODFLOW groundwater-flow model simulations using PRMS-simulated recharge grids as stresses to the groundwater-flow system.

[PRMS, Precipitation-Runoff Modeling System; $\mathrm{ft}^{3} / \mathrm{d}$, cubic foot per day]

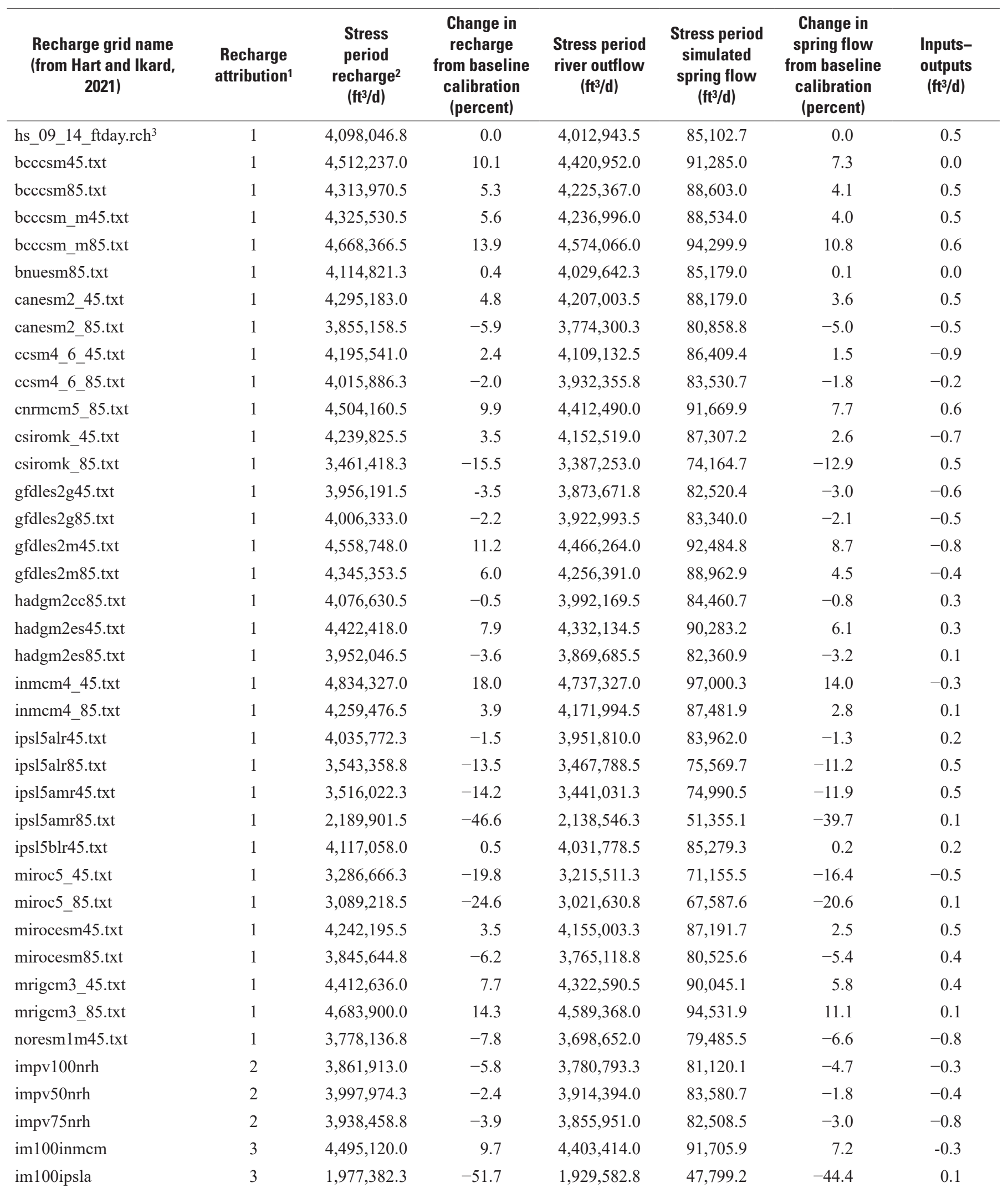


Table 7. Summary of inputs and outputs of water and associated mass balances for Hot Springs National Park MODFLOW groundwater-flow model simulations using PRMS-simulated recharge grids as stresses to the groundwater-flow system. - Continued

[PRMS, Precipitation-Runoff Modeling System; $\mathrm{ft}^{3} / \mathrm{d}$, cubic foot per day]

\begin{tabular}{|c|c|c|c|c|c|c|c|}
\hline $\begin{array}{c}\text { Recharge grid name } \\
\text { (from Hart and lkard, } \\
\text { 2021) }\end{array}$ & $\begin{array}{l}\text { Recharge } \\
\text { attribution }{ }^{1}\end{array}$ & $\begin{array}{c}\text { Stress } \\
\text { period } \\
\text { recharge }^{2} \\
\left(\mathrm{ft}^{3} / \mathrm{d}\right)\end{array}$ & $\begin{array}{c}\text { Change in } \\
\text { recharge } \\
\text { from baseline } \\
\text { calibration } \\
\text { (percent) }\end{array}$ & $\begin{array}{l}\text { Stress period } \\
\text { river outflow } \\
\left(\mathrm{ft}^{3} / \mathrm{d}\right)\end{array}$ & $\begin{array}{l}\text { Stress period } \\
\text { simulated } \\
\text { spring flow } \\
\left(\mathrm{ft}^{3} / \mathrm{d}\right)\end{array}$ & $\begin{array}{l}\text { Change in } \\
\text { spring flow } \\
\text { from baseline } \\
\text { calibration } \\
\text { (percent) }\end{array}$ & $\begin{array}{l}\text { Inputs- } \\
\text { outputs } \\
\left(\mathrm{ft}^{3} / \mathrm{d}\right)\end{array}$ \\
\hline imv50inmcm & 3 & $4,649,972.5$ & 13.5 & $4,555,509.0$ & $94,464.1$ & 11.0 & -0.6 \\
\hline imv50ipsla & 3 & $2,051,252.6$ & -49.9 & $2,001,938.8$ & $49,313.9$ & -42.1 & 0.0 \\
\hline imv75inmcm & 3 & $4,582,044.0$ & 11.8 & $4,488,784.5$ & $93,259.6$ & 9.6 & -0.1 \\
\hline imv75ipsla & 3 & $2,019,695.4$ & -50.7 & $1,971,025.4$ & $48,670.2$ & -42.8 & -0.2 \\
\hline Minimum & - & $1,977,382.3$ & -51.7 & $1,929,582.8$ & $47,799.2$ & -44.4 & -0.9 \\
\hline Maximum & - & $4,834,327.0$ & 18.0 & $4,737,327.0$ & $97,000.3$ & 14.0 & 0.6 \\
\hline Mean & - & $3,937,813.8$ & -3.9 & $3,855,764.5$ & $82,049.3$ & -3.6 & 0.0 \\
\hline Deviation & - & $716,866.5$ & 17.5 & $704,492.9$ & $12,376.7$ & 14.6 & 0.5 \\
\hline
\end{tabular}

${ }^{1}$ Recharge attribution definitions: 1 = Climate change, 2 = Land use varied, 3 = Combination of climate change and land use varied. For the climate-change scenarios, the naming corresponds to the Multivariate Adaptive Constructed Analogs (MACA) CMIP5 Statistically Downscaled Data for Coterminous USA (Program for Climate Model Diagnosis and Intercomparison, 2019). For a more detailed description of the climate scenarios, see https://pcmdi.llnl.gov/mips/ cmip5/availability.html. The land-use scenarios consisted of changing the hydrologic response units near the Highway 270 bypass to 50,75 , and 100 percent impervious.

${ }^{2}$ For recharge distributed over an area of 78.4 square miles in the MODFLOW groundwater-flow model.

${ }^{3}$ See figure 11A. This recharge grid was used in the calibration simulation for the MODFLOW groundwater-flow model.

The changes in simulated daily mean spring flow and stress period recharge were computed relative to the calibrated values. The largest reduction in simulated daily mean spring flow was a reduction of 44.4 percent relative to the calibrated thermal spring flow value of $85,102.7 \mathrm{ft}^{3} / \mathrm{d}$ (fig. 17), and the largest increase was an increase of 14.0 percent relative to the calibrated value. The mean change of simulated thermal spring flow corresponding to all predictive simulations summarized in table 7 was a 3.6-percent reduction.

When simulations representing climate change, landuse change, and combined climate and land-use change were considered independently, the average effect on thermal spring flow attributed to each was an overall reduction in spring flow relative to the calibrated value. With respect to climate-change exclusively, the mean change was a 1.3-percent reduction of the thermal spring flow that resulted from a 1.1-percent mean reduction of recharge. The largest reduction of simulated thermal spring flow attributed to climate change was a 39.7-percent reduction that resulted from a 46.6-percent reduction of recharge, and the largest simulated increase was a 14.0-percent increase that resulted from an 18.0-percent increase of recharge (table 7).

With respect to changes in land use, all three predictive simulations resulted in reductions of thermal spring flows (table 7), and the mean simulated change was a 3.2-percent reduction. The largest simulated change of thermal spring flow attributed to land-use change was a reduction of 4.7 percent that resulted from a 100-percent impervious land cover and a corresponding 5.8-percent reduction of recharge. The largest simulated reduction of simulated thermal spring flow was a 1.8-percent reduction that resulted from a 50-percent impervious land cover and a corresponding 2.4-percent reduction of recharge. A 3.0-percent reduction of thermal spring flow was predicted for a 75-percent impervious land cover and a corresponding 3.9-percent reduction of recharge.

The combined effects of climate and land-use changes resulted in the most extreme variability of thermal spring flows (table 7). For all six predictive simulations, the mean simulated change was a 16.9-percent reduction of thermal spring flow corresponding to a 19.6-percent mean reduction of recharge. The largest reduction of simulated thermal spring flow attributed to combined climate and land-use change was a 44.4-percent reduction that resulted from a 100-percent impervious land cover and a climate scenario characterized by an RCP of 8.5 (the most extreme climate-change scenario, see PRMS Model Climate Inputs), and a corresponding 51.7-percent reduction of recharge. The largest increase of simulated thermal spring flow was an 11.0-percent increase that resulted from a 50-percent impervious land cover and a climate scenario characterized by an RCP of 4.5 (a moderate climate-change scenario), and a corresponding 13.5-percent increase of recharge. 


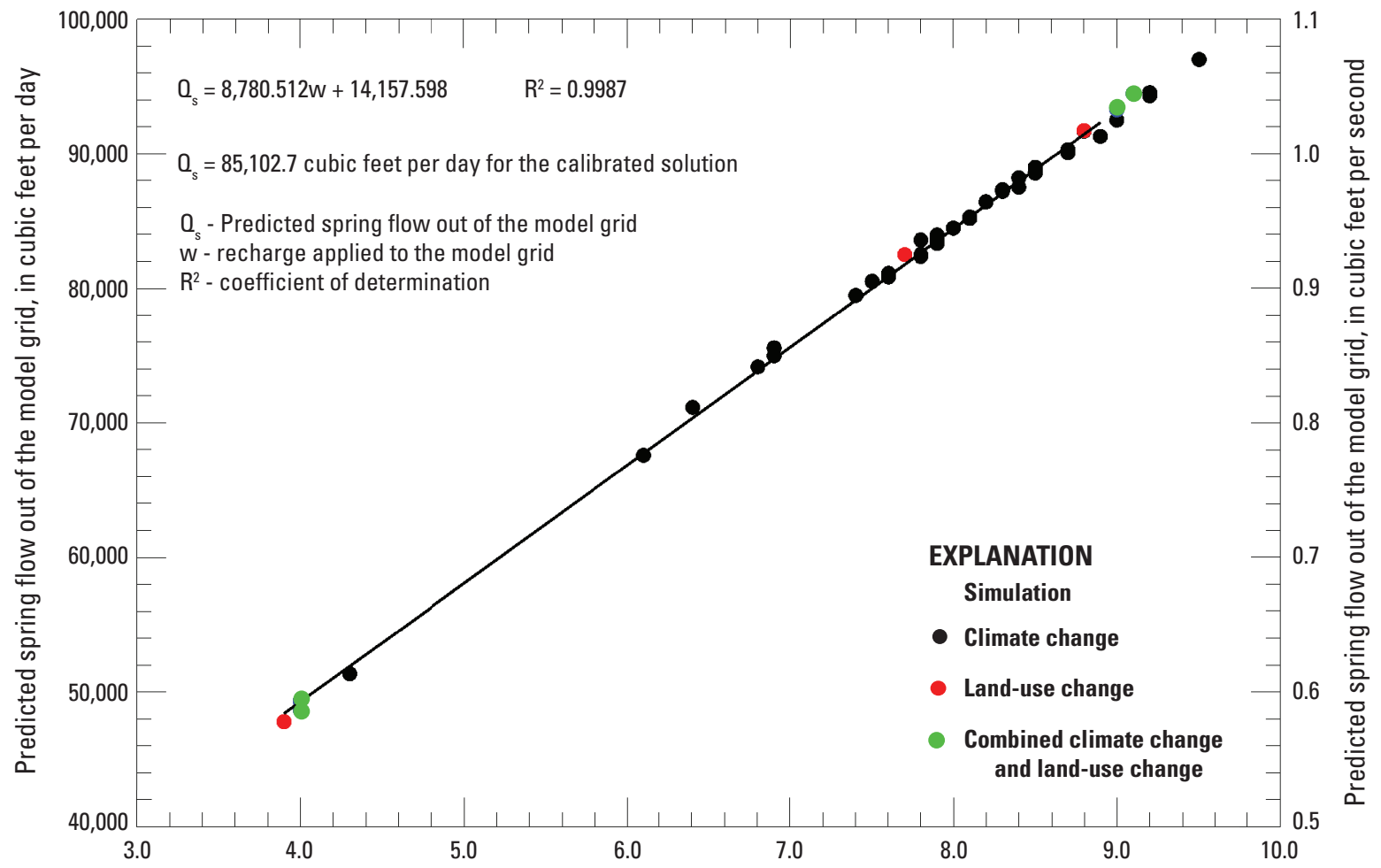

Recharge applied to model grid, in inches per year

Figure 17. Linear relation between recharge supplied to the groundwater-flow system and spring flows simulated by the calibrated model for the Hot Springs National Park study area, Arkansas.

\section{Model Assumptions and Limitations}

Assumptions are built into the PRMS and MODFLOW models described herein. These assumptions, in addition to the datasets used for model inputs, are prone to errors that may limit the accuracy of the individual model simulations and the predicted behaviors of the Hot Springs groundwaterflow system.

Foreseeable errors in the PRMS model include (1) errors attributed to inaccurate input climate data (historical and future climate datasets used for calibration and predictive simulations, respectively), (2) errors inherent within the streamflow data that are used to calibrate the PRMS model, (3) errors attributed to the subjective nature of the model calibration acceptance criteria, and (4) errors that arise from the inability to account for heterogeneity in the model parameters at a scale that is smaller than an HRU. With respect to historical and future climate data, Behnke and others (2016) demonstrated that while gridded input temperature data generally matched corresponding weather station records closely, the gridded input precipitation data generally did not compare as well to the weather station records. With respect to the calibration streamflows, the PRMS model was calibrated to daily mean streamflow at one single streamgage location, which was used as a representative station for the entire PRMS model area. With respect to heterogeneity, the SSURGO data used to develop certain hydrologic parameters of the PRMS model were lumped over an entire HRU, and the properties of each HRU were assumed to be homogeneous and isotropic. As a result, detailed small-scale heterogeneity in the spatial distribution of these parameters was not accounted for.

Errors associated with the MODFLOW model may arise because the model does not simulate heat transport or densitydependent groundwater flow even though both are dominant physical processes occurring in the groundwater-flow system. Furthermore, the MODFLOW model domain encompasses about $86 \mathrm{mi}^{2}$ of surface area to depths greater than $9,000 \mathrm{ft}$, and the hydrogeologic framework within this discretized volume is complex and uncertain. In the presence of this framework uncertainty, the MODFLOW model was only manually calibrated to one single target (daily mean thermal spring flows at the Hot Springs collection system). Without additional calibration targets to constrain the solution, including heads in various layers of the model grid, the MODFLOW model may not accurately reflect the distribution of heads and flows in the subsurface and therefore may not accurately represent the groundwater-flow system for any predictive simulations.

The predicted relation between recharge and thermal spring flow is uncertain because the true complexity of the groundwater-flow system cannot be fully accounted for by the 
MODFLOW model. The uncertainty of this predicted relation is attributed to the fact that the parameter values and boundary conditions used in the MODFLOW model are uncertain. Specifically,

1. The parameters were calibrated manually as opposed to automatically, and although they are comparable to values reported in the literature, the manual calibration imparts a degree of subjectivity into the acceptance of the calibrated parameter values.

2. Similar to the PRMS model parameters, the MODFLOW model parameters were assumed homogeneous and isotropic over the entire volume of the model-grid cells to which they were assigned, but in reality they are heterogeneous and typically anisotropic and scale-dependent.

3. Parameter uncertainty was not quantified, and parameter correlation was assumed negligible.

4. The discretization of the framework was assumed to be sufficient for capturing groundwater-flow processes at a representative scale of interest; however, groundwaterflow patterns over distances smaller than a model-grid cell cannot be resolved by the MODFLOW model.

5. The base of the model was assumed to be impermeable, and the external GHB boundaries around the perimeter of the model grid were assumed to be located an adequate distance from the primary area of interest beneath Hot Springs National Park (delineated by cross sections $A-A^{\prime}$ and $B-B^{\prime}$, fig. 2) such that the boundary condition did not substantially influence the simulated heads and flows within that area.

6. The heads in GHB cells were calculated from a conceptual model that assumed frictional head losses along the flow path were negligible.

7. The locations and sizes of the recharge areas that are present in the model framework were affected by the hydrogeologic framework, the assigned parameter values, and by the head-dependent boundary conditions in river and GHB grid cells such that the accuracy of the particle-tracking simulations is limited by the accuracy of the MODFLOW model.

8. The MODFLOW model was run in steady state and was not calibrated to transient conditions; therefore, the timing and magnitude of the predicted system behavior could be in error.

\section{Summary}

This investigation addressed two outstanding questions pertaining to the groundwater-flow system at Hot Springs National Park, Arkansas. First, where is the origin of the recharge to the thermal springs? Second, what are the potential effects of climate and land-use changes on the long-term variability of the spring-flow rates at the thermal springs? A coupled surface-water and groundwater-flow model was developed by the U.S. Geological Survey, in cooperation with the National Park Service, to address these questions and to serve as an investigative tool to support continued research. This coupled model was the combination of a watershed model constructed in the Precipitation-Runoff Modeling System (PRMS) and a three-dimensional groundwater-flow model constructed in MODFLOW-2005.

The PRMS model was calibrated to historical daily mean streamflow data for the period 1980-2014 and forecasted aerially-distributed recharge in Hot Springs National Park and the surrounding region for the period 2015-2099. Fortythree PRMS simulations were performed, and each produced a different spatial distribution of recharge attributed to either climate change, land-use change, or a combination of climate and land-use change. Thirty-four PRMS simulations reflected recharge variability attributed exclusively to climate change, three reflected variability attributed exclusively to land use, and 6 reflected variability attributed to a combination of climate and land-use change.

The MODFLOW groundwater-flow model included six rock formations and one vertical fault in the discretized hydrogeologic framework, and was manually calibrated to the mean daily thermal spring flow of 88,000 cubic feet per day $\left(\mathrm{ft}^{3} / \mathrm{d}\right.$ ) (or about 1.0 cubic feet per second $\left[\mathrm{ft}^{3} / \mathrm{s}\right]$ ) at the thermal springs collection system corresponding to a 12-year period of measurement (1990-1995 and 1998-2005). The calibrated MODFLOW model simulated groundwater flow and discharge at the thermal springs in Hot Springs National Park by using the PRMS-simulated recharge as a boundary condition in the steady-state solution of the groundwater-flow equation.

To address the question about the origin of the recharge to the springs, forward and backward particle-tracking maps were developed. These maps indicated that the most prevalent areas of recharge in the discretized hydrogeologic framework used in this study were within 30-50 model-grid cells (about $0.6-0.9$ mile) of the thermal springs. Forward particle tracking indicated a recharge area southwest of the thermal springs, and this recharge area corresponded to a location where the predominant lithologies are the Arkansas Novaculite, Hot Springs Sandstone, and Bigfork Chert. Backward particle tracking indicated a second localized area of recharge to the northeast of the thermal springs, and this recharge area corresponded to a location where the dominant lithology is the Bigfork Chert. The MODFLOW model indicated that the most probable recharge formations are the Arkansas Novaculite, Bigfork Chert, and Hot Springs Sandstone. This indication was also supported by sensitivity analysis performed on the manually calibrated MODFLOW model. The sensitivity analysis indicated that simulated thermal spring flows were particularly sensitive to the horizontal and vertical hydraulic 
conductivities of the Arkansas Novaculite, and moderately sensitive to the horizontal and vertical hydraulic conductivities of the Bigfork Chert.

The simulated effects of climate and land-use changes on the long-term variability of the spring-flow rates at the thermal springs generally resulted in reductions of thermal spring flow attributed to urban development and more extreme climates characterized by elevated mean surface air temperatures. The MODFLOW groundwater-flow model predicted a linear relation between the thermal spring discharge and the cumulative recharge volume applied to the hydrogeologic framework, and the positive slope of the predicted relation between recharge and simulated thermal spring flow indicates that more extreme precipitation events that supply more recharge may in fact increase the thermal spring-flow rates. The spring flows simulated at the thermal springs with the MODFLOW model varied between the minimum of $47,799.2 \mathrm{ft}^{3} / \mathrm{d}$ (or about $0.5 \mathrm{ft}^{3} / \mathrm{s}$ ) and the maximum of $97,000.3 \mathrm{ft}^{3} / \mathrm{d}$ (or about $1.1 \mathrm{ft}^{3} / \mathrm{s}$ ), around the mean of $82,049.3 \mathrm{ft}^{3} / \mathrm{d}$ (or about $0.9 \mathrm{ft}^{3} / \mathrm{s}$ ), which was about the same as the calibrated thermal spring flow $\left(85,102.7 \mathrm{ft}^{3} / \mathrm{d}\right.$, or about $1.0 \mathrm{ft}^{3} / \mathrm{s}$ ). These simulated thermal spring flows correspond to recharge rates of 4.0 inches per year (in/yr), $9.7 \mathrm{in} / \mathrm{yr}$, and $7.9 \mathrm{in} / \mathrm{yr}$, respectively. The largest simulated reduction of daily mean spring flow was a 44.4-percent reduction relative to the calibrated thermal spring flow, and the largest simulated increase was a 14.0-percent increase relative to the calibrated thermal spring flow. The mean simulated change of thermal spring flow corresponding to all predictive simulations performed in this investigation was a 3.6-percent reduction relative to the baseline calibration value.

When simulations representing climate change, landuse change, and combined climate and land-use change were considered independently, the average effect on thermal spring flow attributed to each was an overall reduction relative to the calibrated value. With respect to climate-change simulations exclusively, the mean change of the simulated thermal spring flow was a 1.3-percent reduction that resulted from a 1.1-percent mean reduction of recharge. A 39.7-percent reduction of the thermal spring flow was simulated from a corresponding 46.6-percent reduction of recharge, and a 14.0-percent increase of thermal spring flow was simulated from a corresponding 18.0-percent increase of recharge.

With respect to land-use changes exclusively, all predictive simulations resulted in reductions of thermal spring flows, and the mean simulated change was a 3.2-percent reduction. The largest reduction of thermal spring flow attributed to land-use change was a 4.7-percent reduction that resulted from a 100-percent impervious land cover and a corresponding 5.8-percent reduction of recharge. The smallest simulated reduction of thermal spring flow was a 1.8-percent reduction that resulted from a 50-percent impervious land cover and a corresponding 2.4-percent reduction of recharge. A simulated 3.0-percent reduction of thermal spring flow resulted from a 75 -percent impervious land cover and corresponding 3.9-percent reduction of recharge.
The combination of climate and land-use changes resulted in the most extreme variability of simulated thermal spring flows. The mean simulated change was a 16.7-percent reduction of thermal spring flow corresponding to a 19.6-percent mean reduction of recharge. The largest reduction of simulated thermal spring flow attributed to combined climate and land-use change was a 43.8-percent reduction that resulted from a 100-percent impervious land cover and a climate scenario characterized by an RCP of 8.5 (the most extreme climate-change scenario), and a corresponding 51.7-percent reduction of recharge. The largest increase of simulated thermal spring flow was an 11.0-percent increase that resulted from a 50-percent impervious land cover and a climate scenario characterized by an RCP of 4.5 (a moderate climate-change scenario), and a corresponding 13.5-percent increase of recharge.

The hot springs recharge area lies largely outside of the Hot Springs National Park boundary adding a challenge to management of the resource. Anticipated land-use and climate changes raise important questions about how development in the hot springs recharge area will impact the thermal spring flow and temperature of the thermal springs in the future. The most important aspect of this investigation was therefore to provide Hot Springs National Park with a research tool to produce unbiased, scientifically defensible simulations of the thermal spring flow for a variety of land-use and climate change scenarios. The PRMS model and coupled MODFLOW groundwater-flow model described in this report were developed for the National Park Service to provide research tools for continued study of the thermal springs groundwater-flow system of Hot Springs National Park. This report described the development, calibration, and use of the PRMS and MODFLOW models, with an emphasis on generating a conceptual model of groundwater flow through the deep flow system at Hot Springs National Park more so than developing a true calibration dataset. In this report, the MODFLOW groundwaterflow model was manually calibrated to a single calibration target-daily mean spring flows of 88,000 cubic feet per day quantified from 12-year period of record (1990-1995 and 1998-2005). Future improvements to the groundwater-flow model, could include the following modifications: (1) development of a calibration dataset comprised of a sufficient number of spatially distributed well-heads that represent different layers of the model grid, additional streamflow observations, and updated thermal spring flow records that combine historical and current observations, (2) perform automated calibration to the head, streamflow, and spring flow observations using a suitable inverse modeling code, and (3) convert the groundwater-flow model from a MODFLOW 2005 model to a SEAWAT model (Langevin and others, 2007) to account for the effects of geothermal gradient and total dissolved solids on groundwater density in the numerical solution of the groundwater-flow equation. 


\section{References Cited}

Abatzoglou, J.T., 2013, Development of gridded surface meteorological data for ecological applications and modelling: International Journal of Climatology, v. 33, no. 1, p. 121-131, accessed July 22, 2019, at https://doi.org/ $10.1002 /$ joc.3413.

Abatzoglou, J.T., and Brown, T.J., 2012, A comparison of statistical downscaling methods suited for wildfire applications: International Journal of Climatology, v. 32, no. 5, p. 772-780, accessed July 22, 2019, at https://doi.org/ 10.1002/joc.2312.

Albin, D.R., 1965, Water-resources reconnaissance of the Ouachita Mountains, Arkansas: U.S. Geological Survey Water-Supply Paper 1809-J, 14 p.

Anderson, M.P., and Woessner, W.W., 2002, Applied groundwater modeling-Simulation of flow and advective transport: San Diego, Calif., Elsevier, 381 p.

Arkansas Geological Survey, 2016, Stratigraphic summary of the Arkansas River Valley and Ouachita Mountains: Arkansas Geological Survey, accessed February 1, 2016, at http://www.geology.ar.gov/geology/strat_arkvalley_ ouachita.htm.

Arndt, R.H., and Stroud, R.B., 1953, Thrust faulting near the Hot Springs, Hot Springs National Park, Arkansas, appendix 3, in Arndt, R.H., and Damon, P.E., Radioactivity of thermal waters and its relationship to the geology and geochemistry of uranium: University of Arkansas Institute of Science and Technology Annual Progress Report to the U.S. Atomic Energy Commission, 28 p.

Bedinger, M.S., Pearson, F.J., Reed, J.R., Sniegocki, R.T., and Stone, C.G., 1979, The waters of Hot Springs National Park, Arkansas-Their nature and origin: U.S. Geological Survey Professional Paper 1044-C, 33 p. [Also available at https://doi.org/10.2172/6718099.]

Behnke, R., Vavrus, S., Allstadt, A., Albright, T., Thogmartin, W.E., and Radeloff, V.C., 2016, Evaluation of downscaled, gridded climate data for the conterminous United States: Ecological Applications, v. 26, no. 5, p. 1338-1351. [Also available at https://doi.org/10.1002/15-1061.]

Bell, R.W., and Hays, P.D., 2007, Influence of locally derived recharge on the water quality and temperature of springs in Hot Springs National Park, Arkansas: U.S. Geological Survey Scientific Investigations Report 2007-5004, 46 p. [Also available at https://doi.org/10.3133/sir20075004.]
Blodgett, D., Booth, N., Kunicki, T., Walker, J., and Lucido, J., 2012, Description of the U.S. Geological Survey Geo Data Portal Data Integration Framework: IEEE Journal of Selected Topics in Applied Earth Observations and Remote Sensing, v. 5, no. 6, p. 1687-1691. [Also available at https://doi.org/10.1109/JSTARS.2012.2196759.]

Blodgett, D.L., Booth, N.L., Kunicki, T.C., Walker, J.I., and Viger, R.J., 2011, Description and testing of the Geo Data Portal-A data integration framework and web processing services for environmental science collaboration: U.S. Geological Survey Open-File Report 2011-1157, 9 p. [Also available at https://doi.org/10.3133/ofr20111157.]

Bryan, K., 1922, The hot water supply of the Hot Springs, Arkansas: The Journal of Geology, v. 30, no. 6, p. 425-449. [Also available at https://doi.org/10.1086/622931.]

Bryan, K., 1924, The hot springs of Arkansas: The Journal of Geology, v. 32, no. 6, p. 449-459. [Also available at https://doi.org/10.1086/623124.]

Carter, L.M., Jones, J.W., Berry, L., Burkett, V., Murley, J.F., Obeysekera, J., Schramm, P.J., and Wear, D., 2014, Southeast and the Caribbean, chapter 17, in Melillo, J.M., Richmond, T.C., and Yohe, G.W., eds., Climate change impacts in the United States-The Third National Climate Assessment: U.S. Global Change Research Program, p. 396-417, accessed July 22, 2019, at https://doi.org/ 10.7930/J0NP22CB.

Domenico, P.A., and Schwartz, F.W., 1990, Physical and chemical hydrogeology: New York, John Wiley and Sons, $824 \mathrm{p}$.

Fenneman, N.M., and Johnson, D.W., 1946, Physiographic divisions of the conterminous U.S.: U.S. Geological Survey.

Fournier, R.O., and Rowe, J.J., 1966, Estimation of underground temperatures from the silica content of water from hot springs and wet-steam wells: American Journal of Science, v. 264, no. 9, p. 685-697. [Also available at https://doi.org/10.2475/ajs.264.9.685.]

Harbaugh, A.W., 2005, MODFLOW-2005, the U.S. Geological Survey modular ground-water model-The ground-water flow process: U.S. Geological Survey Techniques and Methods 6-A16.

Harbaugh, A.W., Banta, E.R., Hill, M.C., and McDonald, M.G., 2000, MODFLOW-2000, the U.S. Geological Survey modular ground-water model-User guide to modularization concepts and the ground-water flow process: U.S. Geological Survey Open-File Report 00-92, 121 p. [Also available at https://doi.org/10.3133/ofr200092.] 
Hart, R.M., and Ikard, S.J., 2021, Model inputs and outputs for simulating and predicting the effects of climate and landuse changes on thermal springs recharge- - A system-based coupled surface-water and groundwater-flow model for Hot Springs National Park, Arkansas: U.S. Geological Survey data release, https://doi.org/10.5066/P9SBJVVL.

Hill, M.C., and Tiedeman, C.R., 2007, Effective groundwater model calibration - With analysis of data, sensitivities, predictions, and uncertainty: Hoboken, New Jersey, Wiley-Interscience, $455 \mathrm{p}$. [Also available at https://doi.org/ 10.1002/0470041080.]

Homer, C., Dewitz, J., Fry, J., Coan, M., Hossain, N., Larson, C., Herold, N., McKerrow, A., VanDriel, J.N., and Wickham, J., 2007, Completion of the 2001 National Land Cover Database for the conterminous United States: Photogrammetric Engineering and Remote Sensing, v. 73, no. 4, p. 337-341.

Johnson, T.C., and Hanson, W.D., 2011, Geologic map of the Hot Springs North, Hot Springs South, Fountain Lake, and Lake Catherine Quadrangles, Garland, Hot Spring, and Saline Counties, Arkansas: Digital Geologic Map DGM-HSR-003, accessed July 22, 2019, at https://www.g eology.arkansas.gov/docs/pdf/maps-and-data/geologic maps/hot-springs-national-park-geologic-map-2011.pdf.

Jyrkama, M.I., Sykes, J.F., and Normani, S.D., 2002, Recharge estimation for transient ground water modeling: Groundwater, v. 40, no. 6, p. 638-648. [Also available at https://doi.org/10.1111/j.1745-6584.2002.tb02550.x.]

Kresse, T.M., and Hays, P.D., 2009, Geochemistry, comparative analysis, and physical and chemical characteristics of the thermal waters east of Hot Springs National Park, Arkansas, 2006-2009: U.S. Geological Survey Scientific Investigations Report 2009-5263, 48 p.

Lacombe, G., Douangsavanh, S., Vongphachanh, S., and Pavelic, P., 2017, Regional assessment of groundwater recharge in the lower Mekong Basin: Hydrology, v. 4, no. 60,18 p. [Also available at https://doi.org/10.3390/ hydrology4040060.]

Langevin, C.D., Thorne, D.T., Jr., Dausman, A.M., Sukop, M.C., and Guo, W., 2007, SEAWAT Version 4-A computer program for simulation of multi-species solute and heat transport: U.S. Geological Survey Techniques and Methods, book 6, chap. A22, 39 p.

Markstrom, S.L., Regan, R.S., Hay, L.E., Viger, R.J., Webb, R.M.T., Payn, R.A., and LaFontaine, J.H., 2015, PRMS-IV, the Precipitation-Runoff Modeling System, version 4: U.S. Geological Survey Techniques and Methods, book 6, chap. B7, 158 p., accessed July 22, 2019, at https://dx.doi.org/ 10.3133/tm6B7.
McDonald, M.G., and Harbaugh, A.W., 1988, A modular three-dimensional finite-difference ground-water flow model: U.S. Geological Survey Techniques of Water Resources Investigations, book 6, chap. A1, 586 p., accessed July 22, 2019, at https://pubs.er.usgs.gov/ publication/twri06A1.

McFarland, J.D., 2004, Stratigraphic summary of Arkansas: Arkansas Geologic Commission, Information Circular 36, IC-36, 38 p, accessed December 2, 2020, at https://www. geology.arkansas.gov/docs/pdf/publication/informationcirculars/IC-36.pdf.

Moriasi, D.N., Arnold, J.G., Van Liew, M.W., Bingner, R.L., Harmel, R.D., and Veith, T.L., 2007, Model evaluation guidelines for systematic quantification of accuracy in watershed simulations: American Society of Agricultural and Biological Engineers, v. 50, no. 3, p. 885-900.

Munson, B.R., Young, D.F., and Okiishi, T.H., 2006, Fundamentals of fluid mechanics (5th ed.): Hoboken, New Jersey, John Wiley and Sons, Inc., 769 p.

Nottmeier, A.M., and Hays, P.D., 2019, Potentiometric surface of groundwater-level altitudes near the planned Highway 270 bypass, east of Hot Springs, Arkansas, July-August 2017: U.S. Geological Survey Scientific Investigations Map 3444, 13 p., 1 sheet, accessed May 27, 2020, at https://doi.org/10.3133/sim3444.

Pachauri, R.K., and Meyer, L.A., eds., 2014, Climate change 2014 synthesis report: Geneva, Switzerland, International Panel on Climate Change, $151 \mathrm{p}$.

Petersen, J.C., and Mott, D.N., 2002, Hot Springs National Park, Arkansas water resources scoping report: National Park Service Technical Report NPS/NRWRD/ NRTR-2002/301, 26 p.

Pollock, D.W., 2012, User guide for MODPATH Version 6-A particle-tracking model for MODFLOW: U.S. Geological Survey Techniques and Methods, book 6, chap. A41, 59 p.

Program for Climate Model Diagnosis and Intercomparison, 2019, CMIP5 - Data access-Availability, accessed May 27, 2020, at https://pcmdi.llnl.gov/mips/cmip5/ availability.html.

Purdue, A.H., 1910, The collecting area of the waters of the hot springs, Hot Springs, Arkansas: The Journal of Geology, v. 18, no. 3, p. 279-285. [Also available at https://doi.org/ 10.1086/621726.]

Reilly, T.E., and Harbaugh, A.W., 2004, Guidelines for evaluating groundwater flow models: U.S. Geological Survey Scientific Investigations Report 2004-5038, 37 p. 
Rutledge, A.T., 1998, Computer programs for describing the recession of ground-water discharge and for estimating mean ground-water recharge and discharge from streamflow data-Update: U.S. Geological Survey Water-Resources Investigations Report 98-4148, 43 p., accessed July 22, 2019, at https://pubs.usgs.gov/wri/wri984148/.

Rutledge, A.T., 2000, Considerations for use of the RORA program to estimate ground-water recharge from streamflow records: U.S. Geological Survey Open-File Report 00-156, 44 p., accessed July 22, 2019, at https://pubs.usgs.gov/of/ 2000/ofr00-156/.

Saxton, K.E., and Rawls, W.J., 2006, Soil water characteristic estimates by texture and organic matter for hydrologic solutions: Soil Science Society of America Journal, v. 70, no. 5, p. 1569-1578. [Also available at https://doi.org/10.2136/ sssaj2005.0117.]

Thornthwaite, C.W., and Mather, J.R., 1955, The water balance: Publications in Climatology, v. 8, no. 1, p. 1-104.

Thornthwaite, C.W., and Mather, J.R., 1957, Instructions and tables for computing potential evapotranspiration and the water balance: Publications in Climatology, v. 10, no. 3, p. 185-311.

U.S. Department of Agriculture, 2019a, Official soil series descriptions: U.S. Department of Agriculture, Natural Resources Conservation Service, Soil Survey Division, accessed July 22, 2019, at https:/www.nrcs.usda.gov/wps/ $\mathrm{portal} / \mathrm{nrcs} / \mathrm{detail} /$ soils/survey/geo/?cid=nrcs142p2_053587.

U.S. Department of Agriculture, 2019b, Soil survey geographic database (SSURGO): U.S. Department of Agriculture, Natural Resources Conservation Service, accessed July 22, 2019, at https://websoilsurvey. nrcs.usda.gov/.

U.S. Environmental Protection Agency, 2017, Hydrologic Evaluation of Landfill Performance (HELP) model, accessed July 22, 2019, at https://www.epa.gov/landresearch/hydrologic-evaluation-landfill-performancehelp-model.

U.S. Geological Survey [USGS], 2019a, 3D Elevation Program (3DEP), accessed July 22, 2019, at https:/www.usgs.gov/corescience-systems/ngp/3dep/about-3dep-products-services.
U.S. Geological Survey [USGS], 2019b, National hydrography dataset, accessed July 22, 2019, at https://www .usgs.gov/core-science-systems/ngp/national-hydrography.

U.S. Geological Survey [USGS], 2019c, USGS water data for the Nation: U.S. Geological Survey National Water Information System database, accessed July 22, 2019, at https://doi.org/10.5066/F7P55KJN.

Viger, R.J., 2014, Preliminary spatial parameters for PRMS based on the Geospatial Fabric, NLCD2001 and SSURGO: U.S. Geological Survey, accessed July 22, 2019, at https://dx.doi.org/doi:10.5066/F7WM1BF7.

Viger, R.J., and Bock, A., 2014, GIS features of the Geospatial Fabric for National Hydrologic Modeling: U.S. Geological Survey, accessed July 22, 2019, at https://dx.doi.org/ doi:10.5066/F7542KMD.

Wang, H.F., and Anderson, M.P., 1982, Introduction to groundwater modeling: San Diego, California, Academic Press, Inc., 237 p.

Weed, W.H., 1902, Geological sketch of Hot Springs, Arkansas: U.S. 57th Congress, 1st Session, Senate document 282, p. 79-94.

Westenbroek, S.M., Kelson, V.A., Dripps, W.R., Hunt, R.J., and Bradbury, K.R., 2010, SWB-A modified Thornthwaite-Mather Soil-Water-Balance code for estimating groundwater recharge: U.S. Geological Survey Techniques and Methods, book 6, chap. A31, 72 p.

World Climate Research Programme, 2020, WCRP Coupled Model Intercomparison Project (CMIP), accessed January 27, 2020, at https:/www.wcrp-climate.org/ wgcm-cmip.

Yeatts, D.S., 2006, Characteristics of thermal springs and the shallow ground-water system at Hot Springs National Park, Arkansas: U.S. Geological Survey Scientific Investigations Report 2006-5001, 42 p. [Also available at https://doi.org/ 10.3133/sir20065001.]

Zhang, Z., and Nemcik, J., 2013, Friction factor of water flow through rough rock fractures: Rock Mechanics and Rock Engineering, v. 46, no. 5, p. 1125-1134. [Also available at https://doi.org/10.1007/s00603-012-0328-9.] 
For more information about this publication, contact Director, Lower Mississippi-Gulf Water Science Center U.S. Geological Survey

640 Grassmere Park, Suite 100

Nashville, TN 37211

For additional information, visit https://www.usgs.gov/centers/mg-water/

Publishing support provided by Lafayette Publishing Service Center

Back cover. Photograph showing Hot Springs, Arkansas. 
$\lim ^{2}+2+5$

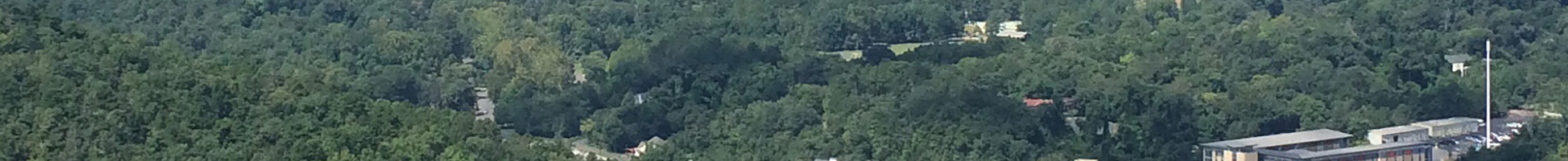

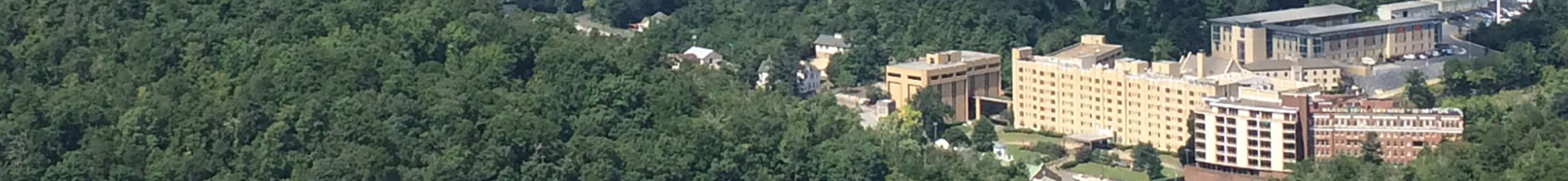

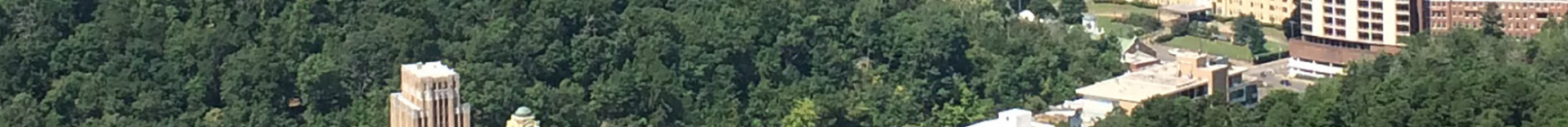

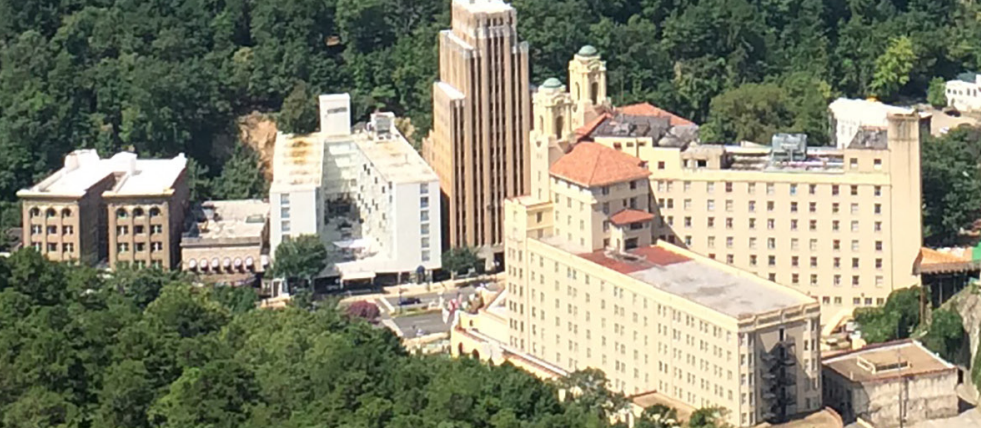

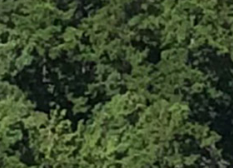
a. - 5

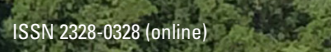

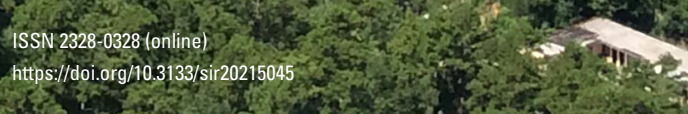

